\title{
Preparação e Caracterização de Compósitos de Poli (cloreto de vinila) Reforçados com Fibras de Sisal
}

\author{
Gilson Silvestre Martins
}

Dissertação apresentada à Área Interunidades em Ciência e Engenharia de Materiais, da Universidade de São Paulo, para obtenção do título de Mestre em Ciências e Engenharia de Materiais.

Orientador: Prof. Dr. Luiz Henrique Capparelli Mattoso 
Martins, Gilson Silvestre

"Preparação e Caracterização de Compósitos de Poli (cloreto de vinila)

Reforçados com Fibras de Sisal"

Gilson Silvestre Martins - São Carlos, 2003

Dissertação (Mestrado) - Área de Interunidades em Ciência e Engenharia de Materiais da Universidade de São Paulo,

2003 - Páginas: 75

Orientador: Prof. Dr. Luiz Henrique Capparelli Mattoso

1. Compósitos; 2. Sisal; 3. Poli (cloreto de vinila).

I. Título 
UNIVERSIDADE DE SÃO PAULO

Ciência e Engenharia de Materiais

Caixa Postal 369 - CEP 13560-970 - São Carlos-SP - Bras

Tel: (0xx16) 2739589/ Fax: (Oxx16) 273977

MEMBROS DA COMISSÃO JULGADORA DA DISSERTAÇÃO DE MESTRADO DE GILSON SILVESTRE MARTINS, APRESENTADA À ÁREA INTERUNIDADES CIÊNCIA E ENGENHARIA DE MATERIAIS, UNIVERSIDADE DE SÃO PAULO, EM 27/05/2003.

COMISSÃO JULGADORA:

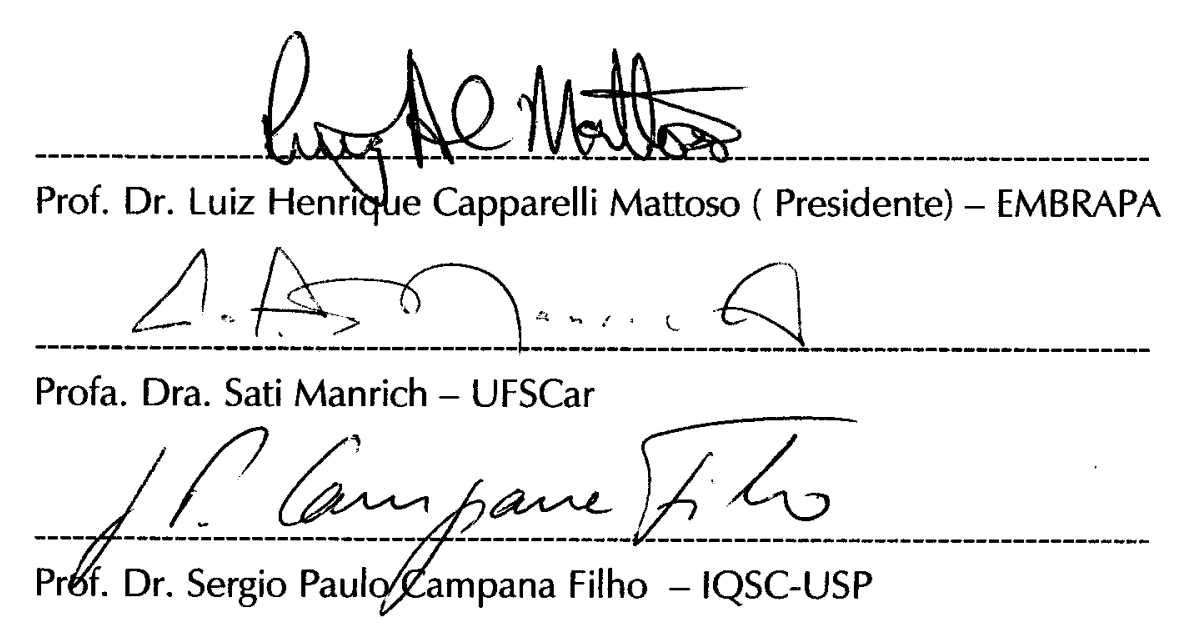


A Deus, por ter nos dado a vida e iluminar os caminhos que levam aos nossos sonhos...

"Todas as vezes que adquirires um novo interesse, ainda mais, alcançares uma nova conquista, estarás aumentando o teu poder de vida".

\section{William Lyon Phelps}

"Tudo aquilo que você pode fazer, ou sonha que pode, comece a fazer; a audácia tem em si gênio, poder e magia".

Goethe 


\section{AGRADECIMENTOS}

- Ao Dr. Luiz Henrique Caparelli Mattoso, pelo apoio, incentivo e orientações.

- À 3M do Brasil Ltda., aqui representada especialmente na pessoa de Ranjit Thakur, pela abertura e incentivo ao Programa de Pós-Graduação na Empresa.

- Ao Marco Iozzi, um amigo e constante incentivador em todas as horas.

- A Maria Alice, um sincero agradecimento e admiração por ter o dom de compartilhar o conhecimento.

- A Dr ${ }^{a}$ Regina Helena Porto Francisco, pelo incentivo e primeira acolhida na USP.

- Aos amigos Higashi e Manami, pela contribuição no design gráfico.

- A Wladerez e Cristiane, por serem muito prestativas e ajudarem muito nas horas mais difíceis.

- Ao Dr. Fábio Cezar Ferreira (UNESP - Presidente Prudente) pelas medidas de TGA e DSC.

- Ao Gallo, pelas medidas de microscopia eletrônica.

- A todos que direta ou indiretamente contribuíram para a realização deste trabalho. 
SUMÁRIO

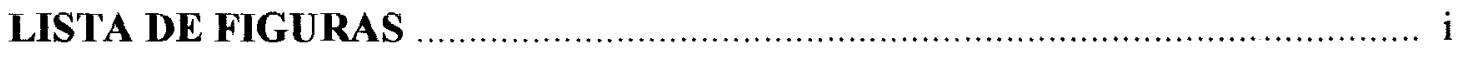

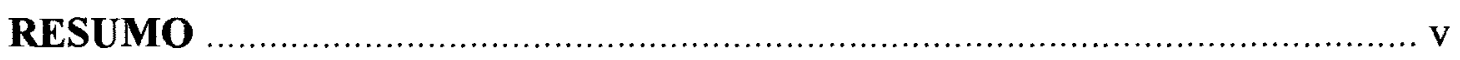

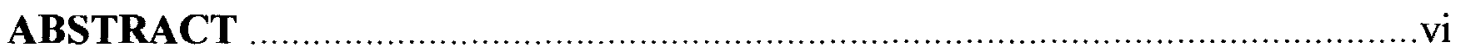

1 - INTRODUÇÃO

2 - FUNDAMENTOS TEÓRICOS E REVISÃO BIBLIOGRÁFICA

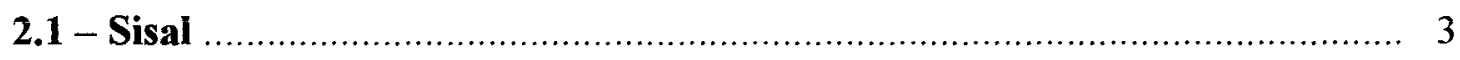

2.2 - Compósitos Poliméricos Reforçados Com Fibras Naturais …………...... 5

2.3 - Poli (cloreto de vinila) - PVC

2.3.1 - História e desenvolvimento do PVC ………...................................... 8

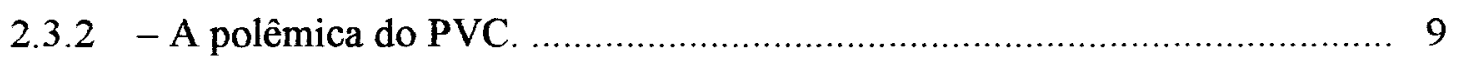

2.3.2.1 - Produção do PVC e o monômero cloreto de vinila. .................................... 10

2.3.2.2 - PVC: Um material ambientalmente correto ......................................... 11

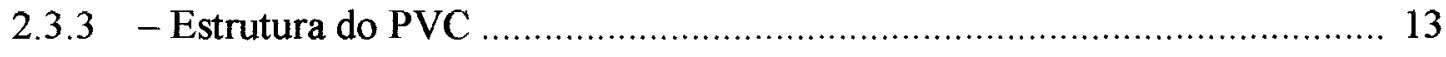

2.4 - Aspectos teóricos de plastificação

2.4.1 - Definição de plastificantes e plastificação ............................................... 16

2.4.2 - Natureza química dos plastificantes ….............................................. 17

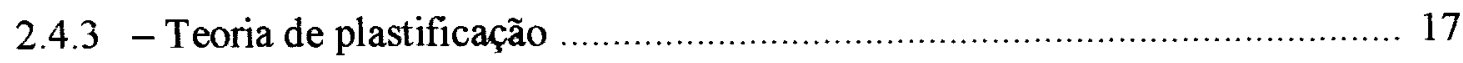


2.5.1 - A calandra.

2.5.2 - O processo de pré-calandragem.

2.5.3 - O processo de calandragem.

\section{4 - PROCEDIMENTO EXPERIMENTAL}

4.1 - Definições

\section{2 - Materiais e Métodos}

4.2.1 - Materiais

4.2.2-Métodos

4.2.2.1 - Preparação dos corpos de prova.

4.2.2.2 - Corte das Fibras de Sisal nas dimensões 3, 6 e $10 \mathrm{~mm}$

4.2.2.3 - Método de tratamento das fibras de sisal

4.2.2.4 - Avaliação da eficácia do tratamento de fibra descrito acima.

4.2.2.5 - Formulação, processamento e condições de processo das amostras

4.2.2.6 - Análise térmica (TGA e DSC)

4.2.2.7 - Ensaio mecânico de tração

\section{5 - RESULTADOS E DISCUSSÃO}

5.1 - Corte e tratamento das Fibras de Sisal

5.2 - Processabilidade dos compostos 36

5.3 - Microscopia eletrônica de varredura (MEV) 37

5.4 - Ensaios de tração

$$
\begin{gathered}
\text { SO SEPVICOODE BIBLIOTECA } \\
\text { INFOAMACÄO }
\end{gathered}
$$


5.4.1 - Variação do tamanho de fibra de sisal nos compósitos ........................ 44

5.4 .2 - Variação do teor de fibra de sisal nos compósitos ............................. 46

5.4 .3 - Variação do teor de plastificante nas matrizes poliméricas ................... 49

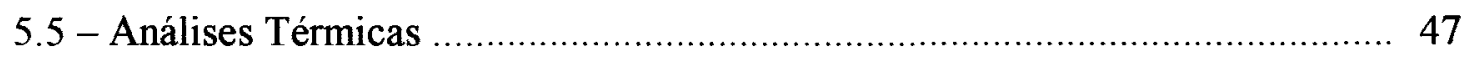

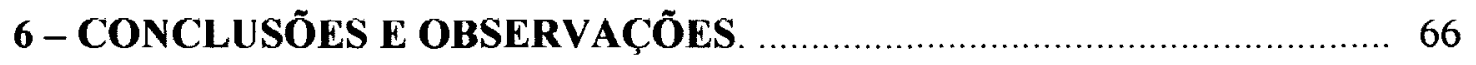

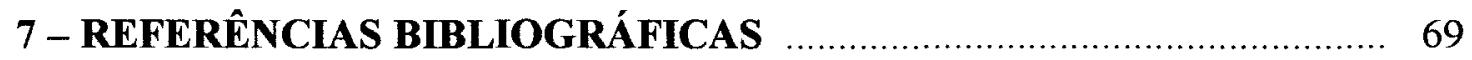




\section{LISTA DE FIGURAS}

Figura 2.1 - Exemplos de aplicação de fibras naturais em compósitos.

07

Figura 2.2 - Tempo aproximado de vida em serviço de produtos de PVC, em função do percentual de aplicação.

Figura 2.3 - Estrutura química do poli (cloreto de vinila).

Figura 2.4 - Relação entre massa molar (Mw e $\mathrm{Mn}$ ) e o valor de K para PVC

Figura 2.5 - Mecanismos de plastificação por dipolos para PVC.

Figura 2.6 - Arranjos de cilindros comumente utilizados para produção de laminados de PVC.

Figura 5.1- Distribuição percentual dos tamanhos de fibra obtidos para cada um dos três tamanhos nominais escolhidos (conjunto de valores $1=3 \mathrm{~mm}$ nominal, conjunto de valores $2=6 \mathrm{~mm}$ nominal, conjunto de valores $3=$ $10 \mathrm{~mm}$ nominal). 36

Figura 5.2 - Fotografia obtida por MEV da superficie de fibra de sisal sem tratamento. Ampliação 100x. 37

Figura 5.3 - Fotografia obtida por MEV da superficie de fibra de sisal sem tratamento. Ampliação 1000x.

Figura 5.4 - Fotografia obtida por MEV da superfície da fibra de sisal após lavagem com água quente $\left(80^{\circ} \mathrm{C}\right.$ por 1 hora $)$. Ampliação $100 \mathrm{x}$.

Figura 5.5 - Fotografia obtida por MEV da superficie da fibra de sisal após lavagem com água quente $\left(80^{\circ} \mathrm{C}\right.$ por 1 hora $)$. Ampliação $1000 \mathrm{x}$.

Figura 5.6 - Fotografia obtidas por MEV do aspecto de fratura do compósito feito a partir de matriz do tipo A (Resina PVC com plastificante líquido carregada com 15pcr de fibras de Sisal). Ampliação 500x. 
Figura 5.7 - Fotografias obtidas por MEV do aspecto de fratura do compósito feito a partir de matriz do tipo B (Resina PVC com plastificante sólido carregada com 15pcr de fibras de Sisal). Ampliação 500x 40

Figura 5.8 - Fotografia obtida por MEV do aspecto de fratura de compósito feito a partir de matriz tipo A (resina PVC com $35 \mathrm{pcr}$ de plastificante líquido e 25 pcr de sisal). Ampliação 500x

Figura 5.9 - Fotografia obtida por MEV do aspecto de fratura de compósito feito a partir de matriz tipo B (resina PVC com 35pcr de plastificante sólido Elvaloy ${ }^{\circledR}$ e $25 \mathrm{pcr}$ de sisal). Ampliação $500 \mathrm{x}$

Figura 5.10 -Fotografia obtida por MEV do aspecto de fratura de compósito feito a partir de matriz tipo A (resina PVC com 48pcr de plastificante líquido e 25pcr de sisal). Ampliação 500x 43

Figura 5.11 -Fotografia obtida por MEV do aspecto de fratura de compósito feito a partir de matriz tipo B (resina PVC com 48pcr de plastificante sólido Elvaloy ${ }^{\circledR}$ e 25 pcr de sisal). Ampliação $500 x$

Figura 5.12 -Curvas de tensão de ruptura (MPa) versus tamanho de fibra de sisal nos compósitos tipo A (PVC + 40pcr de plastificante líquido) e tipo B (PVC +40 pcr de plastificante sólido Elvaloy ${ }^{\circledR}$ ). Os compósitos apresentam 15 per de fibras de sisal

Figura 5.13 -Curvas de elongação na ruptura (\%) versus tamanho de fibra de sisal nos compósitos tipo A (PVC + 40pcr de plastificante líquido) e tipo B $\left(\mathrm{PVC}+40 \mathrm{pcr}\right.$ de plastificante sólido Elvaloy $\left.{ }^{\circledR}\right)$. Os compósitos apresentam 15 pcr de fibras de sisal 45

Figura 5.14 -Curvas de módulo elástico / 10\% de elongação (MPa) versus tamanho de fibra de sisal nos compósitos tipo A (PVC +40 pcr de plastificante liquido) e tipo B (PVC +40 pcr de plastificante sólido Elvaloy ${ }^{\circledR}$ ). Os compósitos apresentam $15 \mathrm{pcr}$ de fibras de sisal 46

Figura 5.15 -Curvas de tensão de ruptura (MPa) versus teor de fibra de sisal nos compósitos tipo A ( $\mathrm{PVC}+40 \mathrm{pcr}$ de plastificante líquido) e tipo B (PVC +40 per de plastificante sólido Elvaloy $\left.{ }^{\circledR}\right)$. Os compósitos apresentam 10 pcr, 15 pcr e 25 pcr de fibras de sisal (tamanho $6 \mathrm{~mm}$ ) comparado com a matriz pura 48

Figura 5.16 -Curvas de elongação na ruptura (\%) versus teor de fibra de sisal nos compósitos tipo A ( $\mathrm{PVC}+40 \mathrm{pcr}$ de plastificante líquido) e tipo B (PVC +40 pcr de plastificante sólido Elvaloy ${ }^{\circledR}$ ). Os compósitos apresentam 10 pcr, 15 pcr e 25 pcr de fibras de sisal (tamanho $6 \mathrm{~mm}$ ) comparado com a matriz pura 
Figura 5.17 -Curvas de módulo elástico a $10 \%$ de elongação (MPa) versus teor de compósitos tipo A (PVC $+40 \mathrm{pcr}$ de plastificante líquido) e tipo B (PVC fibra de sisal nos +40 pcr de plastificante sólido Elvaloy $\left.{ }^{\circledR}\right)$. Os compósitos apresentam 10pcr, 15pcr e 25pcr de fibras de sisal (tamanho $6 \mathrm{~mm}$ ) comparado com a matriz pura

Figura 5.18 -Curvas de tensão de ruptura $(\mathrm{MPa})$ versus teor de plastificante comparando cada uma das matrizes (tipos A e B), com e sem a adição de $25 \mathrm{pcr}$ de fibra de sisal (tamanho $6 \mathrm{~mm}$ )

Figura 5.19-Curvas de elongação na ruptura (\%) versus teor de plastificante comparando cada uma das matrizes (tipos A e B), "com" e "sem" a adição de 25 pcr de fibra de sisal (tamanho $6 \mathrm{~mm}$ )

Figura 5.20 -Curvas de elongação na ruptura (\%) versus teor de plastificante comparando cada uma das matrizes (tipos A e B), "com" e "sem" a adição de $25 \mathrm{pcr}$ de fibra de sisal (tamanho $6 \mathrm{~mm}$ ) 53

Figura 5.21 -Curvas de tensão de ruptura (MPa) versus teor de plastificante nos compósitos tipo A (PVC + plastificante líquido) e tipo B (PVC + plastificante sólido Elvaloy $\left.{ }^{\circledR}\right)$. Os compósitos apresentam $25 \mathrm{pcr}$ de fibra de sisal (tamanho $6 \mathrm{~mm}$ ) 54

Figura 5.22 -Curvas de elongação na ruptura $(\%)$ versus teor de plastificante nos compósitos tipo A (PVC + plastificante líquido) e tipo B (PVC + plastificante sólido Elvaloy $\left.{ }^{\circledR}\right)$. Os compósitos apresentam $25 \mathrm{pcr}$ de fibra de sisal (tamanho $6 \mathrm{~mm}$ ) 55

Figura 5.23 -Curvas de módulo a $10 \%$ de elongação (MPa) versus teor de plastificante nos compósitos tipo A (PVC + plastificante líquido) e tipo $\mathrm{B}\left(\mathrm{PVC}+\right.$ plastificante sólido Elvaloy $\left.{ }^{\circledR}\right)$. Compósitos têm $25 \mathrm{pcr}$ de sisal (tamanho 6mm) 55

Figura 5.24 -Retenção dos valores de tensão de ruptura das matrizes (tipos A e B) carregadas com $25 \mathrm{pcr}$ de fibra de sisal (tamanho $6 \mathrm{~mm}$ ), com relação às matrizes puras em cada teor de plastificante estudado 56

Figura 5.25 -Retenção dos valores de elongação na ruptura das matrizes (tipos A e B) carregadas com $25 \mathrm{pcr}$ de fibra de sisal (tamanho $6 \mathrm{~mm}$ ), com relação às matrizes puras em cada teor de plastificante estudado 57

Figura 5.26 -Curvas obtidas nos ensaios de tração para matriz de PVC em função do teor de plastificante líquido (sem adição de fibras de sisal) 58

Figura 5.27 -Curvas obtidas nos ensaios de tração para matriz de PVC em função do teor de plastificante líquido, carregadas com $25 \mathrm{pcr}$ de fibra de sisal (tamanho 6mm) 
Figura 5.28 -Curvas obtidas nos ensaios de tração para matriz de PVC em função do teor de plastificante sólido (Elvaloy ${ }^{\circledR}$ ), sem adição de fibras de sisal 59

Figura 5.29 -Curvas obtidas nos ensaios de tração para matriz de PVC em função do teor de plastificante sólido (Elvaloy ${ }^{\circledR}$ ), carregadas com 25 pcr de fibras de sisal (tamanho $6 \mathrm{~mm}$ ) 59

Figura 5.30 -Termograma DSC para o copolímero Elvaloy ${ }^{\circledR}$ 60

Figura 5.31 -Curvas DSC para matriz PVC plastificada com 48pcr de plastificante sólido Elvaloy ${ }^{\circledR}$ e para a mesma matriz carregada com 25 pcr de fibra de sisal. A curva para Elvaloy ${ }^{\circledR}$ puro foi colocada junto para comparação 61

Figura 5.32 -Curvas DSC comparando matrizes do tipo A (PVC $+48 \mathrm{pcr}$ de Plastificante líquido) e do tipo B (PVC + 48pcr de plastificante sólido), carregadas com 25pcr de fibras de sisal 62

Figura 5.33 -Curvas de TGA para matrizes tipos A e B com 35 e 48 pcr de plastificante. Curva para Elvaloy ${ }^{\circledR}$ foi plotada para comparação 64

Figura 5.34 -Curvas de TGA para matriz tipo A com 35 e 48pcr de plastificante líquido, com e sem a adição de fibras de sisal 65

Figura 5.35 -Curvas de TGA para matriz tipo B com 35 e 48pcr de plastificante sólido, com e sem a adição de fibras de sisal. Curva para o Elvaloy ${ }^{\circledR}$ foi plotada para comparação 65 


\section{RESUMO}

Compósitos consistindo de PVC flexível plastificado com diferentes sistemas de plastificação e reforçados com fibras de sisal, foram processados em moinho de dois rolos. Dois tipos de plastificantes foram usados, um plastificante líquido (plastificante polimérico do tipo poliéster) e um plastificante sólido permanente (copolímero etileno/ acetato de vinila/ monóxido de carbono - Elvaloy ${ }^{\circledR}$ ), formando dois tipos de matrizes poliméricas. Para cada matriz formada estudou-se a influência do teor de cada plastificante, tamanho e teor das fibras de sisal nas propriedades dos compósitos. As fibras usadas foram previamente lavadas com água a $80^{\circ} \mathrm{C}$ por uma hora. Os compósitos, com fibras aleatoriamente distribuídas, foram caracterizados através de ensaios mecânicos, microscopia eletrônica de varredura (MEV), análise termogravimétrica (TGA) e calorimetria diferencial de varredura (DSC). Para cada uma das matrizes poliméricas estudadas, o tamanho ótimo de fibra foi de $6 \mathrm{~mm}$. $\mathrm{O}$ uso do Elvaloy ${ }^{\circledR}$ como um plastificante sólido mostrou-se viável e promoveu um maior contato fibra-matriz nos compósitos, sendo um fator importante para a melhoria das propriedades mecânicas, principalmente para teores de plastificante acima de $40 \mathrm{pcr}$, comparado com o plastificante líquido. As análises térmicas (TGA e DSC) mostraram que a substituição do plastificante líquido pelo plastificante sólido, não afetou a estabilidade térmica tanto dos compósitos quanto das matrizes puras. Para ambas as matrizes poliméricas estudadas, ocorre o aumento do módulo elástico em função da adição de fibras de sisal, comparado com as mesmas matrizes puras.

$$
\begin{gathered}
\text { IFSC-USP SERVICOODE BIBLIOTECA } \\
\text { INFORMACAOO }
\end{gathered}
$$




\begin{abstract}
Composites consisting of flexible PVC, plasticized with two different types of plasticizers and reinforced with sisal fibres were processed on a two roll mixing mill. Two plasticizers were used, a liquid plasticizer (polyester polymeric) and a permanent solid plasticizer (ethylene/ vinyl acetate/ carbon monoxide copolymer Elvaloy ${ }^{\circledR}$ ), to form two kinds of polymeric matrices. For each one of these matrices, the influence of plasticizers type, plasticizers load, size and quantity of sisal fibres in the composite properties was studied. The fibres were washed using water at $80^{\circ} \mathrm{C}$ by one hour. The composites with randomly distributed fibres were characterized by mechanical analysis, scanning electron microscopy, thermogravimetric analysis (TGA) and differential scanning calorimetry (DSC). For each one of the polymeric matrices studied, the optimal size of sisal fibre was $6 \mathrm{~mm}$ in order to have a better reinforcement, under the conditions investigated. Solid plasticizer Elvaloy ${ }^{\circledR}$ was feasible for PVC compositions and promoted a better contact fibre-matrix of the composites, increasing mechanical properties for plasticizer quantity over $40 \mathrm{phr}$, compared to the liquid plasticizer. The thermical analysis (TGA and DSC) demonstrated that the replacement of the liquid plasticizer by the solid plasticizer, does not change the thermal behavior of the composites and unloaded polymeric matrices. For both matrices the elastic moduli is increase as the sisal fibres are added, when compared to unloaded matrices.
\end{abstract}




\section{1- INTRODUÇÃo}

Compósitos poliméricos contendo fibras naturais têm recebido grande atenção por parte de pesquisadores e da indústria. Fibras naturais são resistentes, abundantes, não-tóxicas, de baixo custo e provém de fontes renováveis de matéria prima, podendo servir como um excelente agente de reforço em polímeros. Dentre as fibras naturais, destaca-se o sisal como uma das mais amplamente usadas $[1,2,3]$. Alguns fatores que motivam o estudo de fibras de sisal como reforço em polímeros são os crescentes interesses da indústria em produtos ecologicamente corretos, a substituição de fibras sintéticas, a busca de novas aplicações através do entendimento da correlação entre estrutura e propriedades dos compósitos, além da redução de custo devido ao baixo preço das fibras naturais. Inúmeros polímeros têm sido usados como matrizes em compósitos reforçados com fibras naturais. Os mais comuns são os termofixos tais como poliésteres, epóxi e fenólicos. Termoplásticos como polietileno, polipropileno, PVC, etc..., também têm sido utilizados recentemente como matrizes [2,3]. Entretanto, poucos estudos têm sido relatados na literatura usando fibra de sisal como reforço em compostos de PVC. O PVC é o segundo termoplástico mais utilizado no mundo [4], podendo ser combinado com uma gama de plastificantes que produzem compostos que variam desde um sólido rígido, até um material com aspecto de borracha ou até mesmo um gel ou líquido viscoso. Devido a estas características, torna-se possível estudar diferentes sistemas de plastificação e sua interação com o reforço fibroso, de modo a buscar novas aplicações. Neste trabalho foi feito um estudo para verificar os efeitos da substituição de um plastificante líquido por um plastificante sólido, em composto de PVC processado por calandragem, bem como a utilização destas matrizes poliméricas para preparação 
de compósitos reforçados com fibras de sisal. Os plastificantes sólidos tendem a conferir aos compostos de PVC e conseqüentemente aos compósitos, uma característica de grande importância que é a permanência do plastificante (baixas taxas de migração do plastificante), mantendo as propriedades do produto ao longo de seu ciclo de vida. Os estudos foram focados na caracterização dos materiais através de ensaios mecânicos (tensão, elongação e módulo elástico) e técnicas de microscopia eletrônica de varredura (MEV), DSC e TGA, para melhor entender a correlação entre estrutura e propriedades. 


\section{2 - FUNDAMENTOS TEÓRICOS E REVISÃO BIBLIOGRÁFICA}

\section{1 - Sisal}

Há uma crescente busca por fibras de baixo custo, degradáveis, que sejam provenientes de fontes renováveis de matérias-primas, possuam boas propriedades mecânicas e térmicas e que satisfaçam os requisitos estabelecidos na norma ISO 14000. As fibras vegetais satisfazem a esses requisitos [5-8].

Fibras vegetais, como as de juta, algodão, sisal, rami e coco, têm sido utilizadas como reforço para matrizes poliméricas. Dentre estas fibras, o uso do sisal é particularmente interessante, pois, além de serem abundantes em paises tropicais como o Brasil, tem um baixo custo e crescente interesse no aumento de sua produção para diferentes aplicações $[3,5]$.

Sisal é uma das fibras naturais mais amplamente utilizadas, extraída da planta Agave sisalana, sendo uma fonte renovável de matéria prima com um ciclo de cultivo rápido [7]. Aproximadamente 4,5 milhões de toneladas de fibra de sisal são produzidas anualmente no mundo. Tanzânia e Brasil são os dois principais países produtores [8]. É importante entender a correlação entre estrutura e propriedades de compósitos formados pela associação entre fibras naturais e matrizes poliméricas. Um maior entendimento da relação entre os constituintes dos compósitos, poderá levar ao surgimento de novas aplicações tecnológicas e, conseqüentemente, ao maior aproveitamento das fibras naturais. 
As fibras naturais são constituídas quase que exclusivamente, por apenas três componentes (celulose, hemicelulose e lignina). Dentre estes componentes, destacase a celulose como a substância orgânica natural mais abundante e a lignina como uma das maiores fontes de carbonos aromáticos [9].

A composição química de fibras de sisal tem sido relatada por inúmeros grupos de pesquisadores [10-13]. Por exemplo, Wilson [10] afirma que fibra de sisal contém $78 \%$ de celulose, $8 \%$ de lignina, $10 \%$ de hemi-celulose, $2 \%$ de graxas e aproximadamente $1 \%$ de cinza por peso; mas Rowell [11] encontrou que o sisal contém $43-56 \%$ de celulose, $7-9 \%$ de lignina, $21-24 \%$ de pentosana e $0,6-1,1 \%$ de cinza. Mais recentemente, Joseph et al. [3] relata que sisal contém $85-88 \%$ de celulose. Estas amplas variações na composição química das fibras de sisal são resultado de suas diferentes fontes, idade, métodos de medida, etc... Chand e Hashmi [12] mostraram que a celulose e a lignina contidas no sisal variam de $49,62-60,95 \%$ e $3,75-4,40 \%$, respectivamente, dependendo da idade da planta.

Segundo Sarkansen [13], pode ser demonstrado que o uso de recursos naturais renováveis é suficiente para o atendimento das necessidades do mundo atual, e que já possuímos a tecnologia química necessária para produção, a partir de biomassa vegetal, de muitos produtos atualmente produzidos a partir de fósseis, tais como combustíveis e polímeros sintéticos.

O uso de fibras lignocelulósicas para o reforço de polímeros é uma técnica que já é empregada na indústria para a obtenção de materiais com melhor desempenho mecânico e térmico. Porém em muitos casos as indústrias não desenvolvem uma tecnologia adequada para o seu processamento. A substituição de fibras sintéticas por fibras naturais para reforço de polímeros, é uma possibilidade bastante atraente principalmente por ser biodegradável, de fonte renovável e de baixo 
custo, o que vem de encontro aos esforços para a preservação do meio ambiente que vem sendo buscado neste final de século $[14,15]$. As fibras naturais suportam os métodos convencionais de processamento de polímeros e possuem menor densidade que as fibras inorgânicas. Em termos nacionais o Brasil é sem dúvida um dos países que possuem uma das maiores biomassas vegetais do mundo e a maior extensão territorial cultivável, cujo potencial deve ser melhor explorado [16].

Além disso, o interesse crescente da sociedade pelo uso de materiais ecologicamente mais corretos, faz com que as fibras vegetais retomem o espaço perdido para os sintéticos em vários setores, por exemplo, podemos citar a MercedesBenz européia, que possui estofamentos com fibra de coco e borracha natural para substituir a poliuretano à base de isocianato que é altamente tóxico, principalmente quando ocorre a sua combustão.

Dentre as várias matrizes empregadas na produção de compósitos reforçados por fibras $[17,18]$, poucas são as que possuem alguma interação com as fibras naturais devido a hidrofobicidade das matrizes e a hidrofilicidade das fibras. A correlação entre estrutura e propriedades entre matrizes poliméricas e fibras naturais, continua sendo pouco entendida [19]. Um maior entendimento da relação entre os constituintes dos compósitos, também poderá levar ao surgimento de novas aplicações tecnológicas e, conseqüentemente, ao maior aproveitamento das fibras naturais $[14,20-22]$.

\section{2 - Compósitos Poliméricos Reforçados Com Fibras Naturais}

Define-se como compósito, um material conjugado formado por pelo menos duas fases ou dois componentes, sendo geralmente uma fase polimérica (matriz polimérica) e uma outra fase de reforço, normalmente na forma de fibras. Para 
formação do material compósito ou do material conjugado, é necessário haver uma interação química e/ou física entre a matriz polimérica e o reforço fibroso, proporcionando a transferência de esforços mecânicos da matriz polimérica para o reforço fibroso $[23,24]$.

No campo dos compósitos, o reforço de matrizes poliméricas foi inicialmente desenvolvido usando fibras sintéticas como, por exemplo, a fibra de vidro, fibra de carbono e fibras aramídicas, obtendo vantagens devido à alta resistência mecânica relacionada a estas fibras $[25,26]$.

$\mathrm{O}$ uso de fibras vegetais como reforço em polímeros em substituição às fibras sintéticas tem sido alvo de muitos estudos atualmente, devido a inúmeras vantagens, tais como: baixo custo, baixa densidade e alta resistência específica, além de ser uma fonte renovável de matéria prima [2, 27-29].

Fibras naturais têm sido freqüentemente usadas em matrizes poliméricas termofixas, mas seu uso em matrizes termoplásticas tem sido limitado pela incompatibilidade fibra-matriz e pela dificuldade de se obter boa dispersão da fibra na matriz polimérica [30-32]. Apesar disso, inúmeros trabalhos têm sido feitos usando matrizes termoplásticas reforçadas com fibras vegetais [33-37], levando em conta que estes polímeros podem ter diferentes níveis de afinidade com cada tipo de carga usada, devido a diferenças significativas em sua estrutura química. Como conseqüência, o efeito do reforço sobre estas matrizes pode variar amplamente. Uma avaliação de compósitos construídos a partir destas diferentes matrizes, pode levar a uma compreensão do tipo de ligação requerida na interface matriz-fibra e, também entender, o efeito das propriedades da matriz polimérica nas propriedades mecânicas do compósito [38]. 
Estudos na literatura [39,40] têm apresentado as propriedades dinâmicomecânicas, característica de envelhecimento, modificações químicas, propriedades reológicas, etc..., de materiais reforçados com fibras vegetais. Essas propriedades podem ser melhoradas em função da melhoria da qualidade e modificação química da fibra $[41,42]$ e outras características de processamento tais como, teor de fibra adicionada à matriz, orientação, incorporação de dois ou mais tipos de fibras, modificação da matriz polimérica base, dentre outros fatores [43,44].

Atualmente, a indústria automobilística e de plásticos estão recuperando o interesse por fibras vegetais devido às suas vantagens para a substituição de fibras inorgânicas/minerais, tais como a fibra de vidro e amianto. $\mathrm{O}$ sisal pode ser utilizado de maneira bastante satisfatória para reforço de peças plásticas na indústria automobilística, como mostrado na figura 2.1 a seguir.

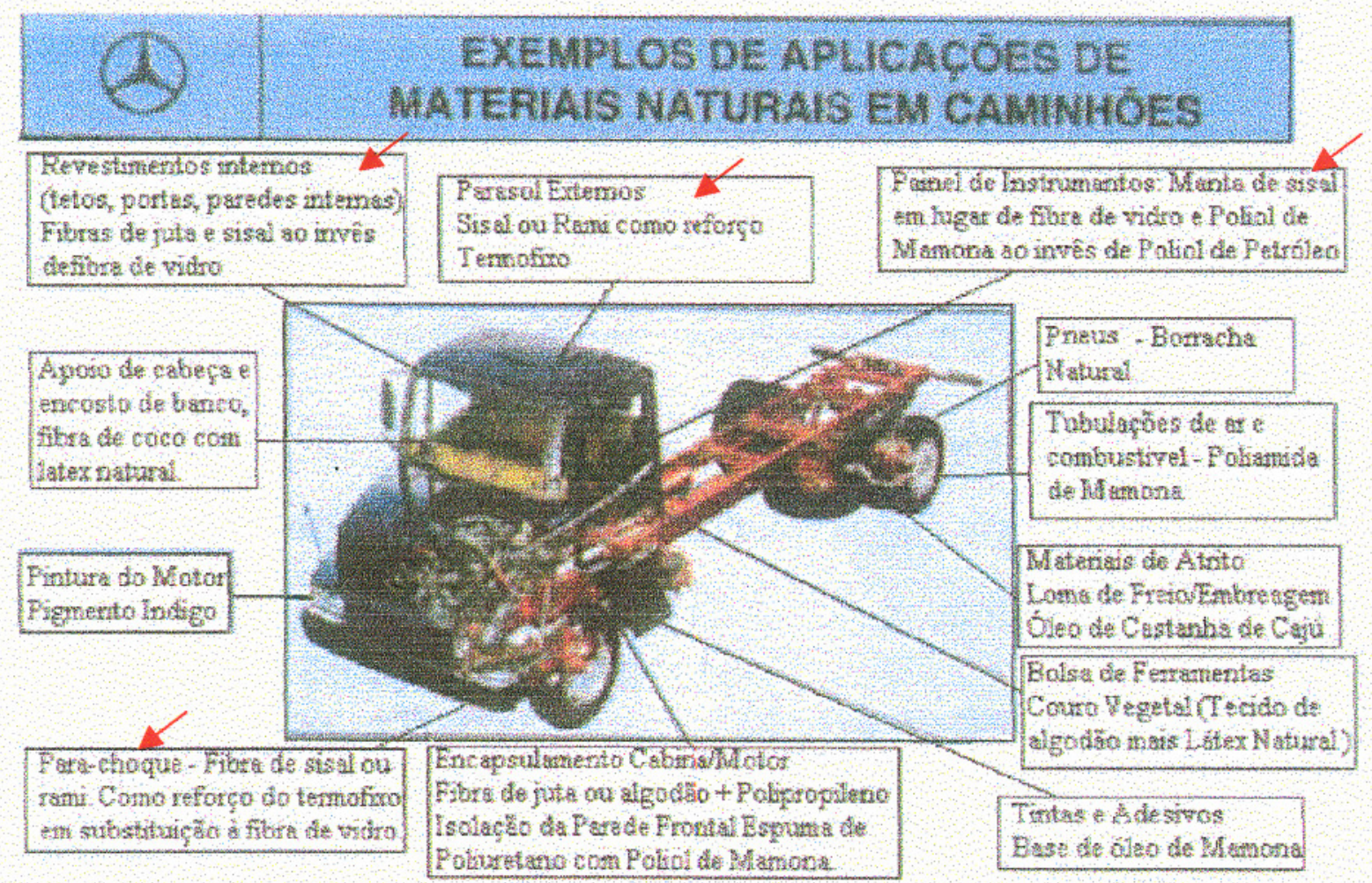

Figura 2.1- Exemplos de aplicação de fibras naturais em compósitos. As setas vermelhas na figura indicam aplicações do sisal (Fonte: Mercedes-Benz). 


\section{3- Poli (cloreto de vinila) - PVC}

\subsection{1 - História e desenvolvimento do PVC}

Apesar de Regnault ter preparado alguns monômeros de vinil e vinilideno em 1838, e observado mais tarde sua conversão em um pó branco quando exposto à luz solar em tubos selados, a "polimerização de Baumann" do cloreto de vinila em 1872 é considerada a primeira preparação documentada de PVC homopolímero. O produto obtido tinha a característica de uma massa sólida branca, resistente quimicamente a solventes e ácidos e estável sob aquecimento até a temperatura de $130^{\circ} \mathrm{C}$, mas se decompunha rapidamente com liberação de vapor ácido a temperaturas mais elevadas $[45,46]$. O Interesse prático em PVC surgiu em 1912 através de patentes geradas na Inglaterra e Alemanha para a produção de massas vinílicas com aspecto de borracha. Por volta de 1928 vieram as primeiras patentes referentes ao desenvolvimento de copolímeros cloreto de vinila/acetato de vinila pela DuPont e Union Carbide nos USA e pela IGF (atualmente Basf) na Alemanha [47]. O desenvolvimento destes copolímeros ampliou o uso do PVC que, até então como homopolímero, tinha dificuldades de processamento e aplicações limitadas devido a alta rigidez. A presença do acetato de vinila como co-monômero na fabricação dos copolímeros de PVC, muitas vezes é considerado um sistema de "plastificação interna" que flexibiliza a cadeia do polímero. A primeira produção de copolímeros na América foi feita pela Union Carbide e pela Carbon Chemicals Corporation por volta de 1928. Em 1931 a B.F. Goodrich introduziu seu próprio produto, o plástico “cloreto de vinila não-rígido" a base de copolímero vinílico. Na Alemanha, em 1931, iniciou-se a primeira produção em escala técnica de copolímeros, homopolímeros e fibras de PVC $[45,48]$. 
Efetivamente a "plastificação externa" de PVC homopolímero pela incorporação de plastificantes iniciou-se por volta de 1930 com o uso do dibutil ftalato (DBP) e outros ésteres, que podiam converter o polímero de difícil processabilidade em um material flexível e de mais baixo ponto de amolecimento, facilmente processado em seu estado de fusão e, bastante flexível ou similar a compostos de borracha em alguns aspectos, quando resfriado à temperatura ambiente. Apesar de cronologicamente a plastificação externa ter surgido após a plastificação interna pela copolimerização, atualmente ela é a principal rota para a formulação de artigos flexíveis e semi-rígidos a partir do PVC [45,48].

O PVC é o segundo termoplástico mais consumido em todo o mundo, com uma demanda mundial de resina superior a 27 milhões de toneladas no ano de 2001, sendo a capacidade mundial de produção de resina de PVC estimada em cerca de 31 milhões de toneladas ao ano. Dessa demanda total, $22 \%$ foram consumidos nos Estados Unidos, $22 \%$ nos países da Europa Ocidental e $7 \%$ no Japão. O Brasil foi responsável pelo consumo de cerca de 2,5\% da demanda mundial de resinas de PVC. Estes números mostram o potencial de crescimento da demanda de resinas de PVC no Brasil, uma vez que o consume per capita, na faixa de $4,0 \mathrm{~kg} / \mathrm{hab} / \mathrm{ano}$, ainda é baixo se comparado com o de outros países [4].

\subsection{2 - A polêmica do PVC}

Possíveis riscos à saúde e ao meio ambiente, envolvem a produção, processamento e uso de muitos materiais poliméricos, e o PVC não é uma exceção. As principais áreas de risco podem estar relacionadas, de modo geral, com efeitos danosos provenientes do contato direto com a resina de PVC ou com produtos fabricados a partir dele, com componentes que o constituem, ou ainda efeitos 
danosos provenientes da decomposição, durante qualquer etapa do ciclo de vida destes produtos [48].

\subsubsection{1 - Produção do PVC e o monômero cloreto de vinila}

A produção do PVC é feita a partir da polimerização do monômero cloreto de vinila (MVC), que é reconhecidamente um agente cancerígeno. As plantas de produção do PVC atendem a normas rígidas de saúde ocupacional, mantendo os níveis de MVC constantemente monitorados e, principalmente, abaixo de limites definidos por legislação específica, de modo a garantir baixo risco de exposição dos trabalhadores destes locais.

A conversão na reação de polimerização normalmente varia entre 75 e 95\%. O monômero cloreto de vinila não reagido é recuperado em uma primeira etapa após a polimerização e, posteriormente, eliminado de maneira forçada por meio de métodos apropriados como, por exemplo, aquecimento com vapor da lama de PVC.

O teor de MVC residual na resina de PVC é determinado por meio de técnicas de cromatografia, tal como descrito na norma ASTM D-3749. Esse método prescreve a técnica de headspace para remoção do MVC da resina de PVC antes da análise cromatográfica. Resinas com teores de MVC residual na de partes por bilhão (ppb) são avaliadas por meio de método descrito na norma ASTM D-4443, mais sensível que o anterior.

O teor de MVC residual é função direta das condições de polimerização, tratamento posterior da resina e, principalmente, porosidade. Resinas mais porosas permitem a remoção do MVC residual com maior facilidade, enquanto que resinas de baixa porosidade apresentam maior dificuldade de eliminação. Os resultados de ensaios são ainda sensíveis ao intervalo de tempo entre a produção da resina e a 
realização da análise, uma vez que mesmo à temperatura ambiente o MVC residual possui taxa característica de dessorção da resina.

As resinas comerciais apresentam teores de MVC residual inferiores a $1 \mathrm{ppm}$, em concordância com as exigências apontadas pelos órgãos responsáveis de diversos países do mundo, tal como o FDA (Food and Drug Administration), o órgão regulamentador de alimentos e fármacos nos Estados Unidos, e o Instituto Adolfo Lutz, no Brasil [4].

\subsubsection{2 - PVC: Um material ambientalmente correto}

Devido à sua estrutura molecular, o PVC é obtido a partir de $57 \%$ de insumos provenientes do sal marinho ou da terra (salgema), e somente $43 \%$ de insumos provenientes de fontes não renováveis como o petróleo e o gás natural. Estima-se que somente $0,25 \%$ do suprimento mundial de gás e petróleo são consumidos na produção do PVC. Vale ressaltar que existe tecnologia disponível para a substituição dos derivados de petróleo e gás pelos de álcool vegetal (cana de açúcar e outros).

$\mathrm{O}$ cloro presente na estrutura molecular do PVC é proveniente do sal marinho ou salgema ou cloreto de sódio, uma fonte praticamente inesgotável de matériaprima. Além do uso na produção do PVC, correspondente a cerca de $34 \%$ de sua demanda mundial, o cloro é utilizado em aplicações nas indústrias de cosméticos, purificação de água, papel e celulose, desinfetantes para piscinas, agricultura e indústria farmacêutica, dentre outras. Devido a seu processo de obtenção, baseado na eletrólise de uma mistura de sal e água, o cloro deve ser utilizado em balanço com a soda cáustica. $O$ processo ainda fornece hidrogênio, normalmente utilizado como combustível nas próprias plantas para geração de energia. 
A presença do átomo de cloro em sua estrutura molecular torna o PVC um polímero naturalmente resistente à propagação de chamas, contribuindo para aplicações nas quais o retardamento à chama é item desejado, tais como em fios e cabos elétricos, eletrodos e forros/revestimentos residenciais. Além disso, o grande teor de cloro presente na estrutura molecular do PVC torna sua molécula polar, o que aumenta sua afinidade e permite sua mistura com uma gama de aditivos muito maior que a de qualquer outro termoplástico, possibilitando a preparação de formulações com propriedades e características perfeitamente adequadas a cada aplicação.

$\mathrm{O}$ átomo de cloro atua ainda como um marcador nos produtos de PVC, permitindo a separação automatizada dos resíduos de produtos produzidos com esse material de outros plásticos em meio ao lixo sólido urbano, facilitando, assim, sua separação para reciclagem.

O PVC é reciclável. No Brasil a reciclagem do PVC é realizada há décadas e existe toda uma estrutura industrial organizada para esse fim. Além da tradicional reciclagem mecânica, existem disponíveis outras tecnologias como a reciclagem energética e química.

O PVC é caracterizado como um material de aplicações de longo ciclo de vida, ou seja, aplicações nas quais o tempo de vida útil do produto antes de seu descarte para o meio ambiente é bastante longo, por exemplo, mais de 20 anos. A figura 2.2 apresenta o tempo de vida útil aproximado dos principais produtos feitos com PVC e seu percentual de utilização. 


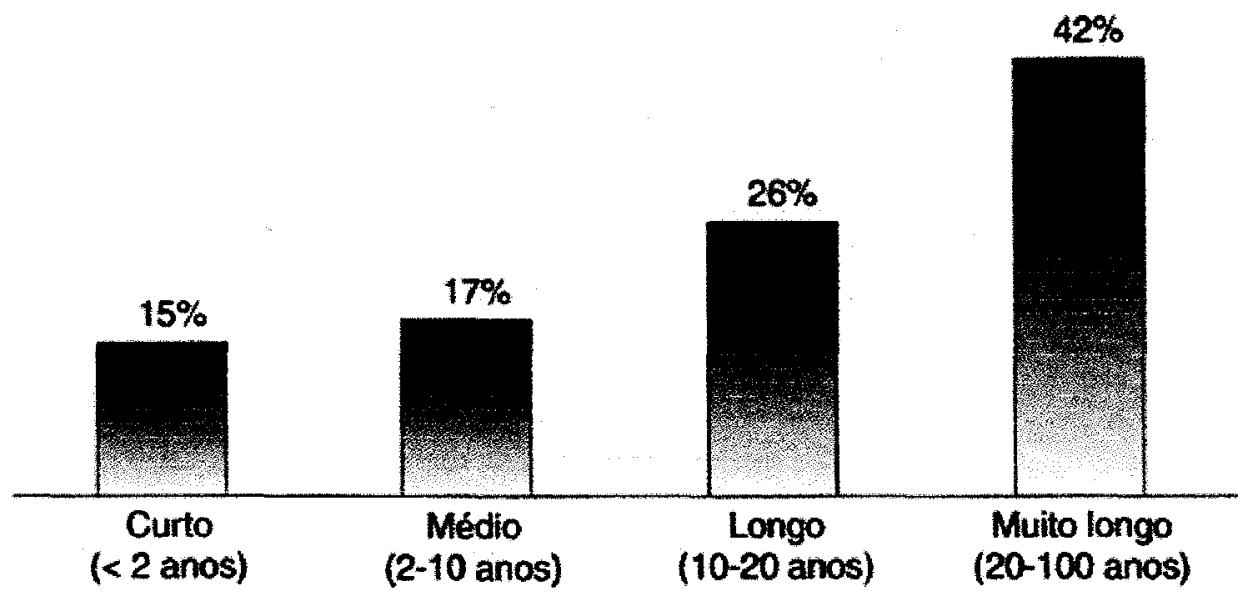

Figura 2.2- Tempo aproximado de vida em serviço de produtos de PVC, em função do percentual de aplicação [4].

Curto: Embalagens, artigos médico-hospitalares, materiais de escritório, frascos; Médio: Brinquedos, estofados, calçados;

Longo: Laminados e chapas, fios e cabos, pisos móveis, aplicações automobilísticas; Muito longo: Laminados e chapas, tubos e conexöes, mangueiras, perfis, cabos.

Devido a suas características, fica evidente que o PVC é matéria-prima do desenvolvimento sustentável, tanto por sua versatilidade quanto pelos segmentos de mercado nos quais participa, notadamente aqueles ligados diretamente à construção civil, o que torna relevante científica e socialmente qualquer projeto de pesquisa cujo tema seja esse material tão especial [4].

\subsection{3 - Estrutura do PVC}

Poli (cloreto de vinila), PVC, é um polímero termoplástico convencional sintetizado a partir do monômero cloreto de vinila cuja unidade básica de repetição na cadeia polimérica é mostrada na figura 2.3: 


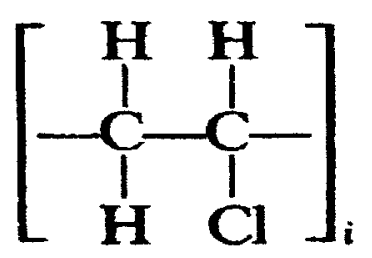

Figura 2.3 - Estrutura do poli (cloreto de vinila) [48].

Onde $i$ é o grau de polimerização, isto é, o número de unidades que se repetem na cadeia polimérica.

Em polímeros comerciais de PVC os valores médios de $i$ estão entre 500 e 1.500; isto corresponde a uma massa molar teórica em torno de 31.000 a 94.000 . Dependendo do método de determinação, este valor poderá na prática estar relacionado com uma massa molar numérica média (Mn), uma massa molar ponderal média (Mw) ou uma massa molar média viscosimétrica (Mv) [48]. Para um mesmo lote do polímero, estes valores estão na seguinte sequência: $\mathbf{M w}>\mathbf{M v}>\mathbf{M n}$, sendo $\mathbf{M v}$ normalmente mais próximo a $\mathrm{Mw}$. Num caso ideal onde todas as cadeias do polimero têm o mesmo comprimento, teremos $\mathbf{M n}=\mathbf{M w}$.

Medidas de viscosidade do polímero em solução podem ser usadas para calcular Mv ou, mais comumente para PVC, outros parâmetros tais como o valor de $K$ (Fikentscher value) que está relacionado com massa molar média do polimero.

Muitos polímeros comerciais de PVC têm um valor de K de 50-80, equivalente a aproximadamente $50.000-500.000 \mathrm{Mw}$ e $30.000-90.000 \mathrm{Mn}$. A relação entre estes parâmetros é mostrada na figura 2.4 a seguir: 


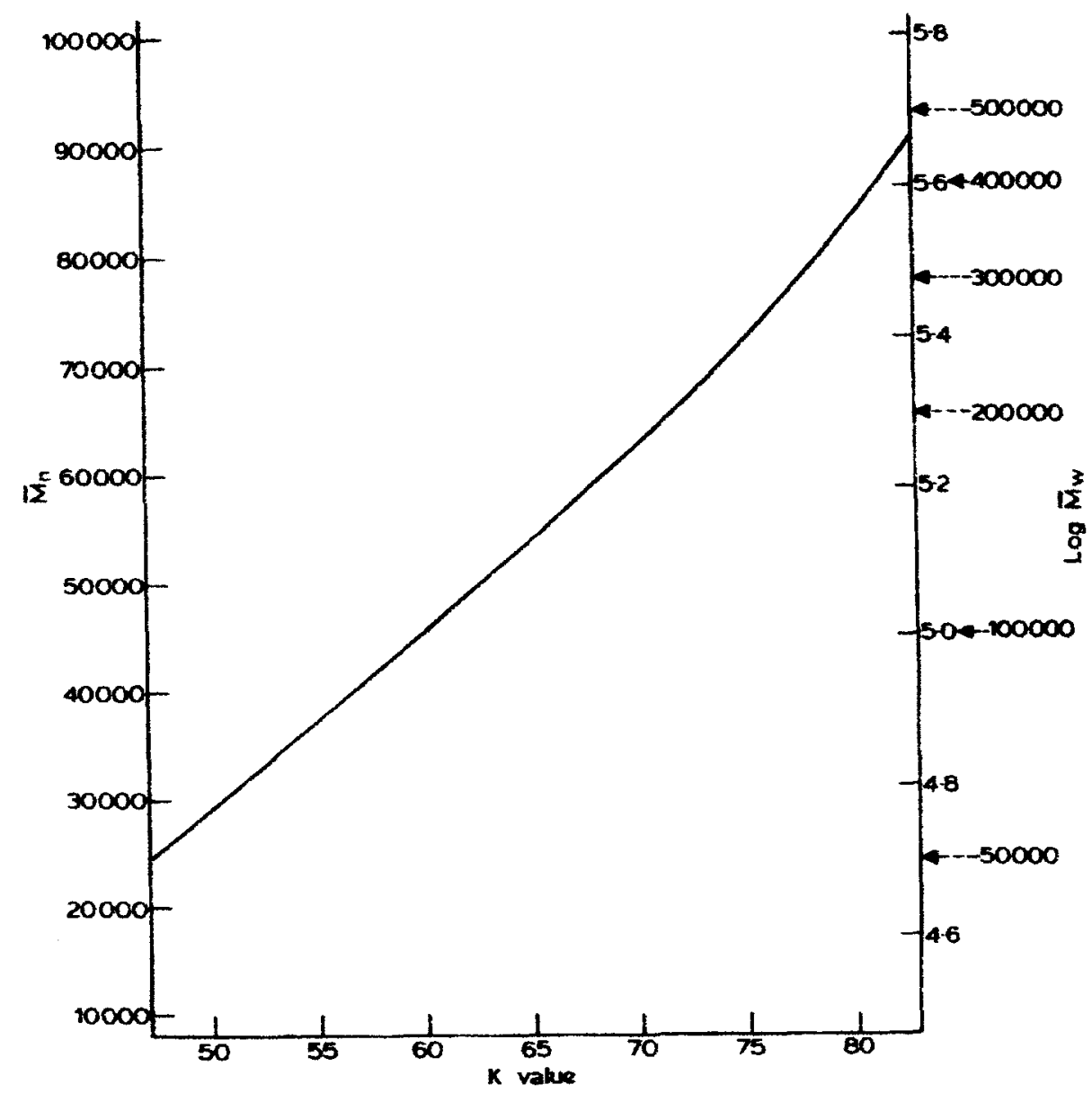

Figura 2.4 - Relação entre massa molar (Mw e Mn) e o valor de K para PVC [48].

Em geral, quanto maior a massa molar dos polimeros (e conseqüentemente o valor de K), melhores serão as propriedades mecânicas da composição, porém, mais dificil será seu processamento devido a uma maior dificuldade de fusão e mais altas viscosidades de processo. A escolha da massa molar adequada (valor $\mathrm{K}$ ) para um polimero comercial para ser usada em uma determinada formulação, é normalmente um compromisso entre as condições de processamento e as propriedades finais do composto [48]. 


\section{4 - Aspectos teóricos de plastificação}

\subsection{1 - Definição de plastificantes e plastificação}

Um plastificante pode ser definido como uma substância que quando incorporada a um material (usualmente um plástico ou elastômero), promove um aumento de sua flexibilidade, processabilidade ou distensibilidade. Um plastificante pode reduzir a viscosidade de um material no estado fundido, abaixar a temperatura de transição vítrea ou reduzir o módulo elástico $[48,49]$.

Para PVC, plastificantes convertem uma resina rígida e de difícil processamento em um composto facilmente processável que pode exibir uma ampla faixa de propriedades, dependendo do tipo e concentração do plastificante utilizado.

As propriedades requeridas para os plastificantes, normalmente incluem compatibilidade com a resina, baixa volatilidade, não inflamabilidade, boa estabilidade ao calor e a luz, bom desempenho em baixas temperaturas e baixa toxidez. Alguns destes requisitos podem ser conflitantes e geralmente um plastificante usado sozinho normalmente não atende todas as necessidades. Por esta razão, é comum o uso de mistura de diferentes plastificantes.

Plastificantes podem ser divididos em dois grupos: plastificantes primários ou secundários. Plastificantes primários são altamente compatíveis com o PVC em teores tão altos como 150pcr. Plastificantes secundários são menos compatíveis e são geralmente usados em misturas com plastificantes primários para alcançar determinado balanço de propriedades. 


\subsection{2 - Natureza química dos plastificantes}

Plastificantes usados em PVC são principalmente ésteres orgânicos com alto ponto de ebulição. Aproximadamente dois terços dos plastificantes em geral são diésteres do anidrido ftálico cuja cadeia alquílica do álcool usado em sua obtenção contém de 4 a 10 átomos de carbono na cadeia. Outras classes de plastificantes, considerados especiais, são triaril fosfatos, alquil ésteres, alquil trimetilatos, poliésteres de alto massa molar e epóxi [48].

As expressões "plastificante monomérico" e "plastificante polimérico" são comuns e amplamente usadas. A palavra "monomérico", é usada apenas em oposição ao termo "polimérico" e significa plastificante de baixa massa molar, geralmente entre 300 e 500 . No caso dos plastificantes poliméricos, o processo de polimerização pode gerar plastificantes com massa molar de 8.000 . A maior parte dos plastificantes poliméricos são poliésteres saturados resultantes da reação entre um glicol (álcool polihídrico) e um ácido dicarboxílico [48].

\subsection{3 - Teoria de plastificação}

Duas principais teorias têm sido propostas para explicar o efeito da plastificação. Na teoria da lubrificação, defendida inicialmente por Kirkpatrick $[48,49]$, considera-se que o plastificante age como um lubrificante que facilita $o$ deslizamento entre as cadeias do polímero, facilitando a deformação por redução da fricção intermolecular.

Uma teoria alternativa foi desenvolvida através do trabalho de Doolittle [49] e tornou-se conhecida como teoria de Gel. Esta teoria sugere que a resistência à deformação de polímeros amorfos é devida a formação de uma estrutura 
tridimensional similar a favos de mel, com ligações cruzadas (não covalentes), formadas a partir dos centros ativos ao longo das cadeias poliméricas. Estes centros ativos são desfeitos e se refazem continuamente. Em um sistema plastificado, enquanto as moléculas do polímero estão continuamente num processo de quebra e reconstrução dos contatos umas com as outras, as moléculas do plastificante estão também se ligando aos centros ativos. O efeito combinado é tal que, sob determinadas condições, uma determinada proporção de centros ativos serão solvatados pelas moléculas de plastificante e como conseqüência, serão eliminados potenciais pontos ativos na cadeia polimérica reduzindo a capacidade de formação de ligações cruzadas (não covalentes).

Tem sido sugerido que no caso do PVC, estes centros ativos são os dipolos na cadeia polimérica. O mecanismo de atração por dipolos foi estudado por Leuchs [48, 50] e sugere dois tipos de atração por dipolos exemplificado na Figura 2.5 .
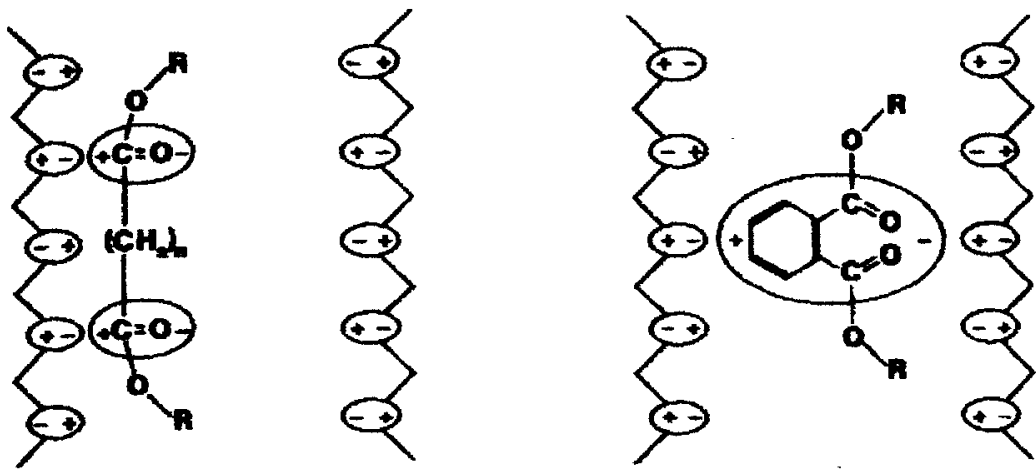

Figura 2.5 - Mecanismos de plastificação por dipolos para PVC [48].

O primeiro tipo de atração por dipolos pode ser exemplificado por plastificantes constituidos por compostos aromáticos polarizáveis e o segundo, por plastificantes polares do tipo ésteres alifáticos. 
Uma explicação mais plausível proposta para os centros ativos no PVC é que as ligações cruzadas (não covalentes) são áreas onde há uma estrutura ordenada das cadeias poliméricas ou cristalitos. Esta suposição foi investigada por Walter [48,51], que estudou a cristalização do PVC na presença de plastificante, incluindo estudos comparando a rede de cristalitos do PVC com a borracha vulcanizada.

De um modo geral, a interação entre plastificante e PVC é bastante complexa e depende da correlação de uma série de fatores em diferentes níveis, podendo incluir a energia e entropia resultantes da redistribuição das cadeias poliméricas, ou ainda do nível de interação dos dipolos com os cristalitos.

Alguns requisitos são de extrema importância para plastificantes usados em PVC:

a)- Compatibilidade e facilidade de incorporação.

b)- Facilidade para se alcançar as propriedades desejadas (usualmente flexibilidade) para um composto plastificado.

c)- Permanência (englobando volatilização, extração e migração).

Normalmente, alguns plastificantes são úteis para se alcançar determinadas propriedades, porém, podem ao mesmo tempo deteriorar outras. Por exemplo, uma alta taxa de difusão aumentará a eficiência e taxa de gelificação, porém, a permanência deste plastificante provavelmente será pobre. Um bom plastificante é aquele que consegue simultaneamente, reunir todos os três requisitos a um nível adequado para cada tipo de aplicação. Na prática, a escolha é geralmente um compromisso que envolve a técnica de processamento, a aplicação final e o custo.

Dentre os requisitos citados, a permanência é sem dúvida um fator extremamente importante. É óbvio que, após a formulação de um composto plastificado, suas propriedades permaneçam inalteradas ao longo do tempo. A perda 
do plastificante pode causar mudanças não somente nas propriedades do composto formulado, mas, também causar efeitos indesejáveis no meio externo ou em materiais que estão em contato. Por exemplo, pisos fabricados com PVC plastificado, colados com adesivo a base de betume, ao longo do tempo podem perder sua aderência por efeitos da migração de plastificantes presentes no composto. Portanto, permanência é uma característica fundamental para um bom plastificante. Existem três modos mais comuns de perda de um plastificante a partir de um composto de PVC plastificado:

a)- Volatilização (o plastificante é perdido quando em contato com o ar).

b)- Extração (o plastificante é perdido quando em contato com um líquido).

c)- Migração (o plastificante é perdido por transferência entre duas superficies em contato) [48].

Na prática, inúmeros estudos que envolvem o desenvolvimento de diferentes sistemas de plastificação têm sido feitos, com o objetivo de melhorar a permanência. Entre eles, o desenvolvimento de plastificantes de alta massa molar, polímeros e copolímeros polares compatíveis com a resina de PVC. Alguns exemplos são o uso de borracha nitrílica como plastificante na extrusão de mangueiras de PVC, o uso de elastômeros de poliuretano [52], poliolefinas cloradas e copolímeros de etileno [53]. Quimicamente, estes polímeros (ou copolímeros), por terem uma estrutura polar, tem uma afinidade natural (miscibilidade) com outros polímeros polares como o PVC. Dependendo da polaridade e da estrutura das cadeias poliméricas, uma vez misturados, estes sistemas tendem a permanecer juntos naturalmente sem separação de fases. Normalmente estas resinas poliméricas chamadas comumente de plastificantes sólidos, devido à sua elevada massa molar, não podem migrar, mantendo as propriedades originais do composto ao longo do tempo [53]. 
Neste trabalho foi feito um estudo para a substituição do sistema de plastificação líquido para PVC por um sistema sólido, um copolímero Etileno / Acetato de vinila / Monóxido de carbono. Este copolímero, devido ao seu caráter polar, tem afinidade química com o PVC, podendo atuar como um sistema plastificante.

O processo utilizado para confecção das amostras para estudo foi o de calandragem, processo bastante utilizado, tanto em nível científico como industrial, na fabricação de filmes plásticos a partir do PVC [45].

Neste projeto foram preparados compósitos pelo processo de calandragem. Os compósitos foram formados pela adição de fibras de sisal em duas diferentes matrizes poliméricas tendo o poli (cloreto de vinila)-PVC como principal polímero constituinte destes compósitos. A primeira, constituída de um composto de PVC plastificado (plastificante líquido) e a outra matriz, constituída por uma blenda de PVC/ copolímero Etileno/Acetato de vinila/Monóxido de carbono. Nesta última, o copolímero foi utilizado para atuar como um plastificante sólido ou permanente. As matrizes em estudo são consideradas termoplásticas, ou seja, nenhum tipo de ligação cruzada ocorre entre as cadeias poliméricas que formam as matrizes, podendo ser amolecidas por elevação da temperatura e processadas nesta fase, voltando a tomar a forma rígida por diminuição da temperatura. Os compósitos em estudo, transformados em filmes pelo processo de calandragem, tiveram suas propriedades estudadas através de ensaios mecânicos, microscopia eletrônica de varredura e análises térmicas. 


\section{5- Calandragem}

$\mathrm{O}$ processo de calandragem consiste na alimentação do $\mathrm{PVC}$, previamente fundido, entre dois cilindros de alimentação que o comprimem para a formação de um filme ou chapa de espessura desejada, obtida por meio de passagem posterior do composto pela abertura de uma sequeência de cilindros. A espessura do filme é controlada pela abertura dos rolos finais da calandra e seu acabamento superficial é determinado pelo acabamento da superficie dos dois últimos cilindros de passagem (cada cilindro dando acabamento em uma das faces). Normalmente, cilindros posicionados em sequêencia à calandragem, podem promover diferentes tipos de acabamento, desde uma superfície fosca até extremamente brilhante, ou ainda gofrado em uma variedade de texturas. O filme após deixar a calandra, pode simplesmente ser resfriado, embobinado ou cortado no tamanho desejado, ou ainda laminado enquanto quente sobre uma base contínua de papel ou tecido.

As principais vantagens do processo de calandragem para obtenção de laminados com relação à extrusão através de matriz plana, são a maior produtividade, excelente controle de espessura (permitindo inclusive sua automação) e possibilidade de produção contínua por períodos de tempo mais prolongados, sem a necessidade de parada de linha para limpeza. Essas vantagens são as maiores responsáveis pelo fato de a maioria dos laminados de PVC serem produzidos por calandragem, apesar da maior necessidade de investimento de capital em equipamentos e menor flexibilidade de operação para pequenas produções $[4,48]$. 


\subsection{1 - A calandra}

A calandra compreende um arranjo de cilindros, também conhecidos por rolos, montados sobre blocos suportados por estruturas laterais equipadas com guias para os rolos, engrenagem de ajuste fino da abertura e sistema de aquecimento.

As calandras utilizadas para produção de laminados de PVC são geralmente dotadas de quatro rolos. Embora não haja nenhuma razão para limitar o número de rolos a quatro além de custo, ocupação de espaço e complexidade estrutural, calandras de cinco rolos não são comuns, sendo utilizadas apenas para propósitos especiais, como na produção de alguns tipos de laminados rígidos finos em que a abertura externa permite melhoria significativa do acabamento superficial. A figura 2.6 mostra esquematicamente os quatro tipos principais de arranjos de cilindros utilizados na produção de laminados de PVC.
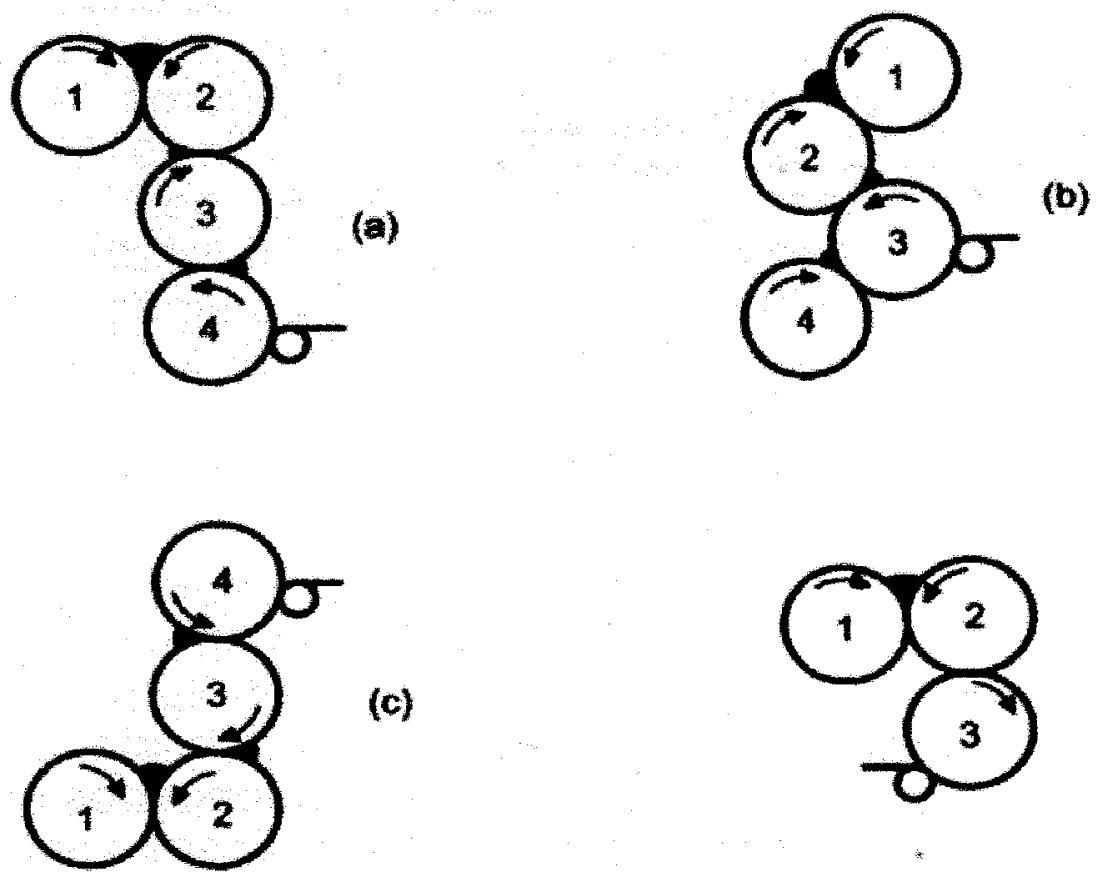

(c)

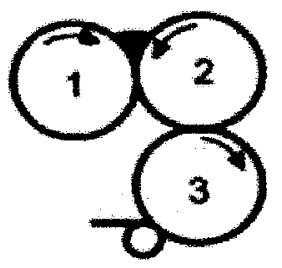

(d)

Figura 2.6- Arranjos de cilindros comumente utilizados para produção de laminados de PVC: (a) "L" invertido; (b) " $Z$ " inclinado; (c) " $L$ "; (d) Modelo de impressão de três rolos [4]. 
As vantagens das configurações em " $L$ " são a boa relação custo/benefício, boa visibilidade e acessabilidade de todos os rolos da estrutura, boa rigidez estrutural imposta pela superposição vertical de três dos quatro rolos, boa amplitude da volta total do material em torno dos rolos (acima de $540^{\circ}$ dependendo do posicionamento do rolo de impressão) e possibilidade de corrigir a espessura nas duas margens do laminado.

Outro fator importante no desenho da calandra é o sistema de compensação da espessura na região central de cada rolo. Por efeito da flexão causada pela pressão do composto fundido, os rolos tendem a abrir levemente em sua porção intermediária, levando ao aumento da espessura do laminado nessa região em comparação com as extremidades. Para compensar essa flexão foram concebidos três sistemas, sendo: (a) rolos com maior diâmetro no centro; (b) leve cruzamento dos rolos, o que aumenta a abertura nas extremidades; e (c) aplicação de momento fletor contrário nas extremidades dos rolos $[4,48]$.

\subsection{2 - O processo de pré-calandragem}

A resina de PVC é misturada aos demais aditivos utilizados na formulação do composto por meio de misturadores intensivos. Como em todo processo de moldagem do PVC, a pré-mistura é de extrema importância para garantir um composto homogêneo e livre de imperfeições, como pontos infundidos e aglomerados de aditivos, os quais podem causar defeitos no laminado.

A plastificação do composto pode ser conseguida por meio de uma série de equipamentos: misturadores contínuos, extrusoras planetárias ou ainda misturadores internos do tipo Banbury. As vantagens dos misturadores internos são sua capacidade 
de transferência de calor e os reduzidos custos de manutenção de rotina. Apresentam ainda alta capacidade de cisalhamento do composto, permitindo eficiente gelificação, plastificação e homogeneização da massa plastificada.

No caso de misturadores internos há ainda a necessidade da utilização de cilindros malaxadores imediatamente em sua saída, os quais recebem a carga de composto fundido, dosando-o na forma de um tarugo ou tubete de seção cilíndrica ou chata em uma extrusora curta dotada de filtros do tipo tela. Esses filtros se destinam à retenção de contaminantes que eventualmente possam existir no meio da massa fundida, os quais poderiam danificar o acabamento dos cilindros da calandra. Da extrusora sai um tubete pronto para alimentar a calandra $[4,48]$.

$\mathrm{O}$ elemento final de uma linha típica de pré-calandragem é a correia transportadora, responsável por levar o tubete de material fundido até os rolos iniciais da calandra. Essa correia é normalmente montada sobre um pivô giratório, permitindo a alimentação uniforme dos rolos da calandra ao longo de todo o seu comprimento. Para manutenção da temperatura da massa plastificada, o tubete deve apresentar a menor área específica possível, ou seja, deve ser preferencialmente de secção cilíndrica, ou ainda ser aquecido por algum meio (por exemplo, radiação do tipo infravermelho) se transportado por distâncias maiores que dois metros. A correia transportadora pode ainda incorporar detectores de metais como elementos adicionais de proteção da integridade dos cilindros da calandra $[4,48]$.

\subsection{3 - O processo de calandragem}

Uma vez que o composto de PVC é alimentado na calandra já totalmente gelificado e fundido, a única função desta é conformá-lo na forma de um laminado de espessura uniforme e definida. A conformação é obtida gradualmente pela 
passagem consecutiva por diversas aberturas entre rolos. Duas condições de operação atuam na passagem do material pelos rolos, determinando assim seu caminho: a aderência do composto à superfície dos rolos e o diferencial de velocidades entre rolos na abertura.

A menos que lubrificado em excesso, o composto de PVC fundido adere naturalmente à superficie aquecida dos rolos, sendo que a aderência diminui com a melhoria do acabamento superficial do rolo e aumenta com a elevação da temperatura. Além do mais, o composto fundido sofre aderência sempre ao rolo de maior velocidade, quando passado pela abertura de dois rolos de mesma qualidade de acabamento. Portanto, para que o processo flua normalmente, expulsando o composto laminado da calandra, tanto a temperatura quanto a velocidade dos rolos devem aumentar ao longo da linha. Vale destacar que o efeito do acabamento superficial dos rolos é mais significativo que os efeitos da temperatura e da diferença de velocidade.

As diferenças de temperatura para um par de aberturas consecutivas geralmente são bastante pequenas, sendo da ordem de $10^{\circ} \mathrm{C}$ no máximo. A faixa de temperatura de trabalho da linha varia geralmente entre 150 e $190^{\circ} \mathrm{C}$.

Apesar de o processo de calandragem apresentar baixo cisalhamento, deve-se atentar para a formulação do composto, especialmente no tocante à estabilização térmica e lubrificação, uma vez que a energia mecânica transferida no processo pode provocar aumento substancial de temperatura da massa. Esse aumento de temperatura deve ser compensado no ajuste das temperaturas dos rolos, de modo a evitar degradação térmica do material $[4,48]$. 


\section{3 - OBJETIVOS}

Este trabalho tem os seguintes objetivos:

a)- Estudar o efeito da substituição de um plastificante líquido convencional (poliéster polimérico) por um plastificante sólido permanente (copolímero etileno/acetato de vinila/monóxido de carbono - Elvaloy ${ }^{\circledR}$ ) em compostos de PVC processados por calandragem. Avaliar o efeito do teor de plastificante no intervalo de 35 a 48 pcr nas propriedades do produto.

b)- Para cada uma das matrizes poliméricas preparadas no item anterior (PVC + plastificante líquido e PVC + plastificante sólido), avaliar o efeito da incorporação de fibras de sisal para confecção de compósitos como segue:

- Otimizar o tamanho de fibra para cada matriz através de ensaios mecânicos. Para o tamanho ótimo de fibra, estudar o efeito da concentração das fibras nas matrizes.

- Estudar o efeito da variação do teor de plastificantes para uma concentração fixa de fibras.

O estudo envolve a preparação e caracterização destes compostos através de ensaios mecânicos (tensão, elongação e módulo elástico). Técnicas como microscopia eletrônica de varredura (MEV), DSC e TGA são importantes para auxiliar no entendimento da correlação entre estrutura e propriedade dos materiais. 


\section{4- PROCEDIMENTO EXPERIMENTAL}

\section{1 - Definições}

Primeiramente, consideremos a definição dos tipos de matrizes poliméricas em estudo. Esta definição está relacionada com o tipo de plastificante usado (líquido ou sólido) na constituição destas matrizes:

- Matriz polimérica Tipo A: Resina de PVC com plastificante líquido.

- Matriz polimérica Tipo B: Resina de PVC com plastificante sólido Elvaloy ${ }^{\circledR}$ (Blenda PVC / Elvaloy ${ }^{\circledR}$ ).

- $\quad$ ppcr : significa " $x$ " partes de qualquer componente da formulação (p.ex. fibra, plastificante) relativa a cada 100 partes de resina de PVC.

\section{2- Materiais e métodos}

\subsection{1 - Materiais}

As fibras estudadas neste trabalho foram fornecidas pela EMBRAPA (Empresa Brasileira de Pesquisa Agropecuária). O copolímero foi fornecido pela empresa DuPont e todas as outras matérias-primas necessárias para confecção dos compósitos, foram fornecidas pela empresa $3 \mathrm{M}$ do Brasil. A seguir, são apresentadas algumas das principais características das matérias-primas básicas utilizadas na composição das matrizes poliméricas: 
- Resina PVC: resina de suspensão, valor K=66.

- Copolímero: resina Etileno / Acetato de vinila / monóxido de carbono (Elvaloy ${ }^{\circledR}$ ) Índice de fluidez $=35 \mathrm{~g} / 10$ minutos.

Densidade $=1 \mathrm{~g} / \mathrm{cm}^{3}$

Temperatura de fusão cristalina $=66^{\circ} \mathrm{C}$

Temperatura de transição vítrea $=-32^{\circ} \mathrm{C}$

Massa molar média: $>25.000$

- Plastificante líquido: poliéster de alta massa molar (plastificante polimérico).

Densidade $=0,9 \mathrm{~g} / \mathrm{cm}^{3}$

Massa molar média $=4.000$

A seguir são mostradas as estruturas moleculares para o Elvaloy ${ }^{\circledR}$ e para o plastificante polimérico:

a) Estrutura do Elvaloy ${ }^{641}$

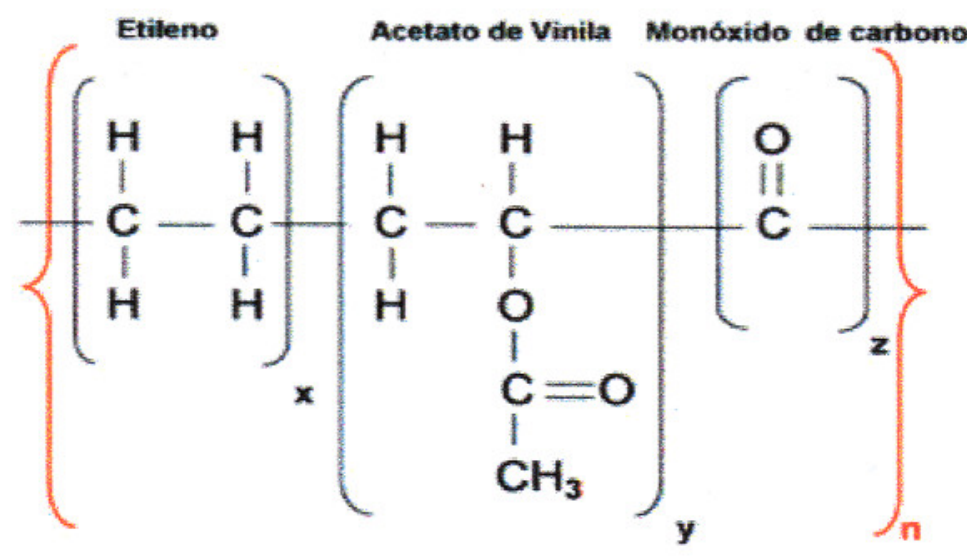

b) Estrutura simplificada de um plastificante polimérico:

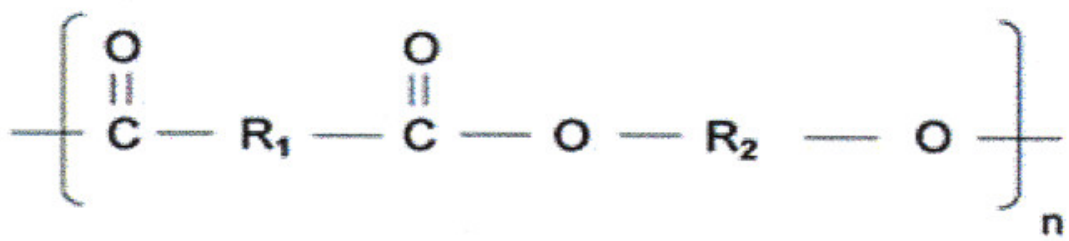

$R_{\text {: }}$ : Grupo químico proveniente do ácido carboxilico

$\mathbf{R}_{2}$ : Grupo quimico proveniente do glicol

n: Grau de polimerizaçăo 
A preparação e caracterização dos compósitos foram feitas nos laboratórios da 3M do Brasil, no Centro Nacional de Pesquisa e Desenvolvimento de Instrumentação Agropecuária (EMBRAPA), no Instituto de Física de São Carlos (IFSC-USP) e na UNESP-Presidente Prudente.

\subsection{2 - Métodos}

4.2.2.1 - Preparação dos corpos de prova

\section{ROTA EXPERIMENTAL.}

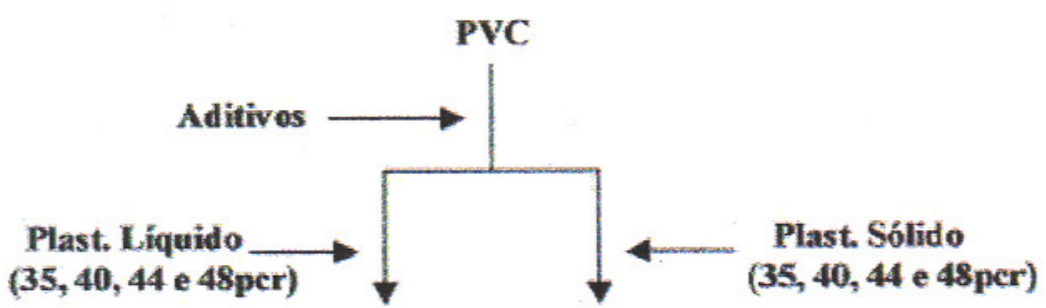

Matrix A

Matria $B$ Ensaios mecânícos, DSC, TGA

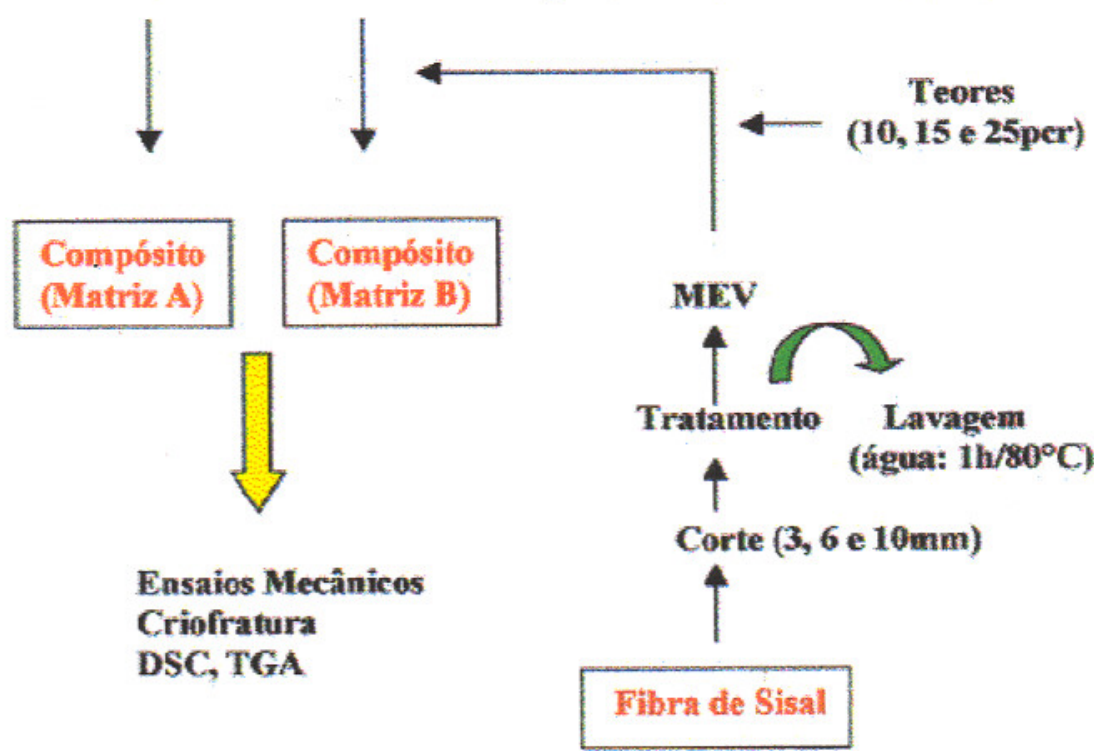


4.2.2.2 - Corte das fibras de sisal nas dimensões 3, 6 e 10mm:

As fibras foram atadas em toda a sua extensão, usando fita adesiva formando feixes de diâmetro aproximado de $5 \mathrm{~cm}$ e comprimento aproximado de 1 metro. Usando guilhotina manual, os feixes foram cortados transversalmente de acordo com o tamanho de fibra desejado $(3 \mathrm{~mm}, 6 \mathrm{~mm}$ e $10 \mathrm{~mm})$.

\subsubsection{3 - Método de tratamento das fibras de sisal:}

O método usado foi a lavagem com água na seguinte condição: 1 hora a $80^{\circ} \mathrm{C}$ com posterior lavagem com água fria. As fibras lavadas foram secas em estufa a $60^{\circ} \mathrm{C}$ por 6 horas.

Este tratamento visa a eliminação de resíduos de processamento das fibras de sisal, aumentando a eficiência do contato entre as fibras e as matrizes poliméricas em estudo.

\subsubsection{4 - Microscopia eletrônica de varredura (MEV)}

Utilizou-se um microscópio eletrônico marca ZEISS modelo DSM 960, com um feixe de elétrons de $10 \mathrm{KV}$ e $20 \mathrm{KV}$ e ampliação entre $100 \mathrm{x}$ e $3000 \mathrm{x}$. As amostras foram colocadas sobre suporte de alumínio e fixadas nas bordas com tinta prata. Sobre as amostras foi depositado uma camada de ouro "sputter coater" (plasma de argônio) marca BALZERS modelo SCD 50.

Através da técnica de microscopia eletrônica de varredura (MEV), analisouse tanto a superficie das fibras tratadas, quanto a interface fibra tratada/matriz polimérica, após criofratura de compósitos. Foram feitas fotos em diferentes aumentos, após observação de diferentes áreas de cada uma das amostras, escolhendo uma região que represente o comportamento das amostras como um todo. 
4.2.2.5 - Formulação, e condições de processo das amostras:

- Formulação: todas as matérias-primas componentes de cada uma das matrizes poliméricas em estudo, foram feitas em misturador intensivo fabricado pela Mecanoplast, Modelo Mixtruder ML-9. A adição das fibras para preparação dos compósitos, foi feita diretamente no processo de calandragem que será descrito a seguir.

- Processamento: Após a mistura dos componentes conforme descrito acima, as formulações foram processadas em calandra de laboratório (tipo misturador de dois rolos com disposição horizontal), fabricada pela Mecanoplast, Modelo $C$ 400-2S. As fibras de sisal, foram adicionadas durante a calandragem de cada uma das matrizes para obtenção dos compósitos. Foram confeccionadas também amostras das matrizes puras (sem fibra), para análise comparativa. Mantas de espessura $2,4+/-0,3 \mathrm{~mm}$ foram tiradas diretamente da calandra ao final do processo descrito abaixo.

- Condições de processo: Misturador intensivo - temperatura $=80^{\circ} \mathrm{C}+/-5^{\circ} \mathrm{C} /$ tempo $=5 \mathrm{~min} ;$ Calandragem - temperatura $=170^{\circ} \mathrm{C}+/-5^{\circ} \mathrm{C} /$ tempo $=10+/-2$ $\min$.

\subsubsection{6 - Análises térmicas (TGA e DSC)}

A análise termogravimétrica (TGA) consiste em uma técnica termoanalítica na qual a massa de uma amostra é medida em função do tempo com a temperatura constante ou em função de programação controlada de temperatura [54]. Neste trabalho utilizou-se o método dinâmico, sendo a amostra submetida a uma variação constante de temperatura em um forno, enquanto a massa é monitorada por uma termobalança. 
As curvas termogravimétricas foram obtidas com amostras de compostos de PVC plastificados com plastificante líquido e com plastificante sólido, com e sem a adição de fibras de sisal. A amostra pura do copolímero Elvaloy ${ }^{\circledR}$ também foi analisada. As condições do ensaio foram as seguintes:

- Faixa de temperatura: $25^{\circ} \mathrm{C}$ a $600^{\circ} \mathrm{C}$

- Taxa de aquecimento: $10^{\circ} \mathrm{C} / \mathrm{min}$

- Atmosfera: $\mathrm{N}_{2}$ como gás de arraste (fluxo: $15 \mathrm{ml} / \mathrm{min}$ )

- Equipamento: NETZSCH modelo TG 209

$\mathrm{Na}$ calorimetria exploratória diferencial (DSC), a amostra e um material de referência são igualmente submetidos a uma programação de temperatura, enquanto se medem as transformações de calor que ocorrem na amostra. Deste modo, o DSC mede a entalpia de uma transformação ocorrida na amostra (reação química, mudança de fase cristalina, fusão, volatilização, etc...) durante um aquecimento programado [54]. As mesmas amostras do item anterior foram analisadas para obtenção das curvas de DSC. As condições de ensaio foram as seguintes:

- Faixa de temperatura: $-100^{\circ} \mathrm{C}$ a $300^{\circ} \mathrm{C}$

- Taxa de aquecimento: $10^{\circ} \mathrm{C} / \mathrm{min}$

- Atmosfera: $\mathrm{N}_{2}$ como gás de arraste (fluxo: $30 \mathrm{ml} / \mathrm{min}$ )

- Equipamento: NETZSCH modelo DSC 204 
4.2.2.7 - Ensaio mecânico de tração

Todas as amostras foram preparadas a partir de mantas obtidas em misturador de dois rolos (ou calandra de dois rolos dispostos horizontalmente), conforme já descrito anteriormente. Os corpos de prova foram cortados usando matriz para estampagem tipo gravata em uma prensa hidráulica manual. Os ensaios foram realizados segundo norma ASTM D412-98 método A, usando máquina de tração EMIC, modelo DL $500 \mathrm{MF}$. 


\section{5- RESULTADOS E DISCUSSÃo}

\section{1 - Corte e tratamento das fibras de sisal}

Com o objetivo de se verificar a eficiência da metodologia de corte empregada neste trabalho, foram tomadas em torno de 300 fragmentos de fibra de cada um dos 3 tamanhos nominais escolhidos para estudo, e com uma lupa graduada Bausch \& Lomb determinou-se o comprimento de cada fragmento. A distribuição obtida encontra-se na Figura 5.1.

A escolha dos tamanhos de fibra para análise neste trabalho se baseou em referências encontradas na literatura $[3,28,55]$ onde a maioria dos compósitos com matriz termoplástica estudados, apresentou melhorias em suas propriedades quando as fibras de sisal eram empregadas em fragmentos compreendidos no tamanho médio de $6 \mathrm{~mm}$. Escolheu-se, portanto, além do comprimento de $6 \mathrm{~mm}$, as medidas de $3 \mathrm{~mm}$ (abaixo) e 10mm (acima).

Com relação ao tratamento das fibras de sisal utilizadas neste trabalho, consideraram-se referências da literatura $[38,56]$ onde estudos mostram que, para compósitos de PVC plastificado, tratamentos térmicos, acetilação e agentes de acoplagem pouco afetam a interação fibra-matriz, não produzindo efeitos positivos nas propriedades mecânicas dos compósitos. Ao contrário, fibras de sisal não tratadas e usadas como reforço em matriz de PVC resultaram em melhores propriedades mecânicas dos compósitos [38,56]. Baseado nestas informações decidiu-se apenas 
pela lavagem das fibras com água a $80^{\circ} \mathrm{C}$ para remover possiveis resíduos de processamento das fibras conforme descrito anteriormente.

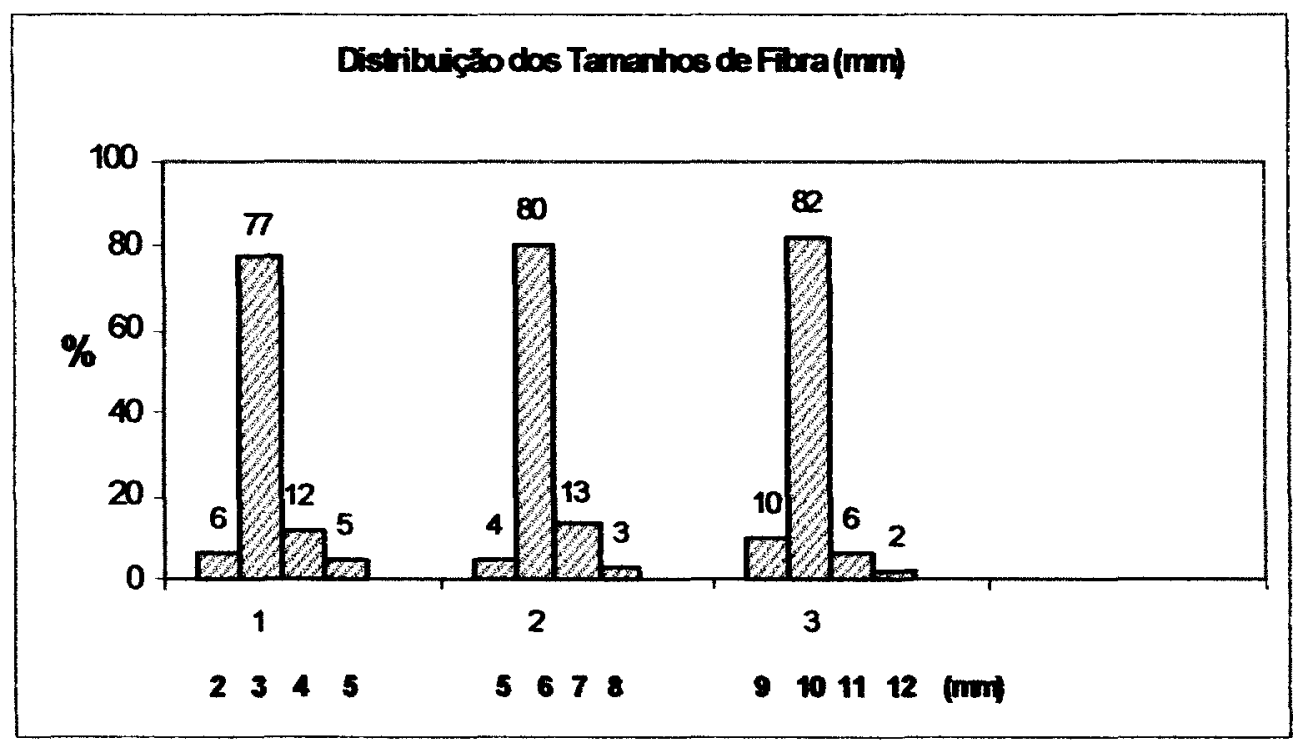

Figura 5.1 - Distribuição percentual dos tamanhos de fibra obtidos para cada um dos três tamanhos nominais escolhidos (conjunto de valores $1=3 \mathrm{~mm}$ nominal, conjunto de valores $2=6 \mathrm{~mm}$ nominal, conjunto de valores $3=10 \mathrm{~mm}$ nominal).

\section{2 - Processabilidade dos compostos}

Considerando a matriz tipo B, onde o copolimero Elvaloy ${ }^{\circledR}$ foi usado como plastificante, observou-se (nas condições de processo estabelecidas para o experimento) uma fácil e rápida incorporação deste plastificante à resina de PVC. Esta observação é baseada na aparência do composto durante o processamento, que passa rapidamente de um aspecto opaco a um aspecto transparente e brilhante [45]. Isto foi observado para todos os niveis de plastificação estudados. Considerando-se a adição de fibras de sisal a este tipo de matriz polimérica, também observou-se uma fácil incorporação das mesmas. 
As mesmas observações anteriores são válidas para a matriz tipo A onde, um plastificante líquido polimérico foi usado na plastificação do PVC.

\section{3 - Microscopia eletrônica de varredura (MEV)}

Foram feitos dois estudos: O primeiro, para verificar o efeito do tratamento das fibras (lavagem com água quente), comparando com a fibra não lavada. $\mathrm{O}$ segundo, verificando o aspecto de criofratura dos compósitos (fratura em nitrogênio líquido) constituídos pelas duas matrizes em estudo (Tipos A e B, conforme definição anterior).

Analisando as micrografias para as fibras lavadas e não lavadas (figuras 5.2, $5.3,5.4$ e 5.5), nota-se que a lavagem com água quente remove boa parte dos resíduos de processamento superficiais que podem prejudicar o contato fibra-matriz.

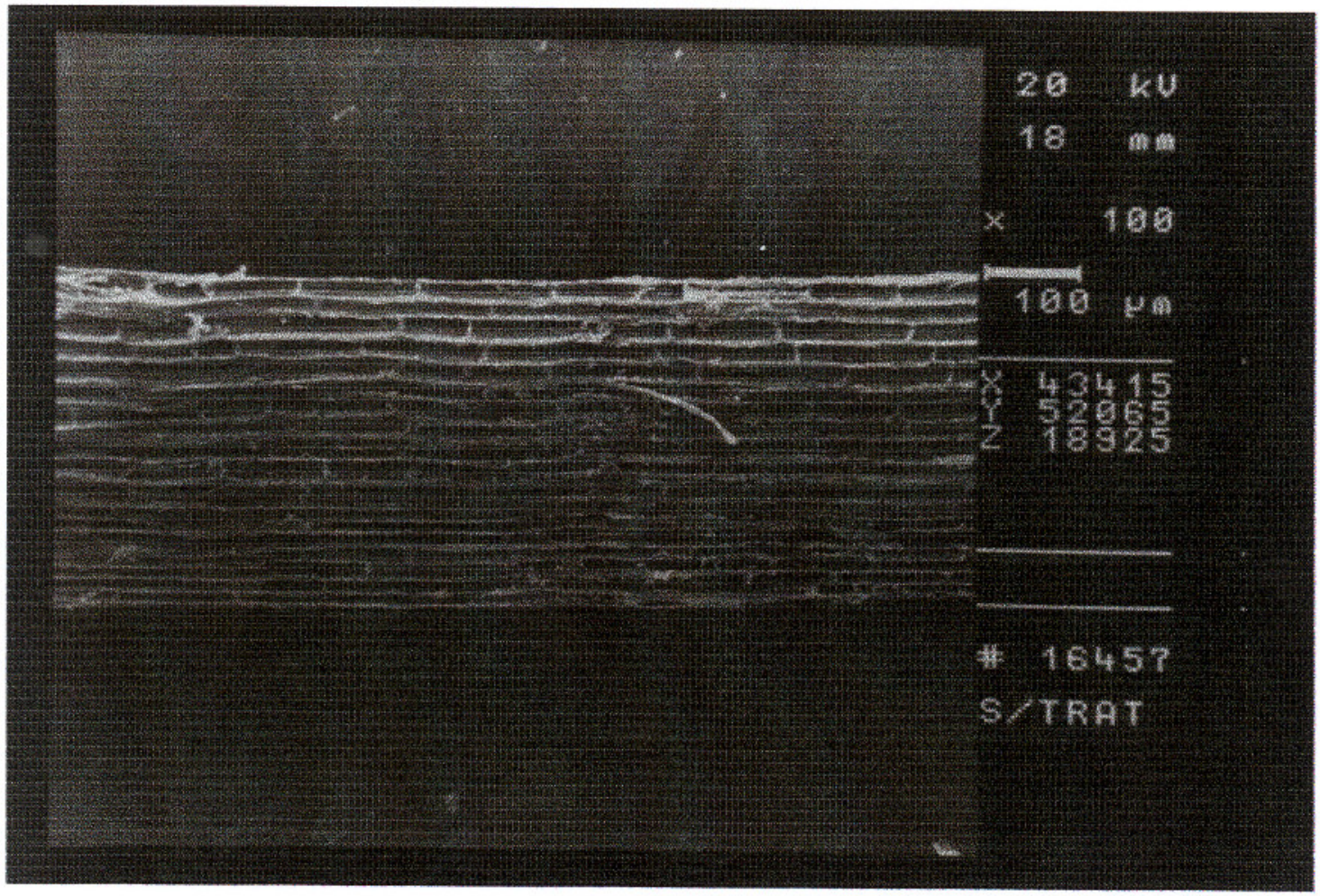

Figura 5.2 - Fotografia obtida por MEV da superficie de fibra de sisal sem tratamento. Ampliação 100x. 


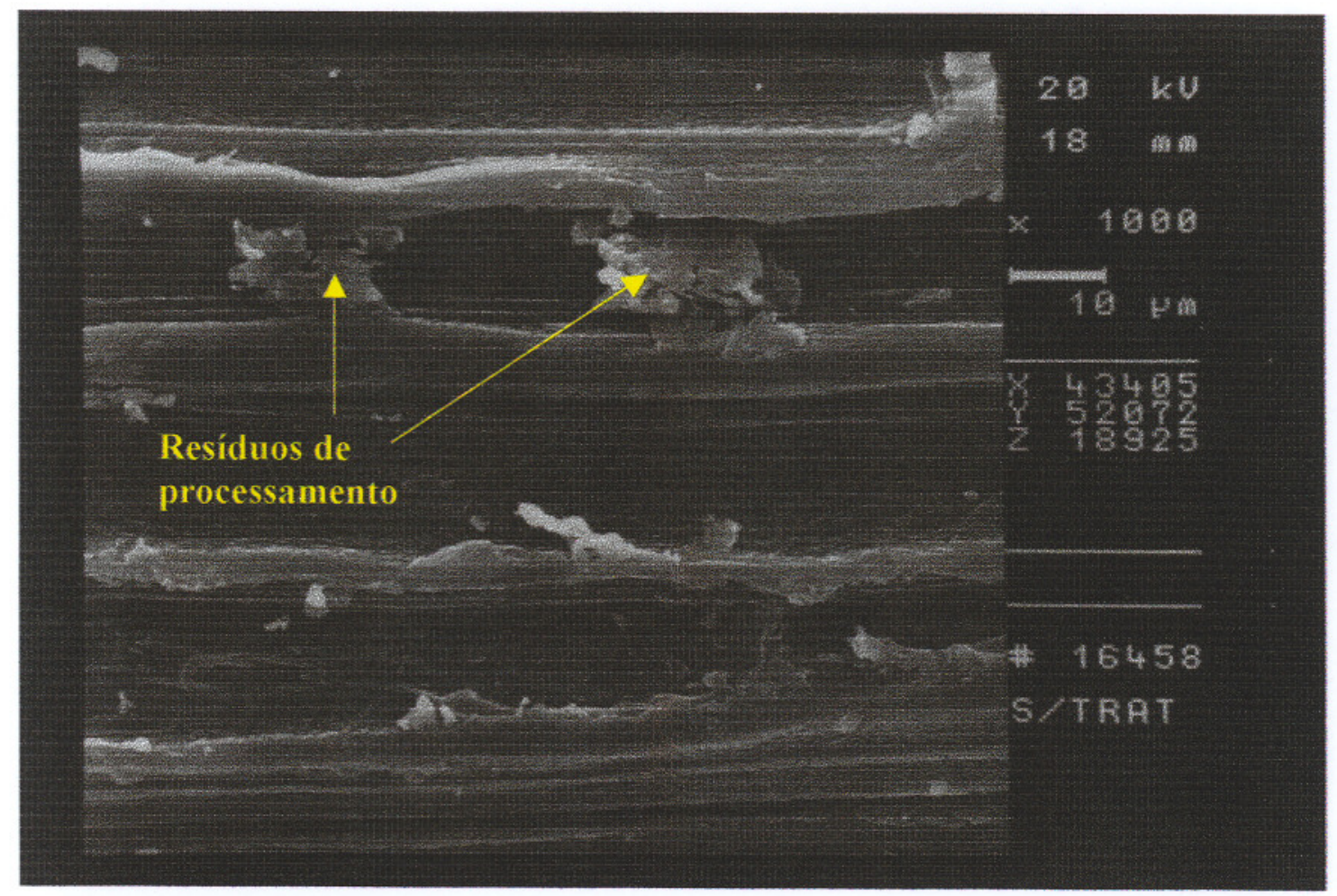

Figura 5.3 - Fotografia obtida por MEV da superficie de fibra de sisal sem tratamento. Ampliação 1000x.

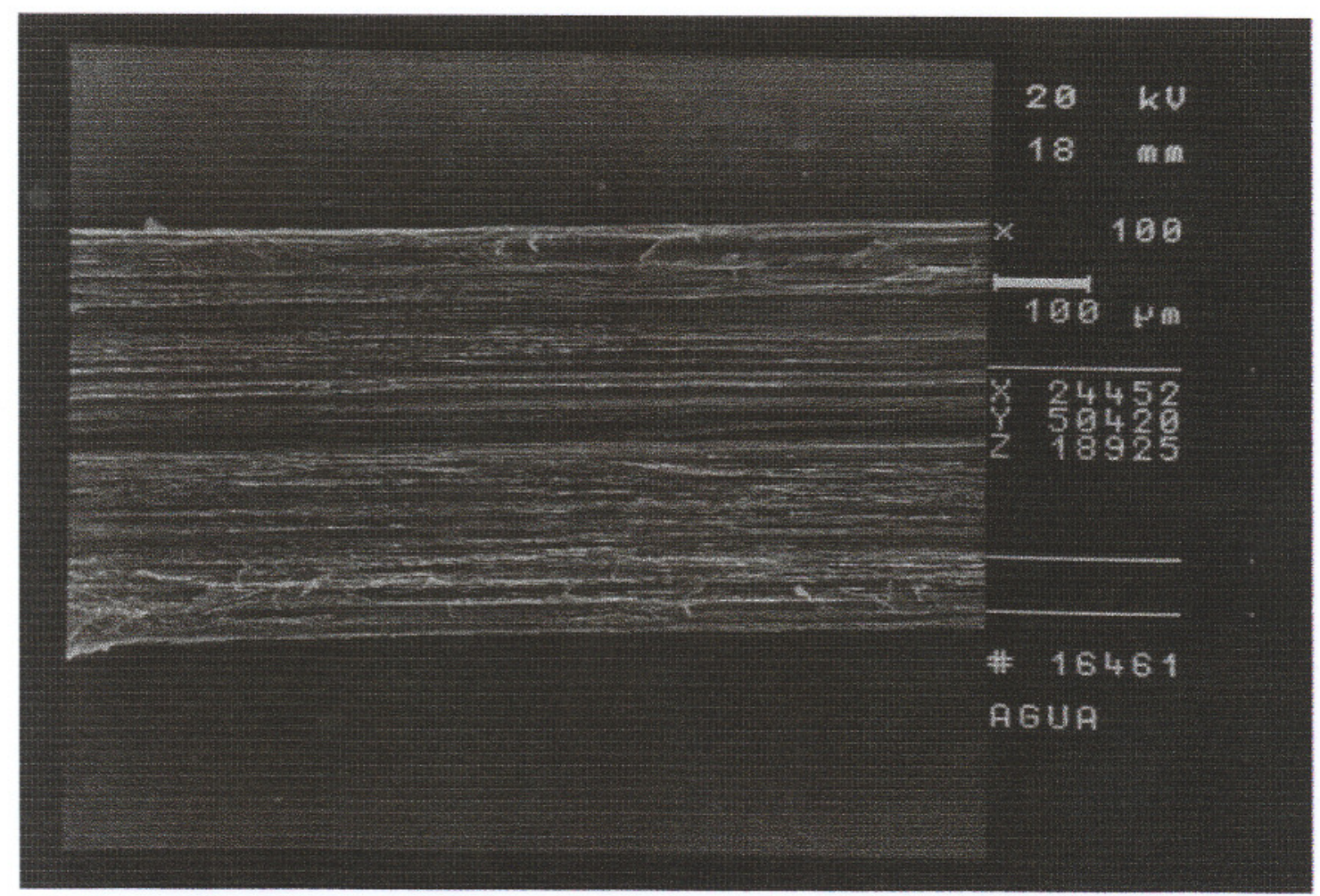

Figura 5.4 - Fotografia obtida por MEV da superficie da fibra de sisal após lavagem com água quente $\left(80^{\circ} \mathrm{C}\right.$ por 1 hora). Ampliação $100 \mathrm{x}$. 


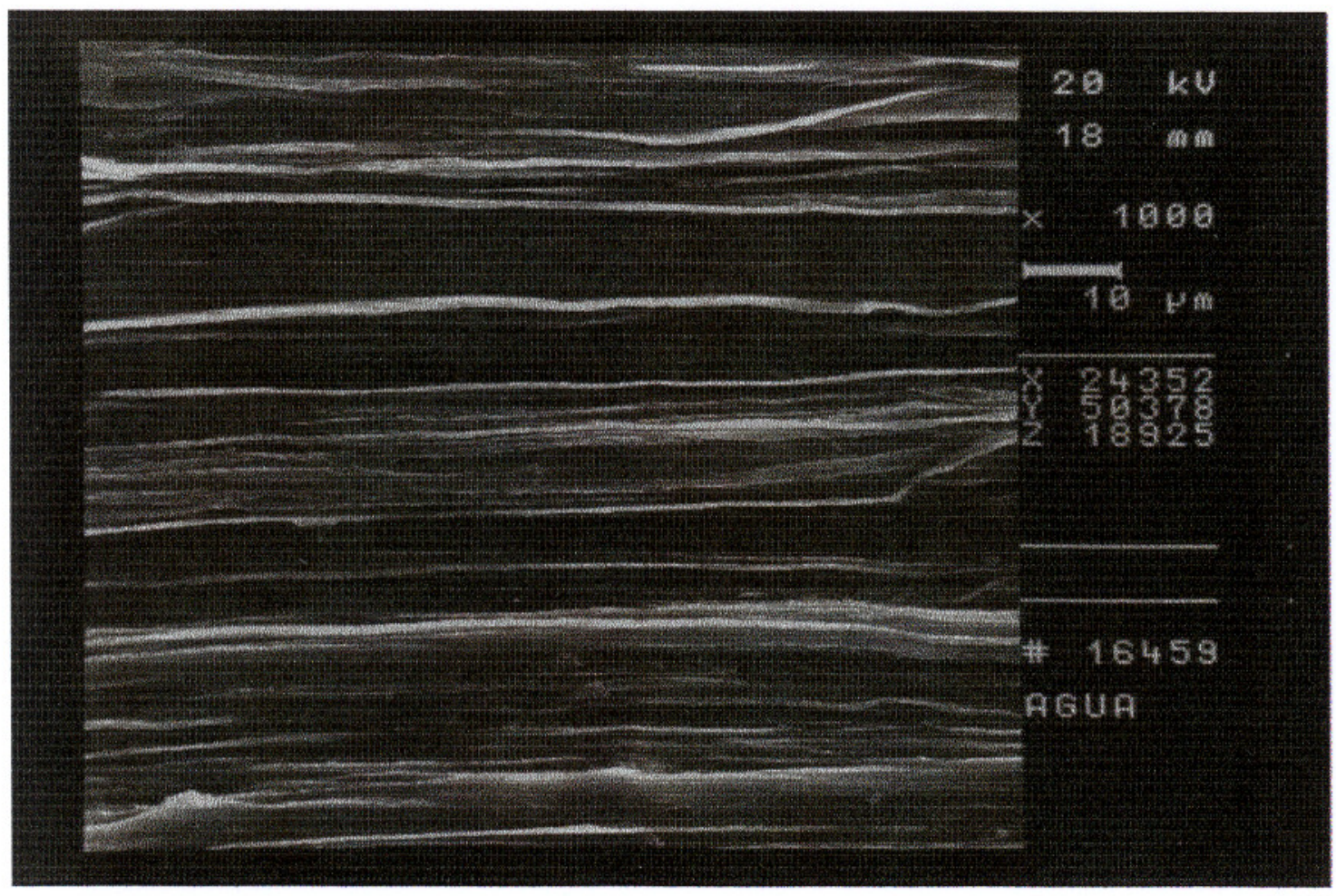

Figura 5.5 - Fotografia obtida por MEV da superficie da fibra de sisal após lavagem com água quente $\left(80^{\circ} \mathrm{C}\right.$ por 1 hora). Ampliação $1000 \mathrm{x}$.

As micrografias a seguir (figuras 5.6 e 5.7), representam o aspecto de criofratura (fratura em nitrogênio líquido) para os compósitos formados pelas matrizes tipos A e B, carregadas com 15pcr de fibra de sisal lavadas nas condições descritas anteriormente.

Observa-se que as fibras de sisal têm uma maior área de contato com a matriz do tipo B (Figura 5.7), constituída pelo PVC plastificado com o plastificante sólido (Elvaloy ${ }^{\circledR}$ ) quando se compara com a matriz do tipo A (Figura 5.6), constituída pelo PVC plastificado com plastificante líquido. Um melhor contato fibra-matriz, em geral, leva a uma melhoria das propriedades mecânicas. 


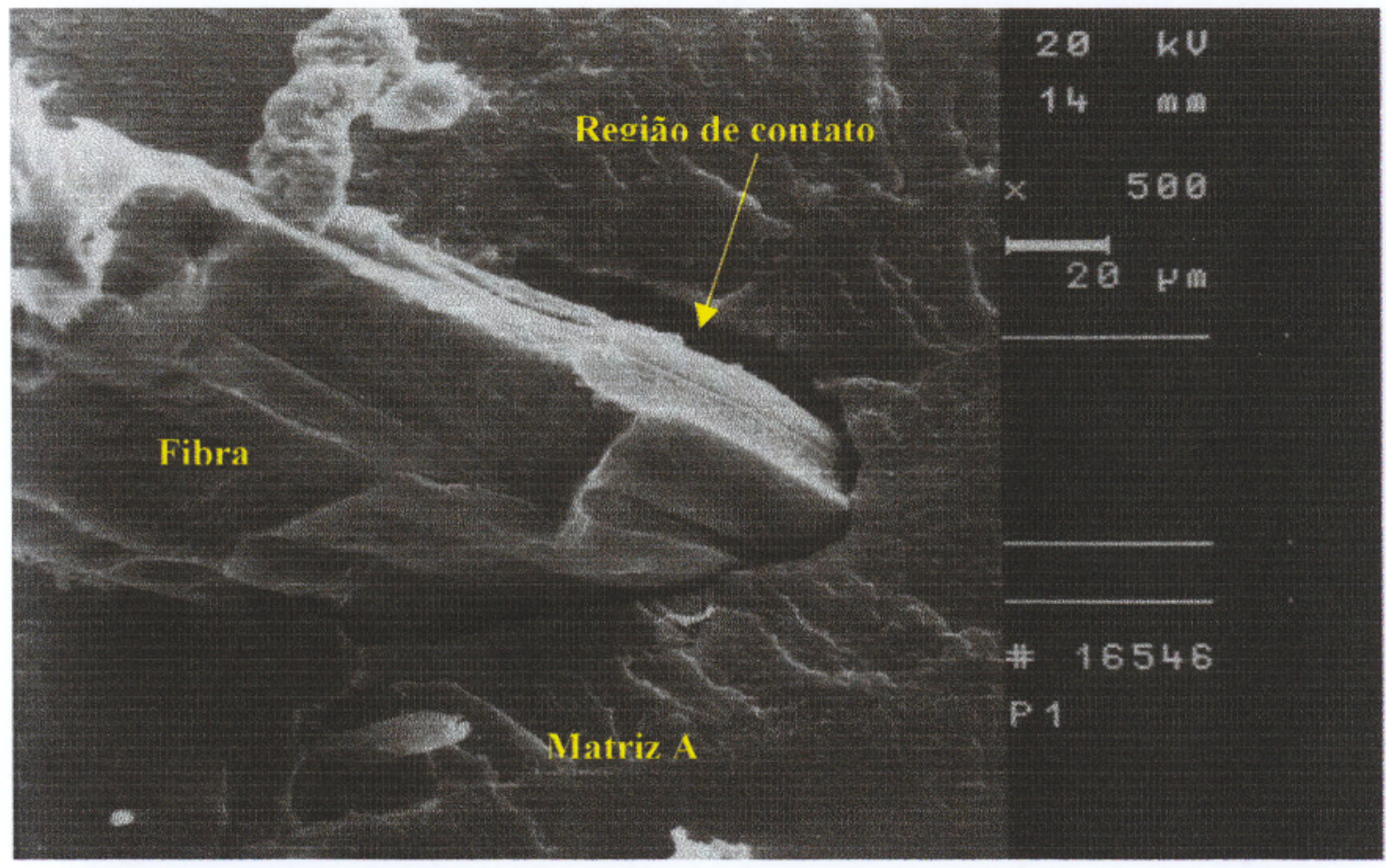

Figura 5.6 - Fotografia obtidas por MEV do aspecto de fratura do compósito feito a partir de matriz do tipo A (Resina PVC com plastificante líquido carregada com 15 pcr de fibras de Sisal). Ampliação 500x.

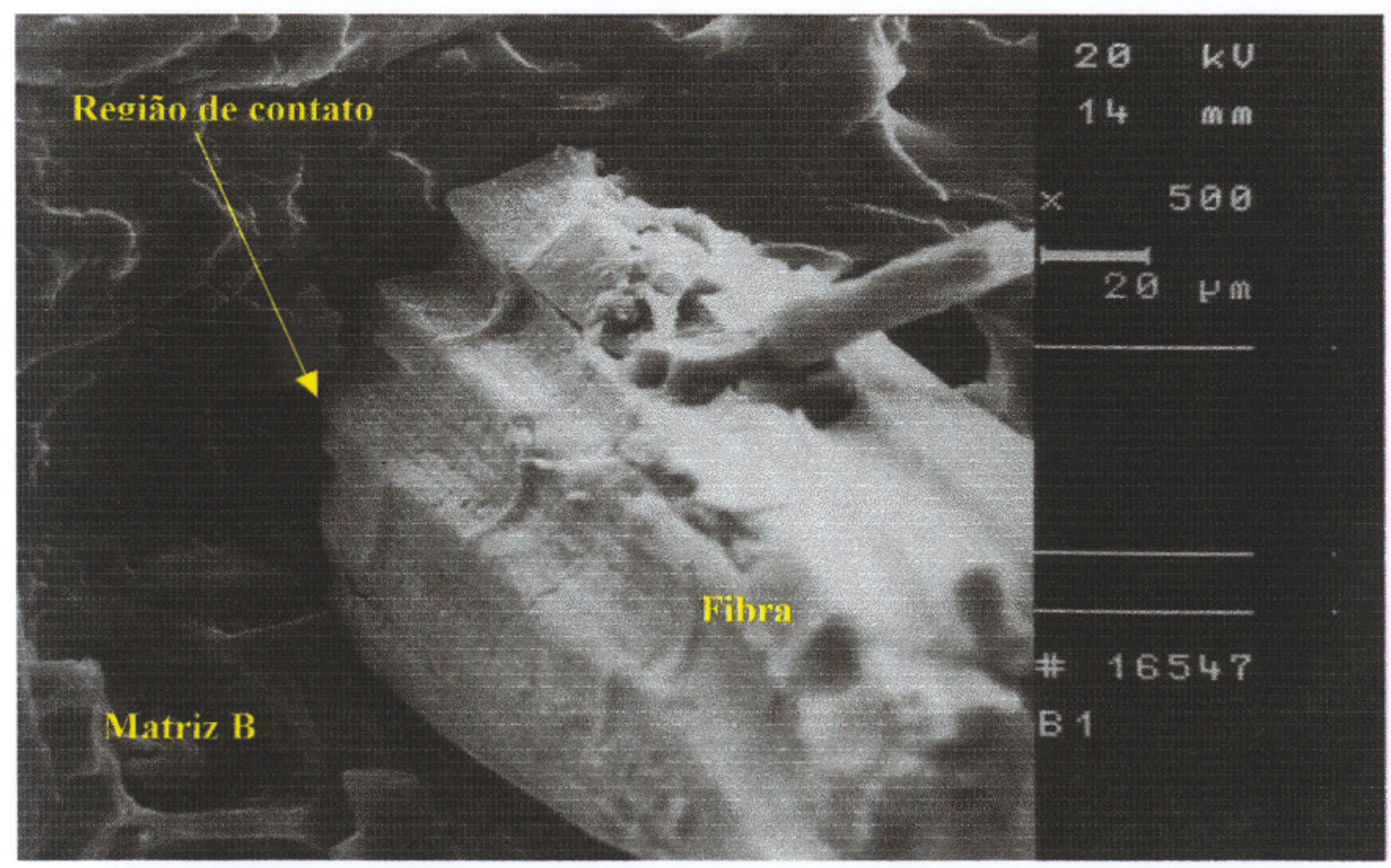

Figura 5.7 - Fotografias obtidas por MEV do aspecto de fratura do compósito feito a partir de matriz do tipo B (Resina PVC com plastificante sólido, carregada com 15 pcr de fibras de Sisal). Ampliação 500x. 
Com objetivo de confirmar as observações anteriores, novos ensaios de MEV foram feitos após criofratura de compósitos constituídos por matrizes dos tipos $\mathrm{A}$ e B, comparando diferentes teores de plastificante (35pcr e 48pcr) e com um maior teor de fibra de sisal (25pcr). As fibras de sisal foram tratadas na mesma condição descrita anteriormente.

As figuras 5.8 e 5.9, comparam o aspecto de criofratura das matrizes tipos A e B (cada uma com 35pcr de plastificante e 25pcr de sisal). As figuras 5.10 e 5.11 comparam o aspecto da criofratura das matrizes tipos A e B, agora com um maior teor de plastificante (cada uma com 48pcr de plastificante e $25 \mathrm{pcr}$ de fibra de sisal).

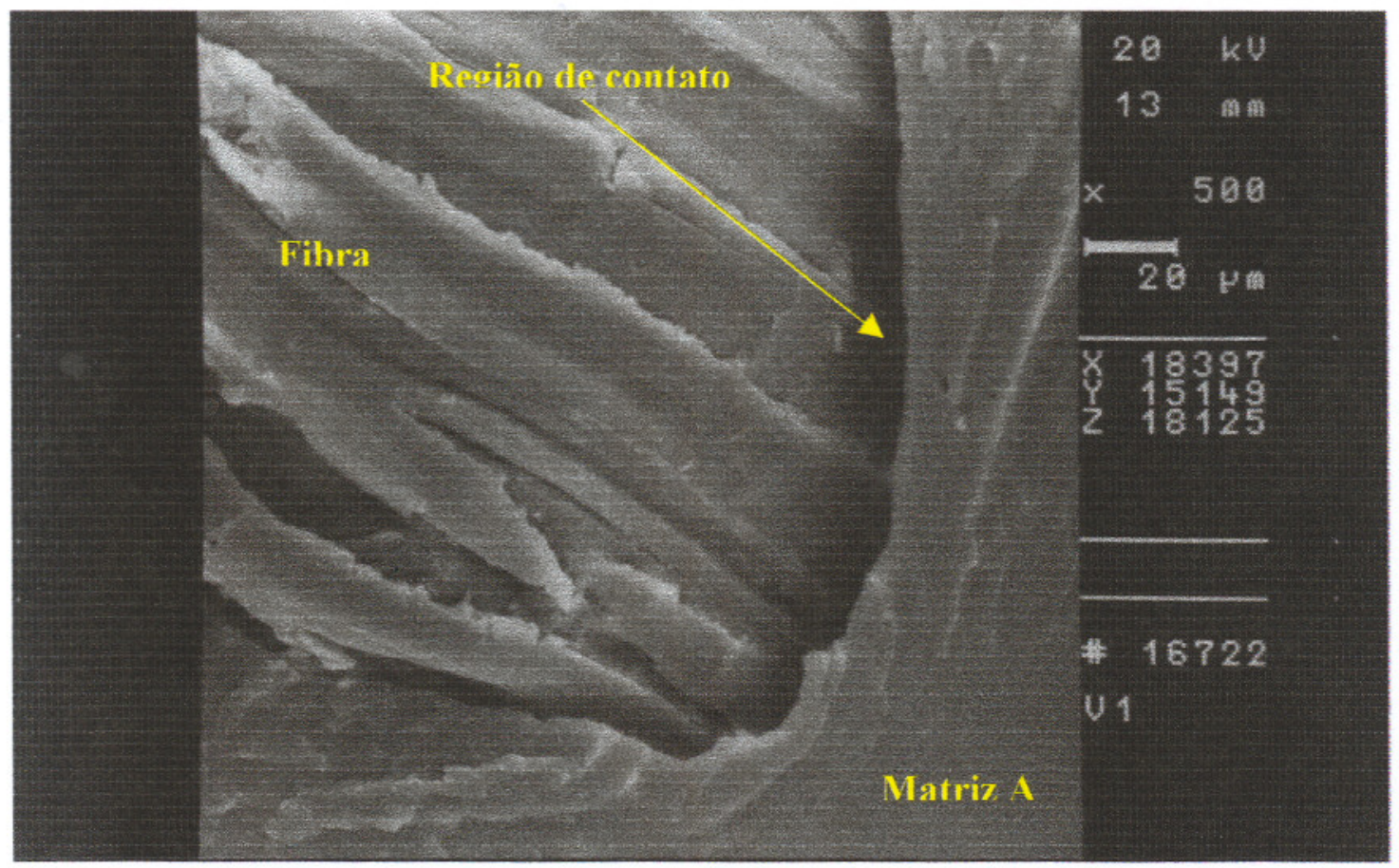

Figura 5.8- Fotografia obtida por MEV do aspecto de fratura de compósito feito a partir de matriz tipo A (resina PVC com 35pcr de plastificante líquido e 25pcr de sisal). Ampliação 500x. 


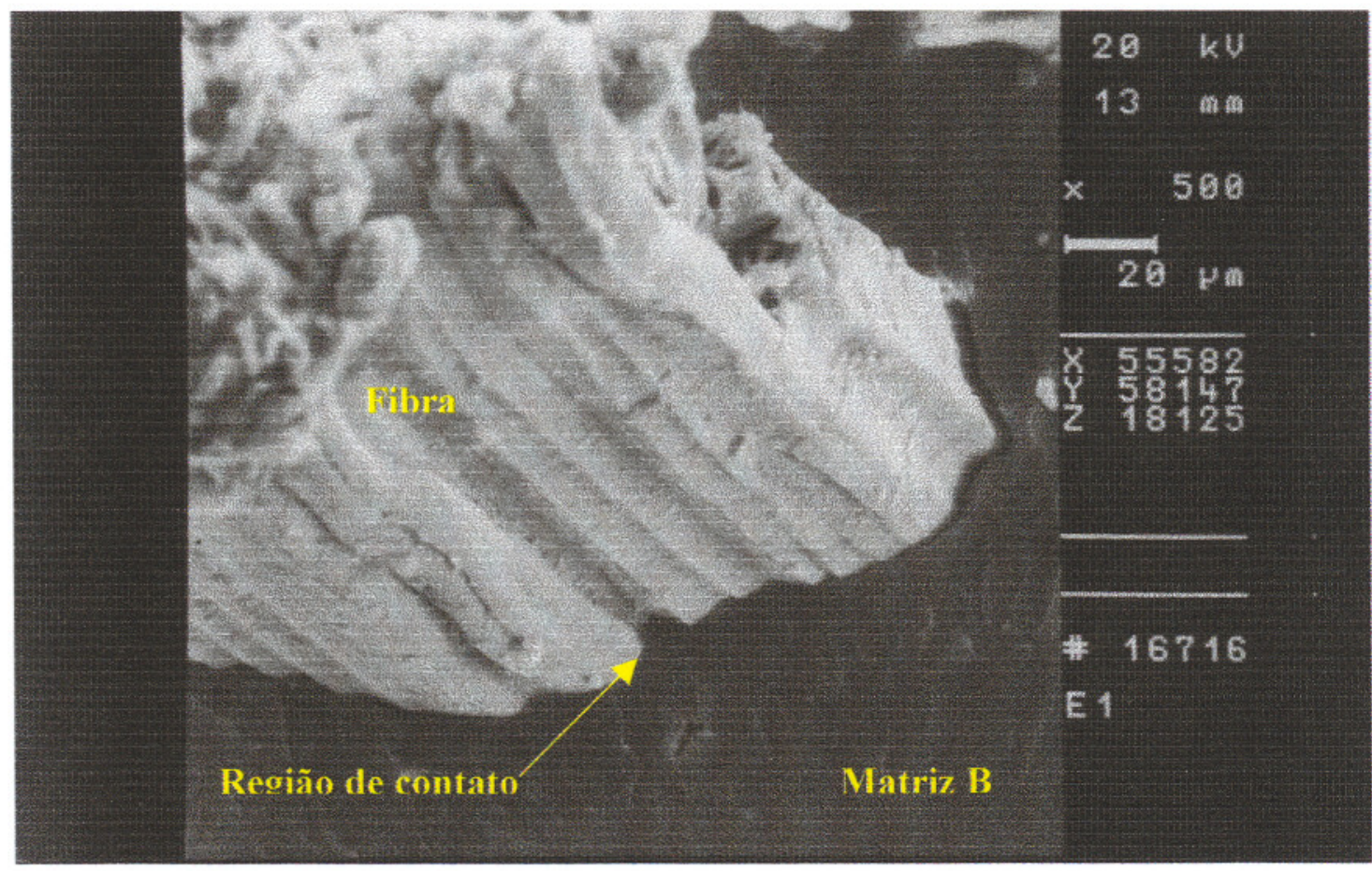

Figura 5.9- Fotografia obtida por MEV do aspecto de fratura de compósito feito a partir de matriz tipo B (resina PVC com 35 pcr de plastificante sólido Elvaloy ${ }^{\circledR}$ e 25pcr de sisal). Ampliação 500x.

Comparando-se os diferentes teores de plastificante, novamente pode-se observar que as fibras de sisal apresentam uma maior molhabilidade com a matriz polimérica tipo B $\left(\mathrm{PVC}+\right.$ plastificante sólido Elvaloy $\left.{ }^{\circledR}\right)$, quando comparadas com a matriz tipo A (PVC + plastificante líquido). Isto ocorre tanto para o menor teor de plastificação (figuras 5.8 e 5.9) quanto para maiores teores (figuras 5.10 e 5.11).

Quando comparamos as micrografias das figuras 5.9 e 5.11, observa-se que o aumento do teor de plastificante sólido Elvaloy ${ }^{\circledR}$ de 35 pcr para 48pcr para a matriz tipo B, melhora a molhabilidade das fibras pela matriz polimérica. Isto não foi observado quando se aumenta o teor de plastificante líquido nas mesmas proporções para a matriz A (figuras 5.8 e 5.10). 


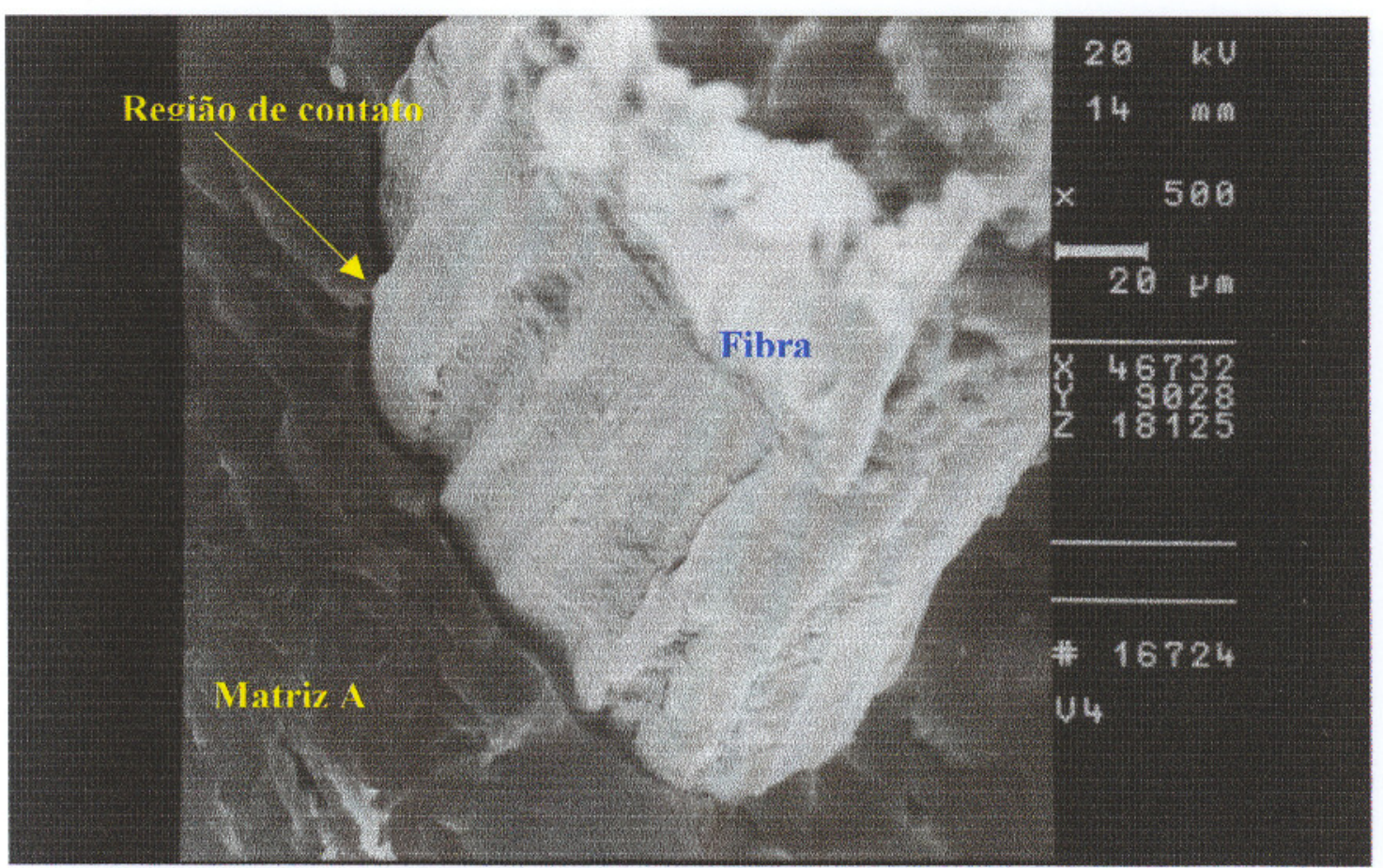

Figura 5.10 - Fotografia obtida por MEV do aspecto de fratura de compósito feito a partir de matriz tipo A (resina PVC com 48pcr de plastificante líquido e $25 \mathrm{pcr}$ de sisal). Ampliação 500x.

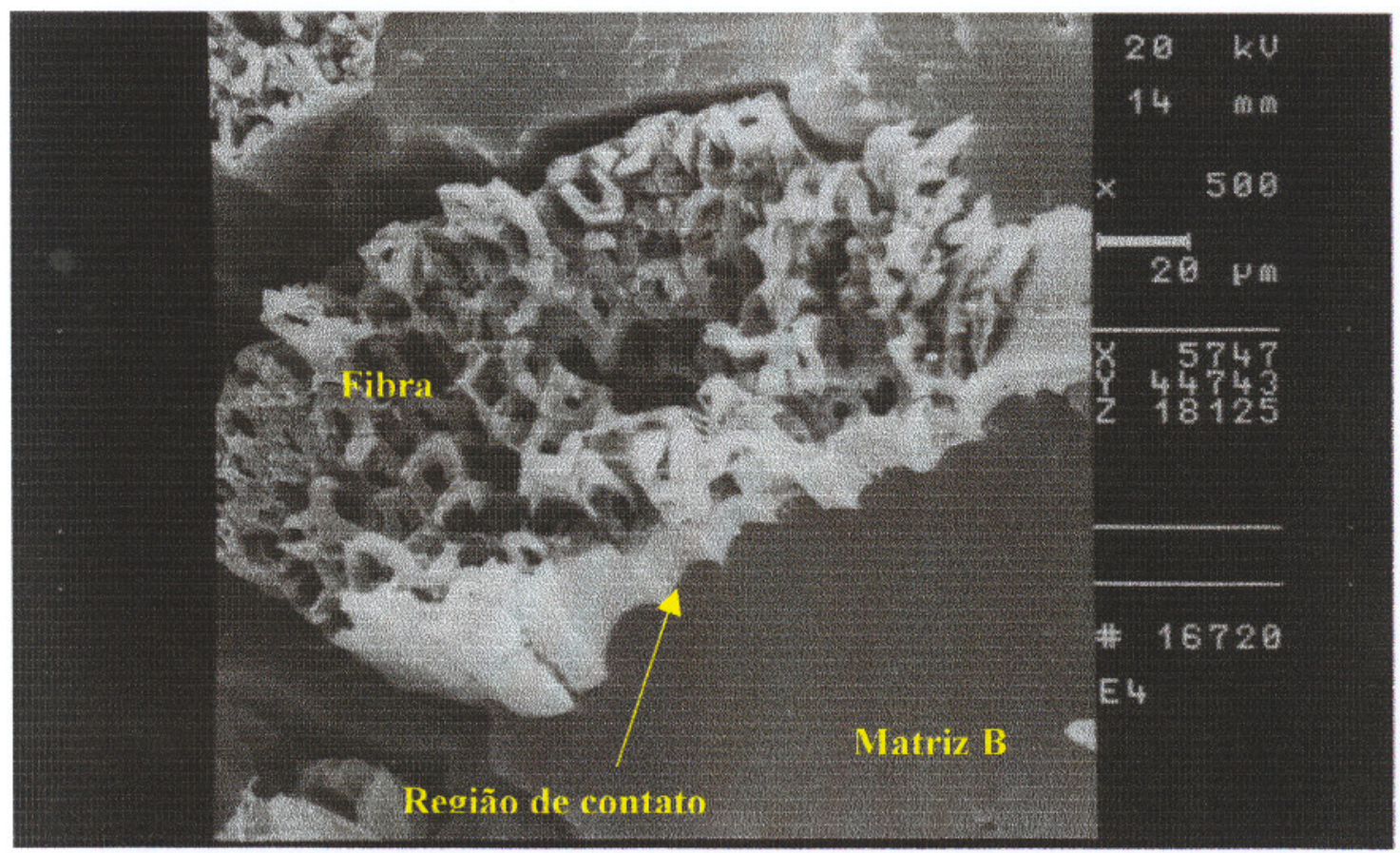

Figura 5.11 - Fotografia obtida por MEV do aspecto de fratura de compósito feito a partir de matriz tipo B (resina PVC com 48pcr de plastificante sólido Elvaloy ${ }^{\circledR} \mathrm{e}$ 25pcr de sisal). Ampliação 500x. 
Espera-se que uma melhor molhabilidade e contato fibra-matriz possam contribuir para uma melhoria das propriedades mecânicas dos compósitos formulados a partir de matrizes poliméricas do tipo B, quando comparados com compósitos formulados a partir de matrizes do tipo A. Isto é esperado, pois segundo alguns trabalhos da literatura $[39,57]$, quanto maior a interação fibra-matriz, maior é a resistência mecânica do compósito.

\section{4 - Ensaios de tração}

\subsection{1 - Variação do tamanho de fibra de sisal nos compósitos}

Com o objetivo de determinar o melhor tamanho de fibra de sisal para cada uma das matrizes em estudo (tipos A e B), foram preparados compósitos utilizando tamanhos de fibra de $3 \mathrm{~mm}, 6 \mathrm{~mm}$ e $10 \mathrm{~mm}$. O teor de fibra foi de $15 \mathrm{pcr}$ e o teor de plastificante (tanto líquido quanto sólido) foi de 40pcr. Estes teores foram escolhidos por serem intermediários às faixas escolhidas para estudo neste trabalho. Foram então realizados ensaios de tração para determinação da resistência à ruptura, elongação e módulo elástico (módulo a 10\% de elongação-região elástica).

As figuras $5.12,5.13$ e 5.14, mostram o comportamento relativo entre as matrizes A e B em função do tamanho das fibras de sisal. Para ambas as matrizes, a adição de fibra provoca uma redução nos valores de tensão de ruptura e elongação e um aumento no módulo elástico. Com relação ao tamanho de fibra de sisal, $6 \mathrm{~mm}$ apresentou um comportamento melhor, quando se considera o ensaio de tração, indicando uma melhor transferência da solicitação mecânica da fibra para a matriz nesta condição [55]. Para os demais ensaios (elongação e módulo), o tamanho de fibra teve pouca influência nos valores medidos. 


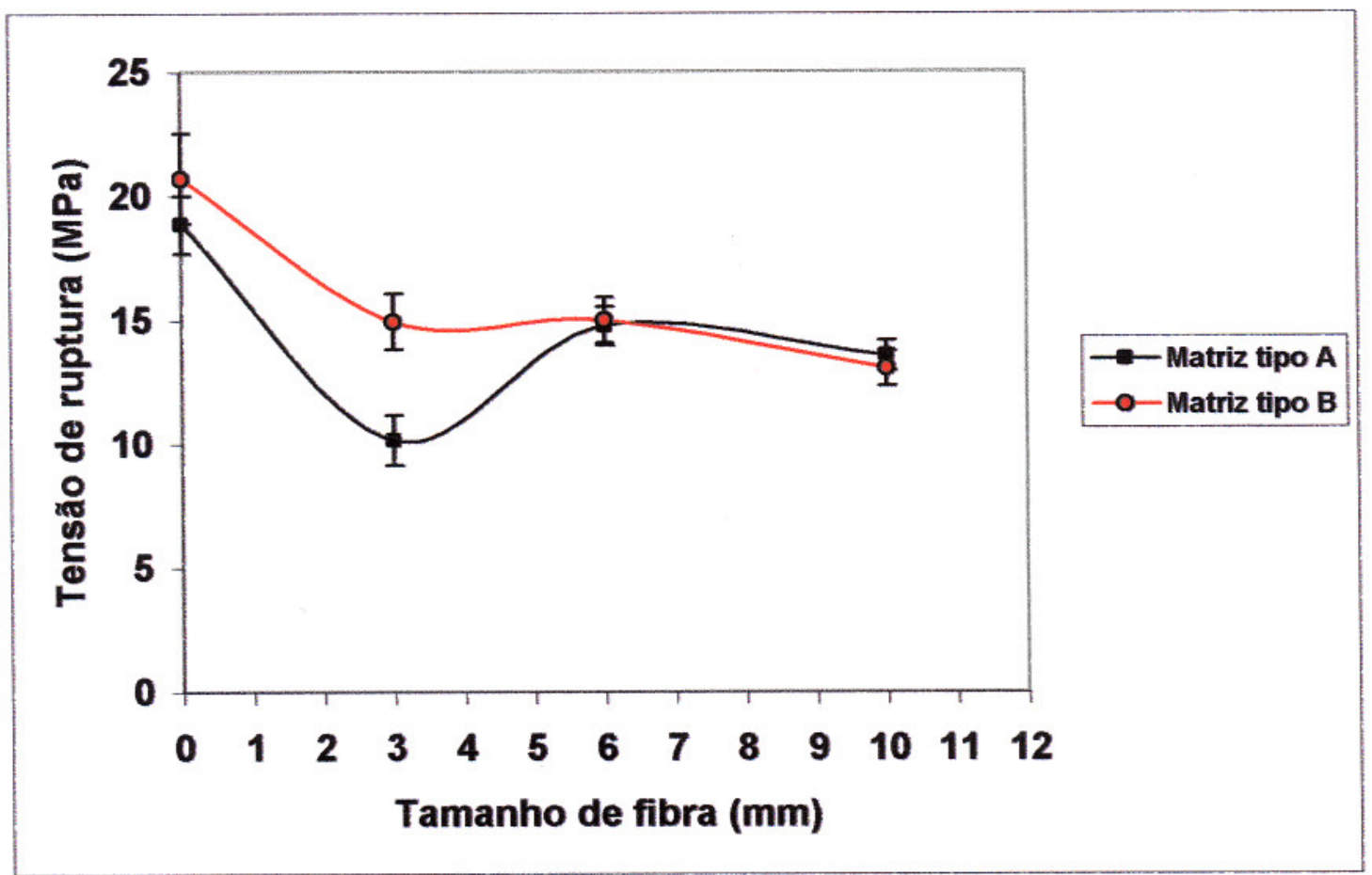

Figura 5.12 - Curvas de tensão de ruptura (MPa) versus tamanho de fibra de sisal nos compósitos tipo A (PVC + 40pcr de plastificante líquido) e tipo B (PVC +40pcr de plastificante sólido Elvaloy ${ }^{\circledR}$ ). Os compósitos apresentam 15 pcr de fibras de sisal.

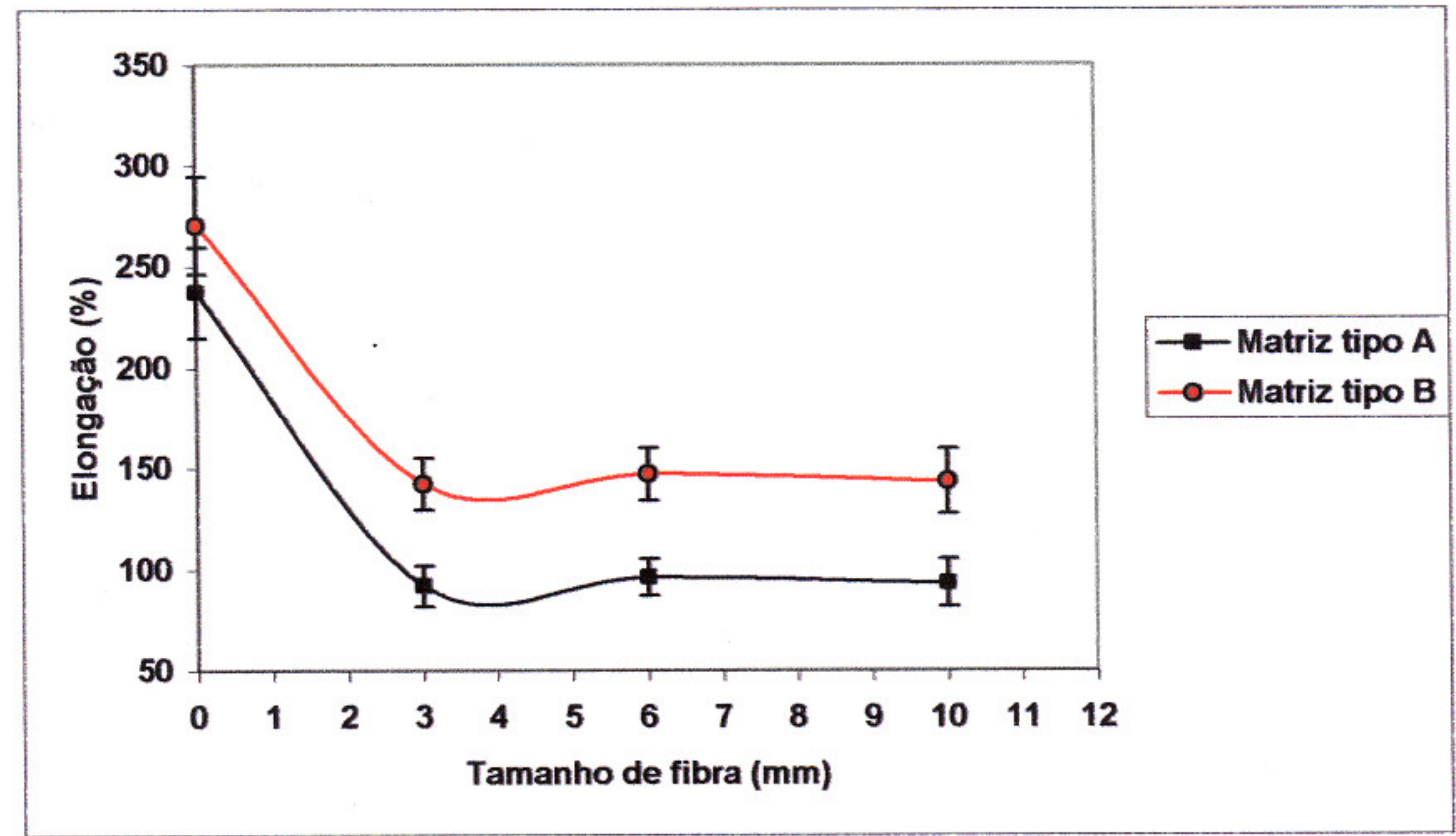

Figura 5.13 - Curvas de elongação na ruptura (\%) versus tamanho de fibra de sisal nos compósitos tipo A (PVC + 40pcr de plastificante líquido) e tipo B (PVC + 40pcr de plastificante sólido Elvaloy ${ }^{\circledR}$ ). Os compósitos apresentam $15 \mathrm{pcr}$ de fibras de sisal. 


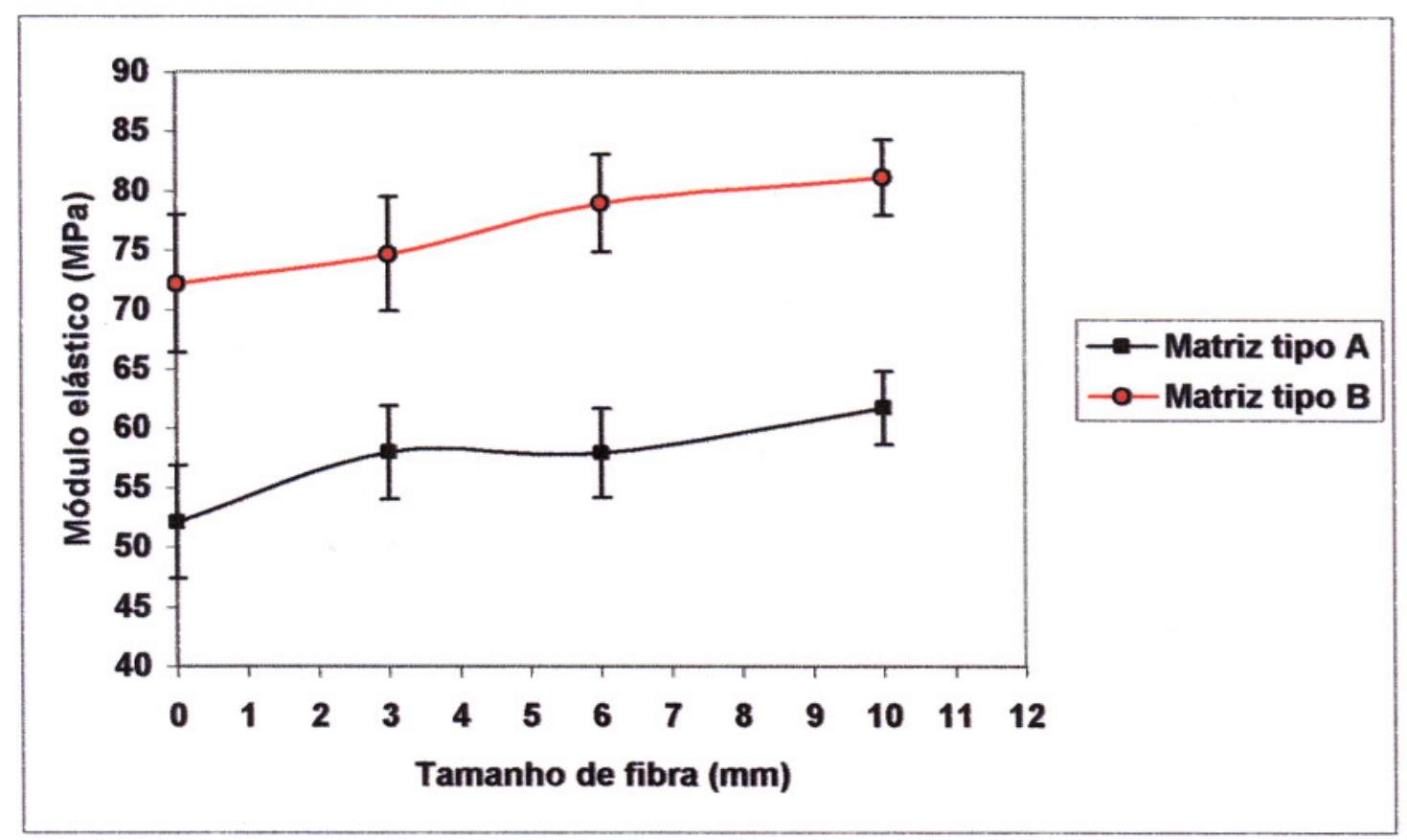

Figura 5.14 - Curvas de módulo elástico / 10\% de elongação (MPa) versus tamanho de fibra de sisal nos compósitos tipo A (PVC + 40pcr de plastificante líquido) e tipo $\mathrm{B}\left(\mathrm{PVC}+40 \mathrm{pcr}\right.$ de plastificante sólido Elvaloy $\left.{ }^{\circledR}\right)$. Os compósitos apresentam $15 \mathrm{pcr}$ de fibras de sisal.

\subsection{2 - Variação do teor de fibra de sisal nos compósitos}

De acordo com os resultados anteriores do ensaio de tração, considerou-se $6 \mathrm{~mm}$ o tamanho de fibra ideal dentre as estudadas para ambas as matrizes poliméricas. Realizou-se um novo estudo para verificar o efeito do teor de fibra de sisal nestas matrizes. Foram avaliados os teores de fibra de 10pcr, 15pcr e 25pcr em ambas as matrizes (tipos A e B). O teor de plastificante para ambas as matrizes continua sendo 40pcr, como no caso anterior do estudo para diferentes tamanhos de fibra. Foram realizados ensaios de tração para determinação da resistência à ruptura, elongação e módulo elástico (módulo a 10\% de elongação-região elástica).

As figuras $5.15,5.16$ e 5.17 , mostram o comportamento relativo entre as matrizes tipos A e B em função do teor de fibra de sisal. Considerando-se os gráficos 
de tensão e elongação na ruptura (figuras 5.15 e 5.16), observa-se que sempre ocorre uma redução nos valores destas propriedades (para ambas as matrizes, tipos A e B), quando se aumenta o teor de fibra de sisal. Observa-se também que a curva de decaimento é bastante similar para ambas as matrizes. Este comportamento tem sido observado na literatura para vários sistemas $[26,32]$.

Quando se considera o módulo elástico (figura 5.17), observa-se um aumento dos valores com o aumento do teor de fibra de sisal para ambas as matrizes em estudo, sendo que ambas as curvas têm comportamento similar.

Até o momento, considerando-se as formulações estudadas (matrizes com 40 pcr de plastificante), foi possivel identificar uma vantagem da matriz tipo B (Blenda PVC/ Elvaloy ${ }^{\circledR}$ ) sobre a matriz tipo A (PVC/ plastificante líquido) nos valores de tensão, elongação e principalmente no módulo. De acordo com as micrografias feitas por MEV (figuras 5.7 e 5.9), as fibras apresentam uma maior molhabilidade pela matriz tipo $\mathrm{B}$, o que representa uma vantagem com relação à matriz tipo $\mathrm{A}$, considerando o desempenho mecânico.

Considerando este fato, resolveu-se realizar um novo estudo, mantendo-se fixo o teor de fibra de sisal e variando-se o teor de plastificante para cada um dos tipos de matrizes, para avaliar qual o comportamento em outras condições de estudo. Os teores de plastificante foram escolhidos abaixo e acima do ponto estudado anteriormente, ou seja, definiu-se $35,40,44$ e 48pcr de plastificante. $O$ teor de fibra de sisal foi fixado em $25 \mathrm{pcr}$, que foi o máximo teor estudado anteriormente. Este teor foi escolhido pela vantagem econômica em se ter um maior conteúdo de fibra, de menor custo comparado com os compostos. 


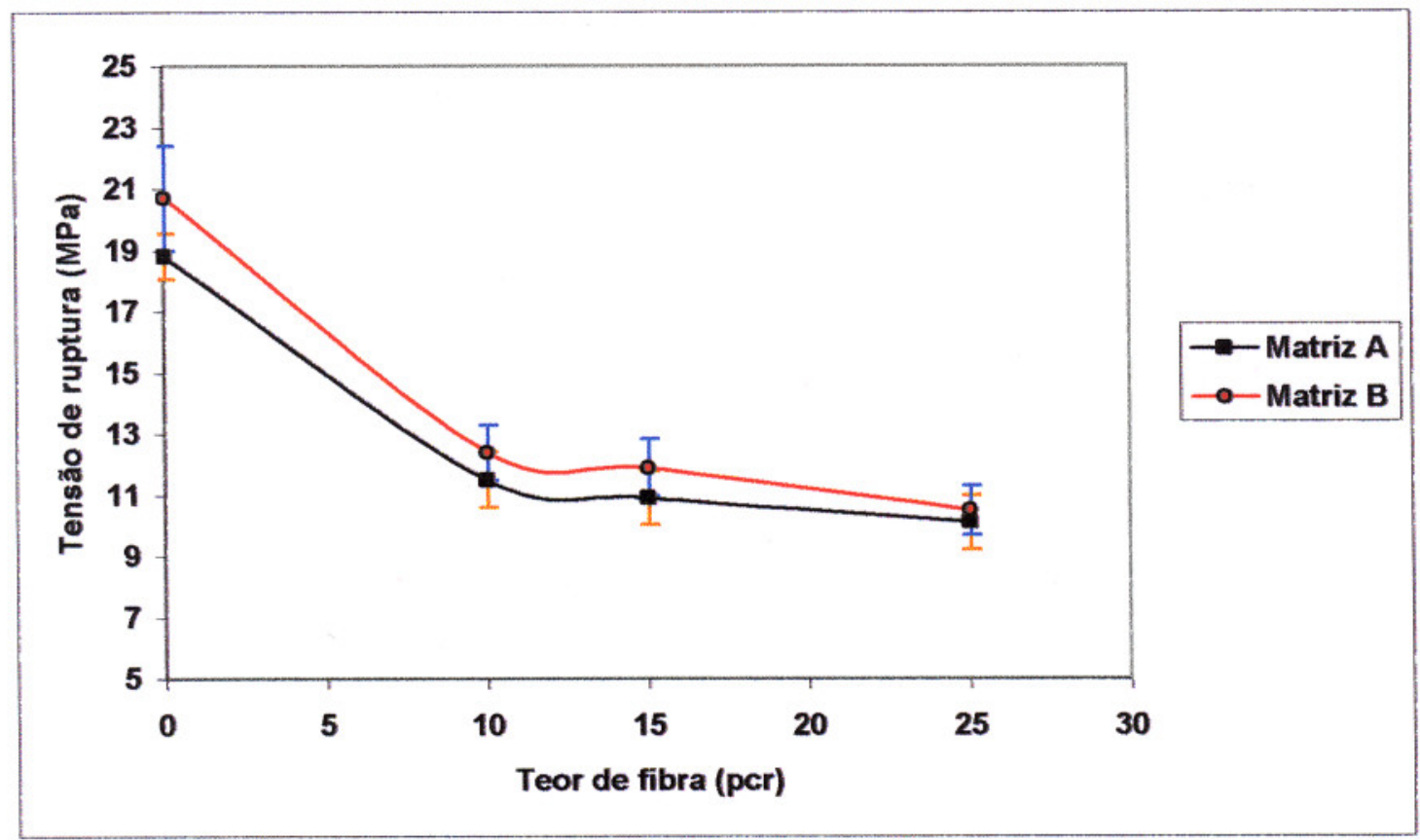

Figura 5.15 - Curvas de tensão de ruptura (MPa) versus teor de fibra de sisal nos compósitos tipo A (PVC + 40pcr de plastificante líquido) e tipo B (PVC + 40pcr de plastificante sólido Elvaloy ${ }^{\circledR}$ ). Os compósitos apresentam 10pcr, 15pcr e $25 \mathrm{pcr}$ de fibras de sisal (tamanho 6mm) comparado com a matriz pura.

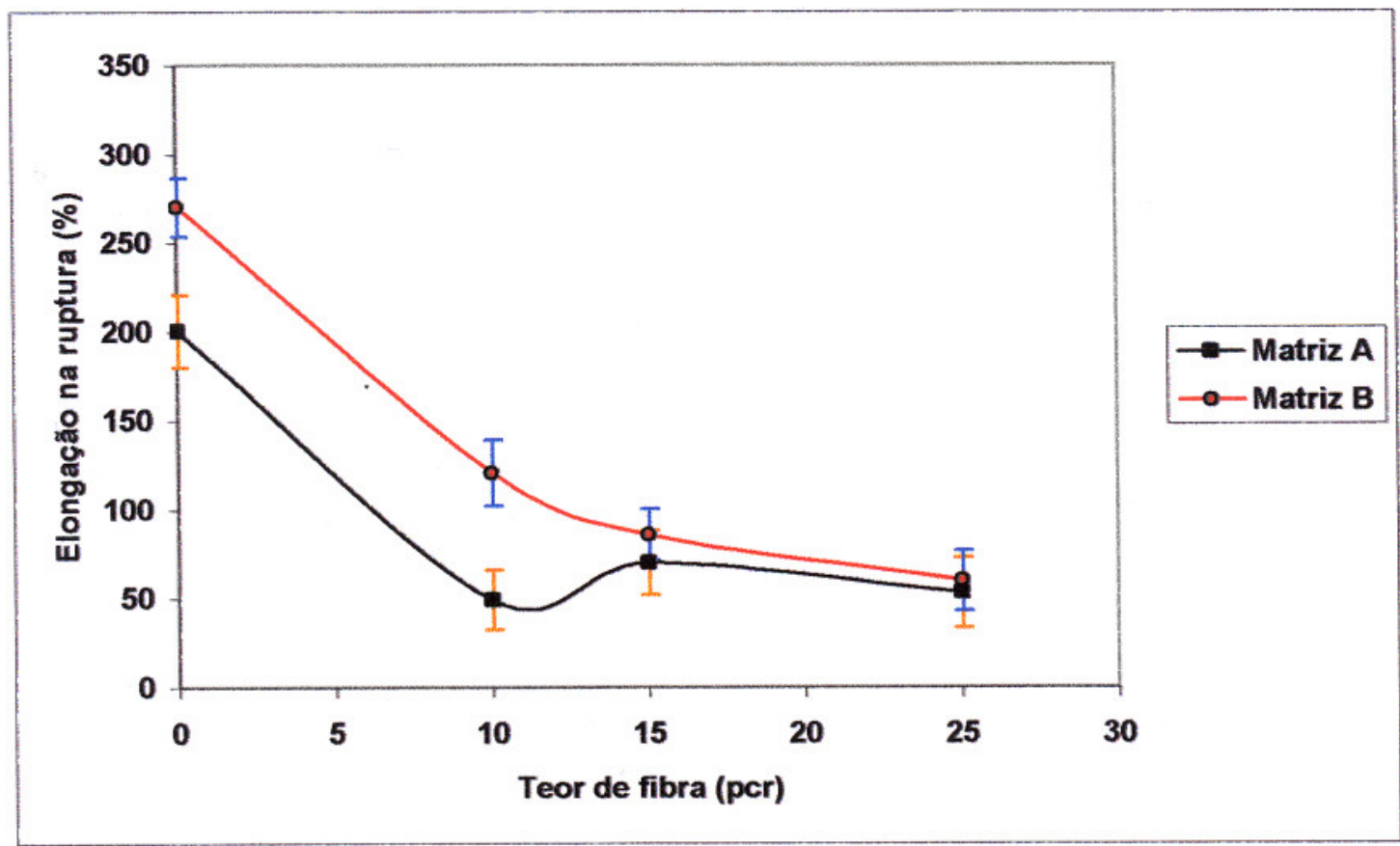

Figura 5.16 - Curvas de elongação na ruptura (\%) versus teor de fibra de sisal nos compósitos tipo A (PVC + 40pcr de plastificante líquido) e tipo B (PVC + 40pcr de plastificante sólido Elvaloy ${ }^{\circledR}$ ). Os compósitos apresentam 10pcr, 15 pcr e $25 \mathrm{pcr}$ de fibras de sisal (tamanho $6 \mathrm{~mm}$ ) comparado com a matriz pura. 


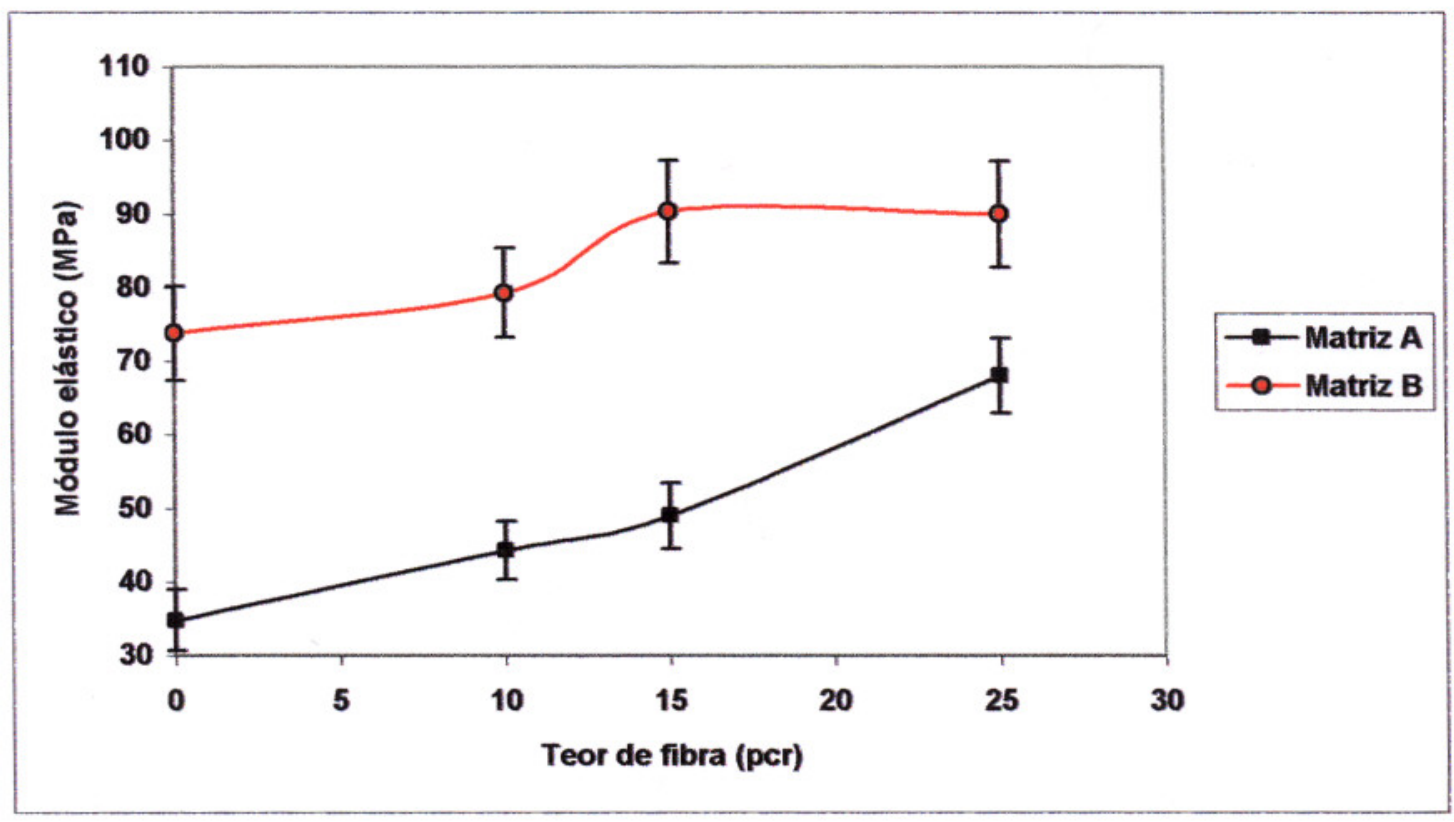

Figura 5.17 - Curvas de módulo elástico a $10 \%$ de elongação (MPa) versus teor de compósitos tipo A (PVC + 40pcr de plastificante líquido) e tipo B (PVC fibra de sisal nos +40 pcr de plastificante sólido Elvaloy $\left.{ }^{\circledR}\right)$. Os compósitos apresentam 10pcr, $15 \mathrm{pcr}$ e $25 \mathrm{pcr}$ de fibras de sisal (tamanho $6 \mathrm{~mm}$ ) comparado com a matriz pura.

\subsection{3 - Variação do teor de plastificante nas matrizes poliméricas}

Foram preparadas amostras das matrizes em estudo (tipos A e B) com diferentes teores de plastificante $(35,40,44$ e $48 \mathrm{pcr})$. Cada uma das amostras foi feita em duplicata, sendo que para uma delas acrescentou-se $25 \mathrm{pcr}$ de fibra de sisal (tamanho $6 \mathrm{~mm}$ ) e à outra não foi adicionado fibra. Deste modo, para cada teor de plastificante, temos amostras "com" e "sem" fibra.

Foram então realizados ensaios de tração para determinação da resistência à ruptura, elongação e módulo elástico (módulo a 10\% de elongação-região elástica), como nas situações anteriores. 
As figuras a seguir (Figuras 5.18, 5.19 e 5.20) mostram o comportamento relativo entre as matrizes tipo A e B, em função do teor de plastificante, com e sem a adição de 25 pcr de fibra de sisal (tamanho $6 \mathrm{~mm}$ ). Com relação à figura 5.18 , podese observar um comportamento que normalmente não é típico, ou seja, quando se aumenta o teor de plastificantes, normalmente existe uma tendência à queda dos valores de tensão de ruptura. Neste caso, este comportamento não foi observado, principalmente para a matriz tipo A. Vale lembrar que as condições de processo foram iguais para todos os teores e tipos de plastificante. Devido à alta viscosidade do plastificante líquido e à característica sólida da resina que atua como plastificante, possivelmente, uma otimização das condições de processo para cada formulação em estudo, poderia levar a um comportamento esperado para os valores de resistência à tração.

De acordo com os gráficos a seguir (figuras 5.18 e 5.19), observa-se que a adição de fibras de sisal na proporção de 25 pcr, provoca a redução dos valores de tensão e elongação das matrizes carregadas em relação às matrizes puras, para todos os teores de plastificante utilizados. Quando o teor de plastificante aumenta, ocorre um aumento da elongação para todas as matrizes em estudo (com e sem fibra).

A adição de fibras de sisal provoca um aumento do módulo elástico (figura 5.20) das matrizes carregadas com relação às matrizes puras. O aumento do teor de plastificante reduz os valores de módulo para todas as situações (matrizes "com" e "sem" adição de $25 \mathrm{pcr}$ de fibra de sisal). 


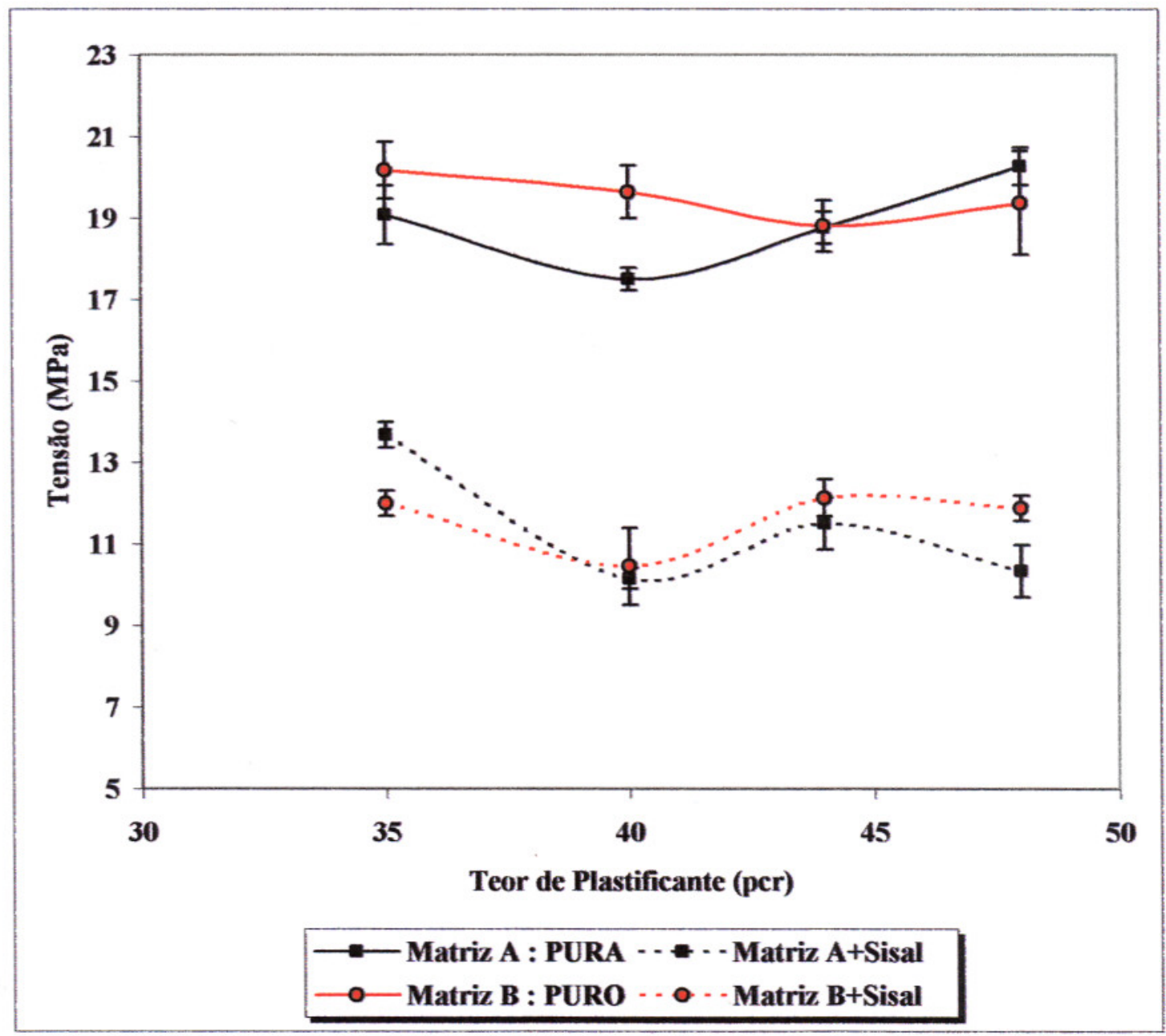

Figura 5.18 - Curvas de tensão de ruptura (MPa) versus teor de plastificante comparando cada uma das matrizes (tipos A e B), com e sem a adição de 25pcr de fibra de sisal (tamanho $6 \mathrm{~mm}$ ). 


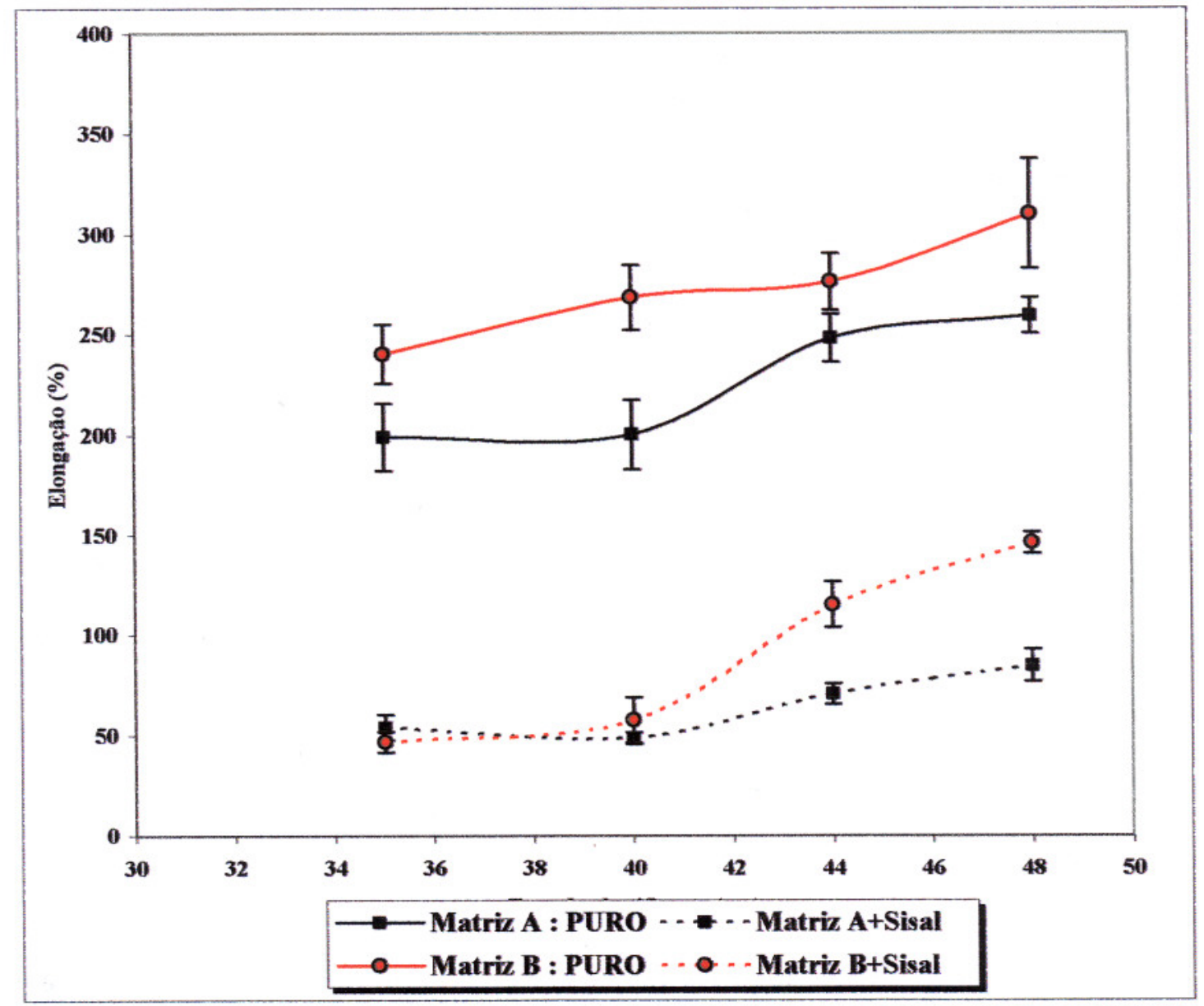

Figura 5.19 - Curvas de elongação na ruptura (\%) versus teor de plastificante comparando cada uma das matrizes (tipos A e B), "com" e "sem" a adição de 25 pcr de fibra de sisal (tamanho $6 \mathrm{~mm}$ ). 


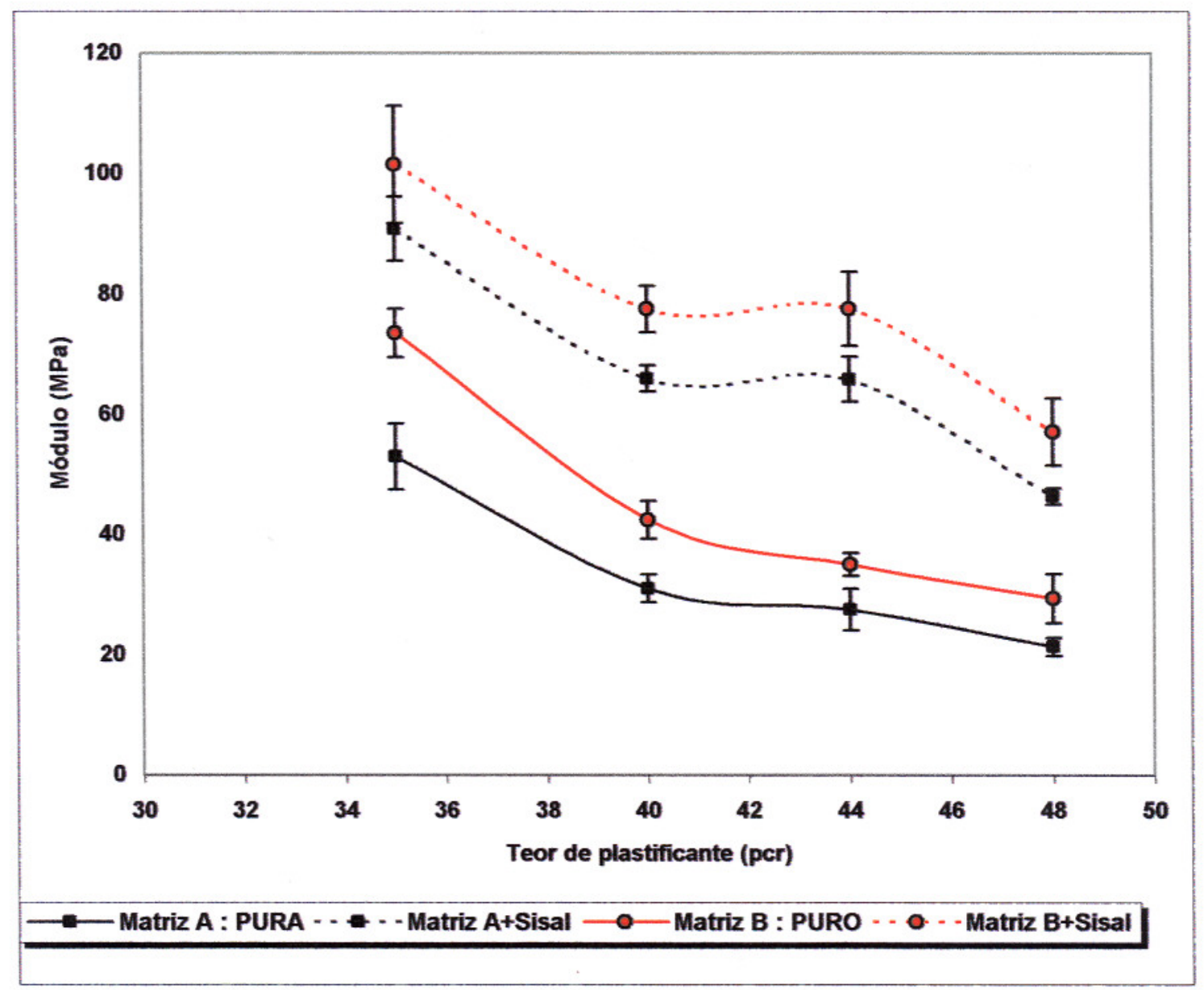

Figura 5.20 - Curvas de módulo elástico a 10\% de elongação (MPa) versus teor de plastificante comparando cada uma das matrizes (tipos A e B), "com" e "sem" a adição de 25 pcr de fibra de sisal (tamanho $6 \mathrm{~mm}$ ).

Os gráficos a seguir (figuras 5.21, 5.22 e 5.23), representam o comportamento dos compósitos (matrizes A e B carregadas com 25 pcr de plastificante) em função do teor de plastificante.

Considerando as curvas de tensão e elongação na ruptura (figuras $5.21 \mathrm{e}$ 5.22 ), pode-se notar que para o teor de plastificante de $35 \mathrm{pcr}$, a matriz do tipo A $(\mathrm{PVC}+$ plastificante líquido) tem valores maiores do que a matriz do tipo B (PVC + plastificante sólido Elvaloy ${ }^{\circledR}$ ). Para teores de plastificante acima de $38 \mathrm{pcr}$, ocorre uma inversão do fenômeno e a matriz tipo B passa a ter uma acentuada vantagem, 
principalmente quando se considera a elongação na ruptura (Figura 5.22). Com relação ao módulo elástico (Figura 5.23), a matriz tipo B apresenta valores superiores para todos os teores de plastificante. Estes resultados podem estar relacionados com as observações nos ensaios de MEV, onde se observou uma maior molhabilidade das fibras pela matriz B, o que promove uma maior interação fibra-matriz e, portanto, uma maior transferência da solicitação mecânica da matriz para a fibra, resultando em melhores propriedades mecânicas para o compósito.

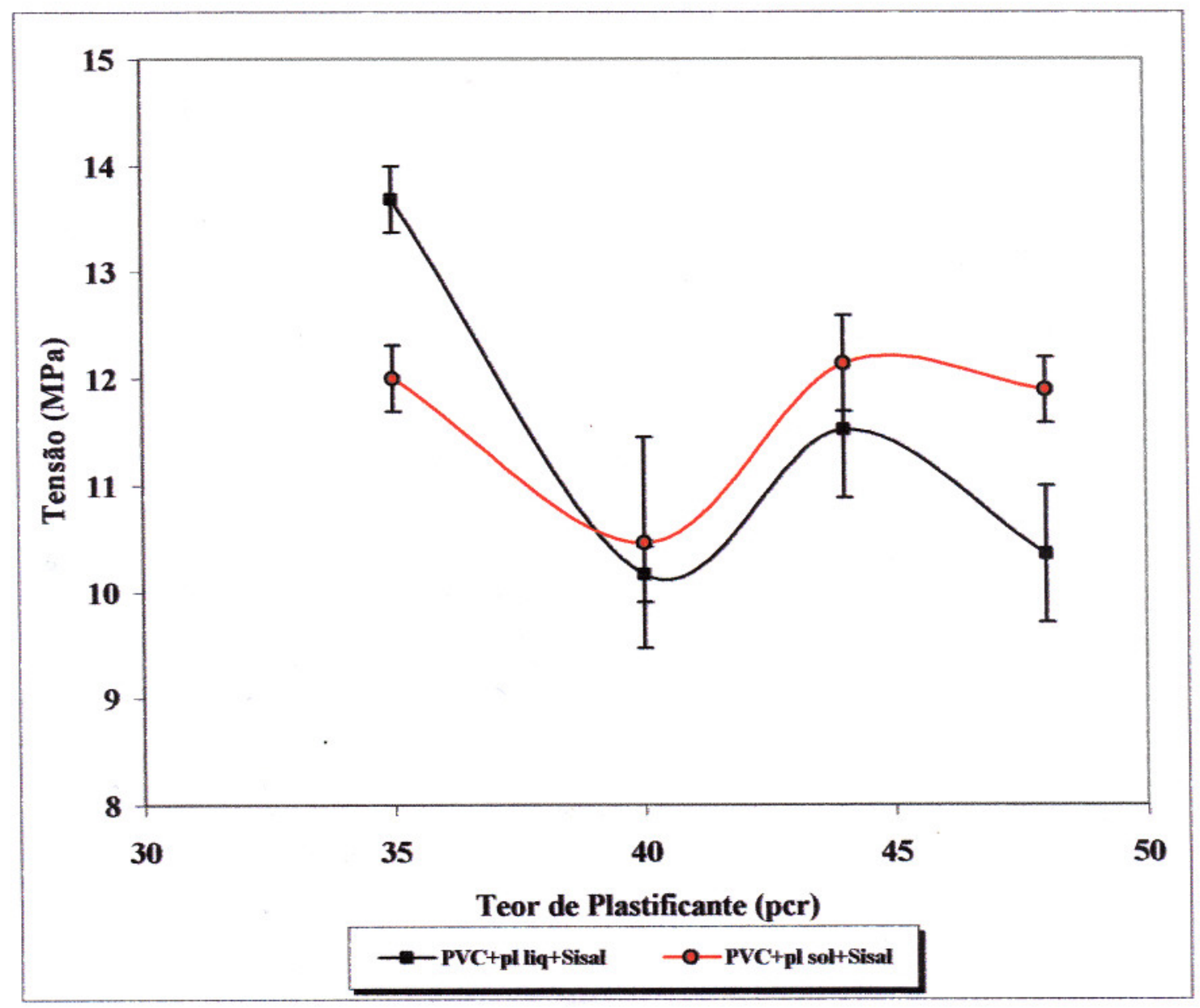

Figura 5.21 - Curvas de tensão de ruptura (MPa) versus teor de plastificante nos compósitos tipo A (PVC + plastificante líquido) e tipo B (PVC + plastificante sólido Elvaloy ${ }^{\circledR}$ ). Os compósitos apresentam 25 pcr de fibra de sisal (tamanho $6 \mathrm{~mm}$ ). 


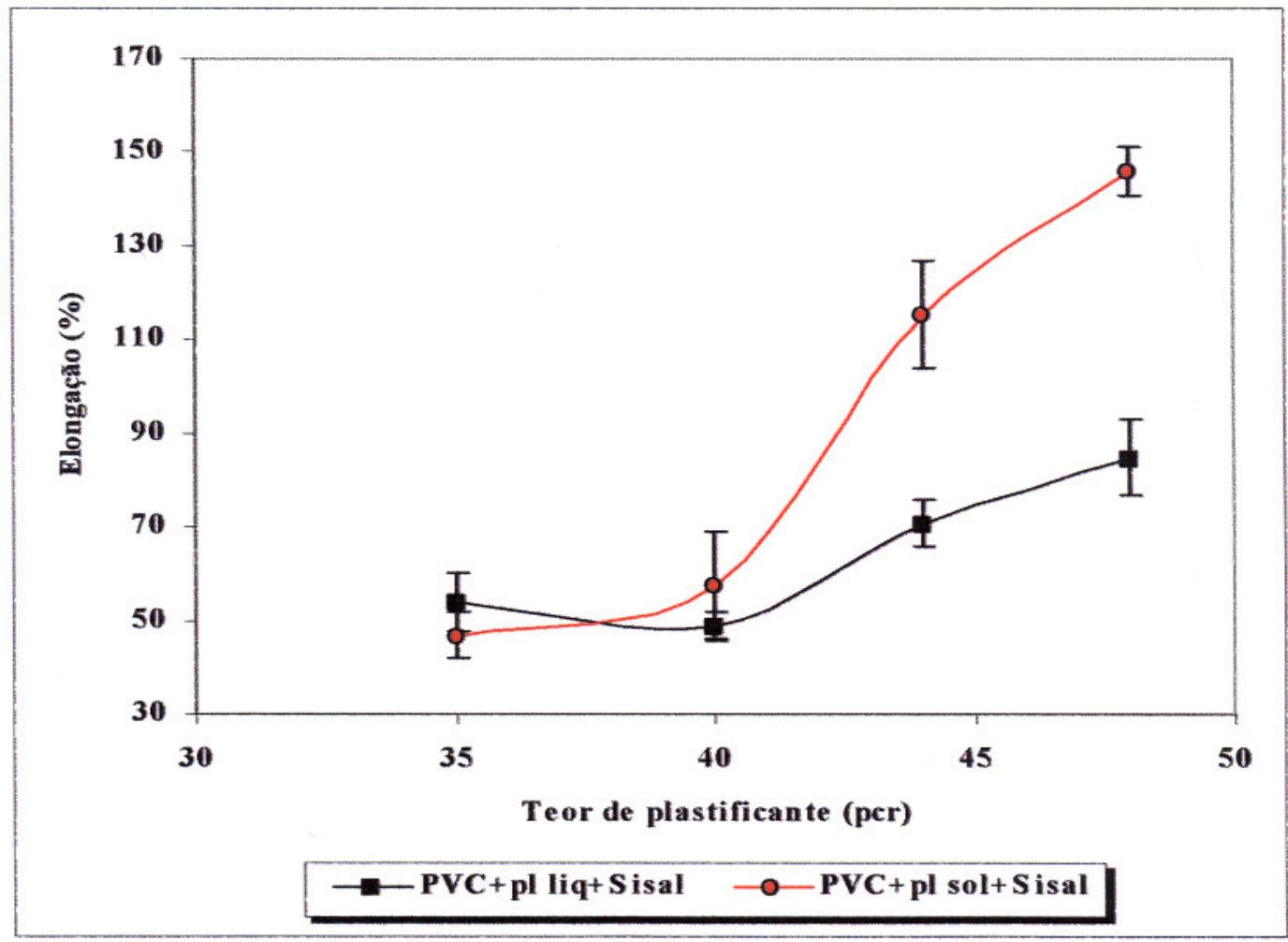

Figura 5.22 - Curvas de elongação na ruptura (\%) versus teor de plastificante nos compósitos tipo A (PVC + plastificante líquido) e tipo B (PVC + plastificante sólido Elvaloy ${ }^{\circledR}$ ). Os compósitos apresentam 25 pcr de fibra de sisal (tamanho $6 \mathrm{~mm}$ ).

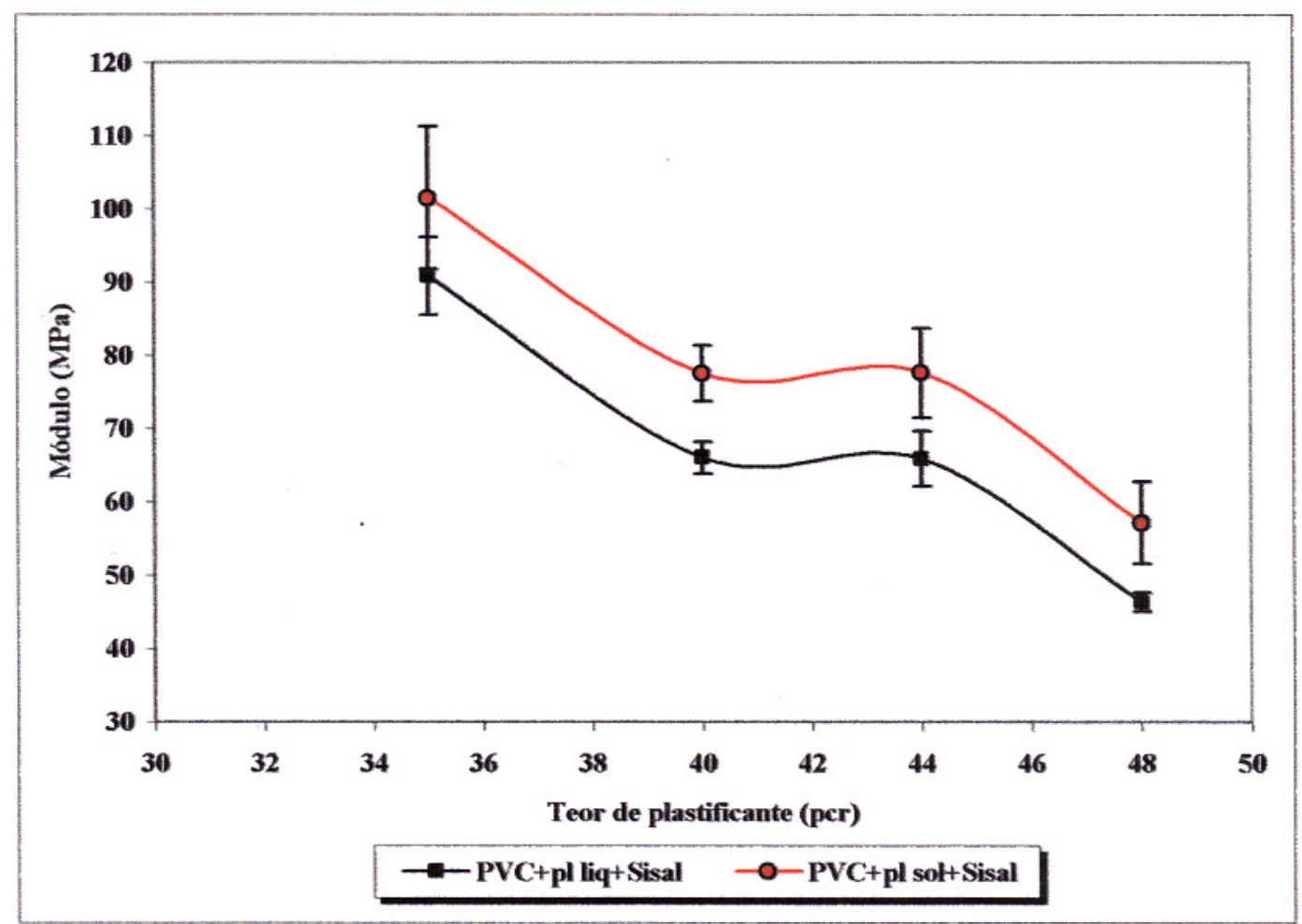

Figura 5.23 - Curvas de módulo a $10 \%$ de elongação (MPa) versus teor de plastificante nos compósitos tipo A (PVC + plastificante líquido) e tipo B (PVC + plastificante sólido Elvaloy ${ }^{\circledR}$ ). Compósitos têm $25 \mathrm{pcr}$ de sisal (tamanho $6 \mathrm{~mm}$ ). 
Os gráficos a seguir (Figuras 5.24 e 5.25), mostram a retenção dos valores de tensão de ruptura e elongação das matrizes (tipos A e B) carregadas com 25pcr de fibra de sisal, relativas às mesmas matrizes puras. Os valores de retenção (tanto para tensão quanto para elongação) foram calculados em termos percentuais para cada teor de plastificante. Pode-se verificar a vantagem da matriz tipo $\mathrm{B}$ com relação à matriz tipo A, para teores de plastificante acima de 43pcr para valores de tensão e, 42pcr para valores de elongação.

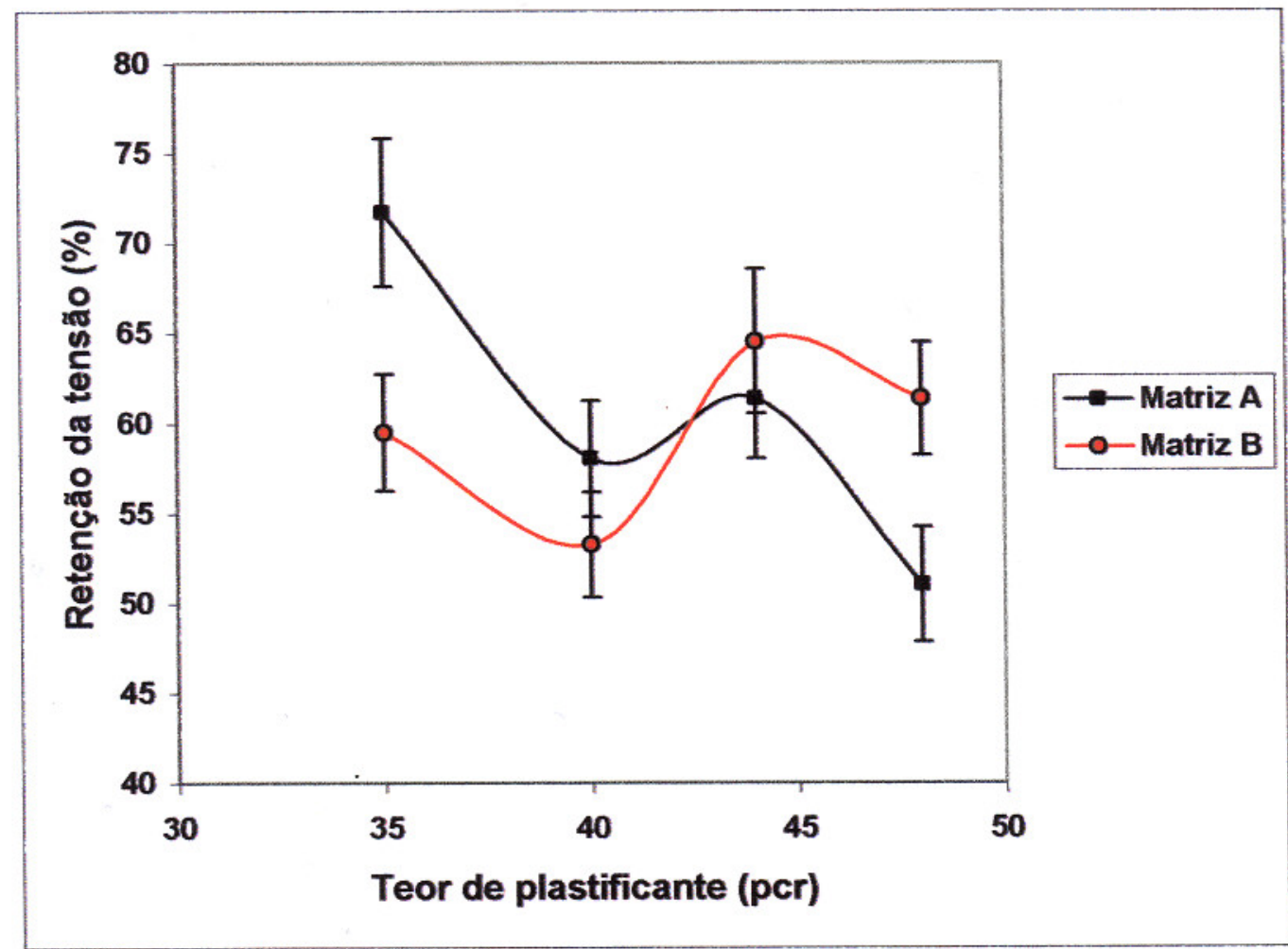

Figura 5.24- Retenção dos valores de tensão de ruptura das matrizes (tipos A e B) carregadas com 25 pcr de fibra de sisal (tamanho $6 \mathrm{~mm}$ ), com relação às matrizes puras em cada teor de plastificante estudado. 


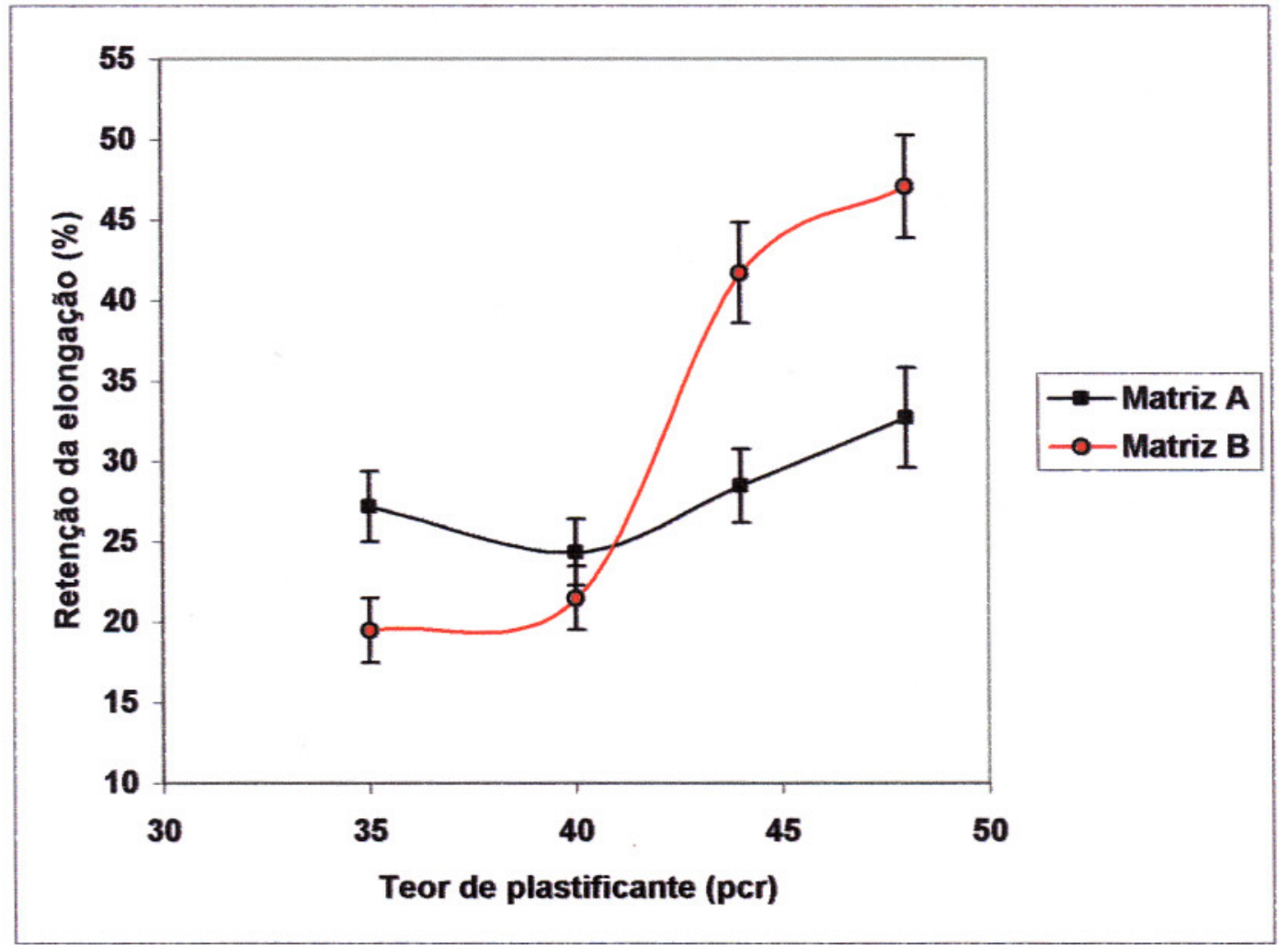

Figura 5.25 - Retenção dos valores de elongação na ruptura das matrizes (tipos A e B) carregadas com 25pcr de fibra de sisal (tamanho $6 \mathrm{~mm}$ ), com relação às matrizes puras em cada teor de plastificante estudado.

A seguir, são mostradas algumas curvas típicas dos comportamentos observados nos ensaios de tração para ambos os tipos de matrizes (tipos A e B), em função dos teores dos plastificantes estudados $(35,40,44$ e $48 \mathrm{pcr})$, para as matrizes carregadas com $25 \mathrm{pcr}$ de sisal $(6 \mathrm{~mm})$ e também, para estas mesmas matrizes sem fibra. 


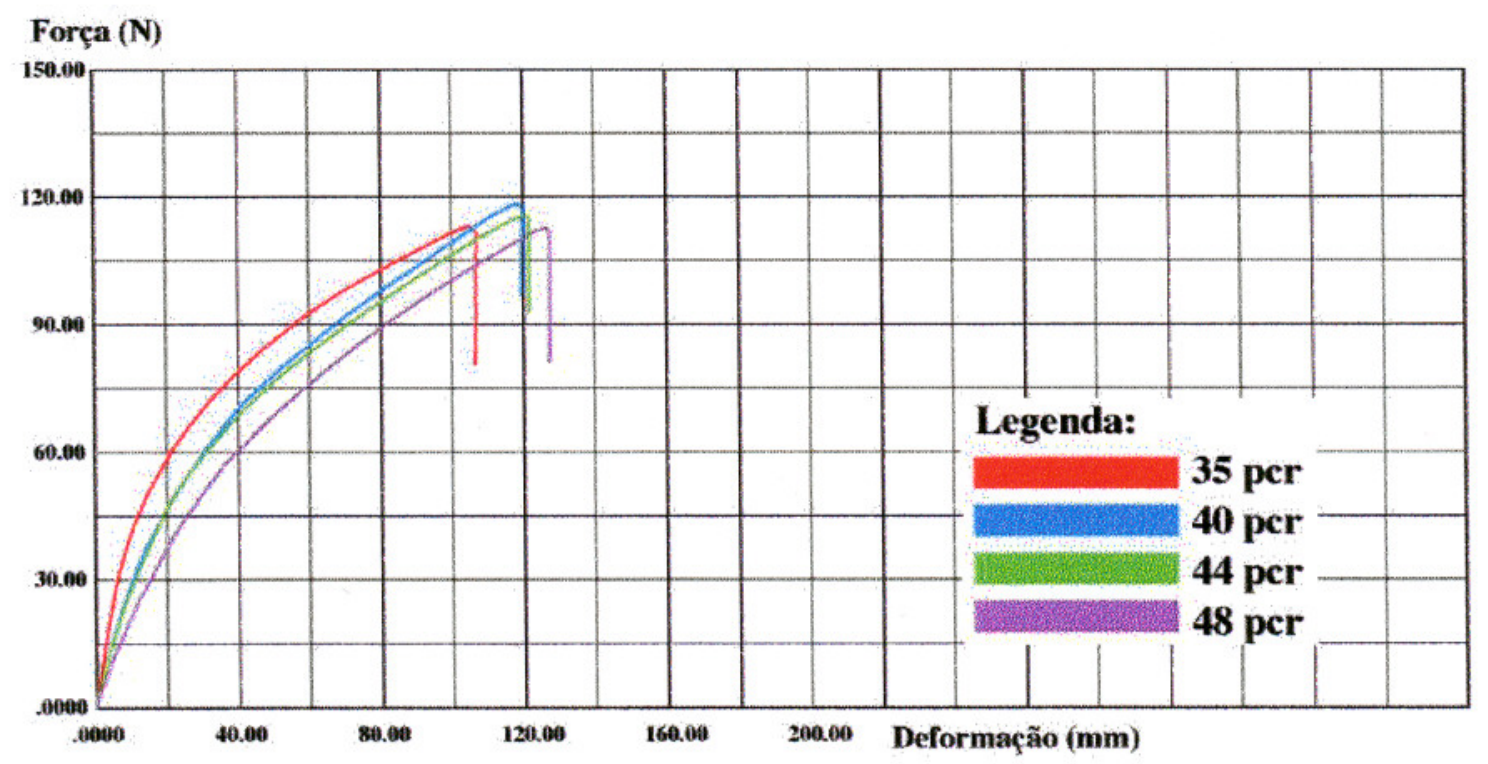

Figura 5.26 - Curvas obtidas nos ensaios de tração para matriz de PVC em função do teor de plastificante líquido (sem adição de fibras de sisal).

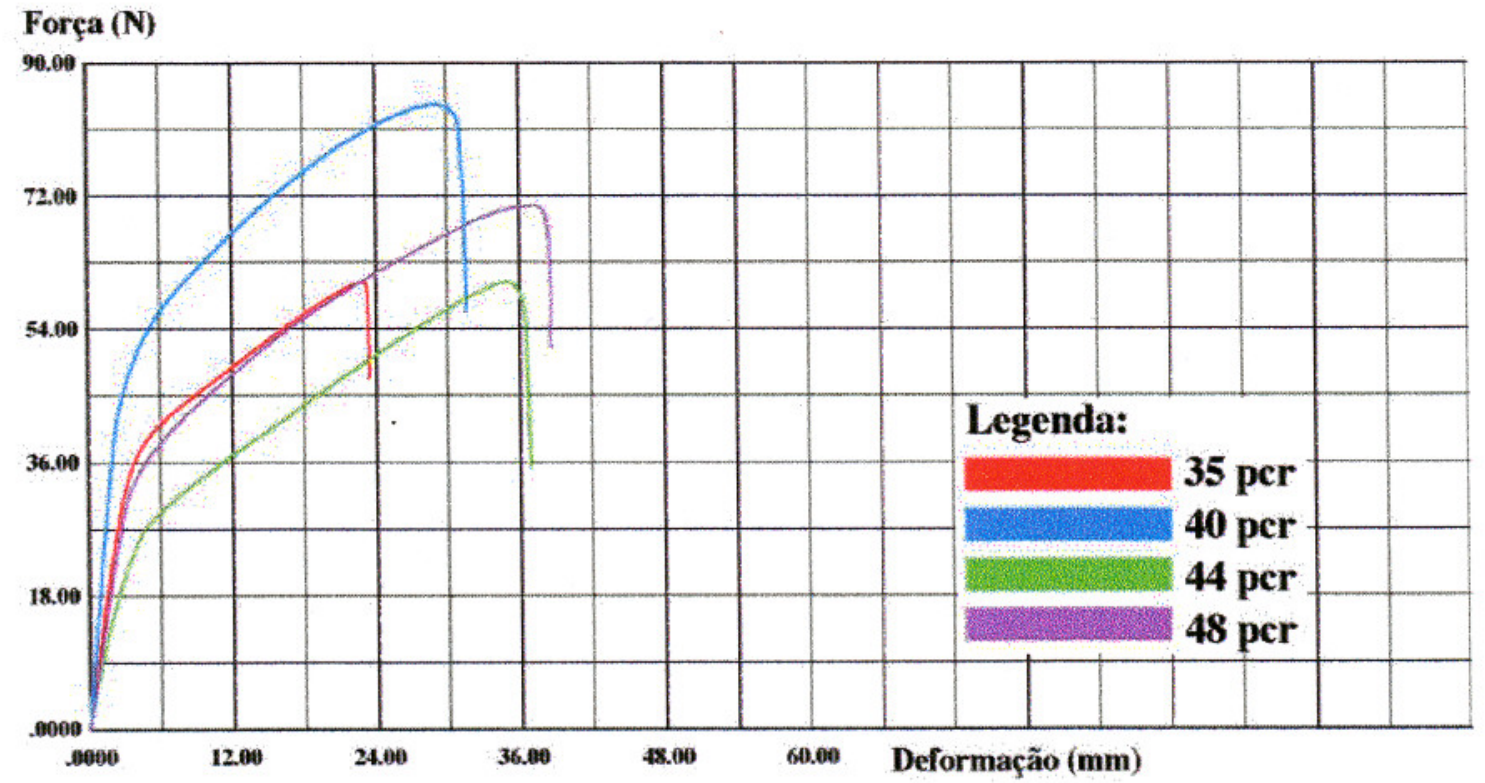

Figura 5.27 - Curvas obtidas nos ensaios de tração para matriz de PVC em função do teor de plastificante líquido, carregadas com 25 pcr de fibra de sisal (tamanho $6 \mathrm{~mm}$ ). 


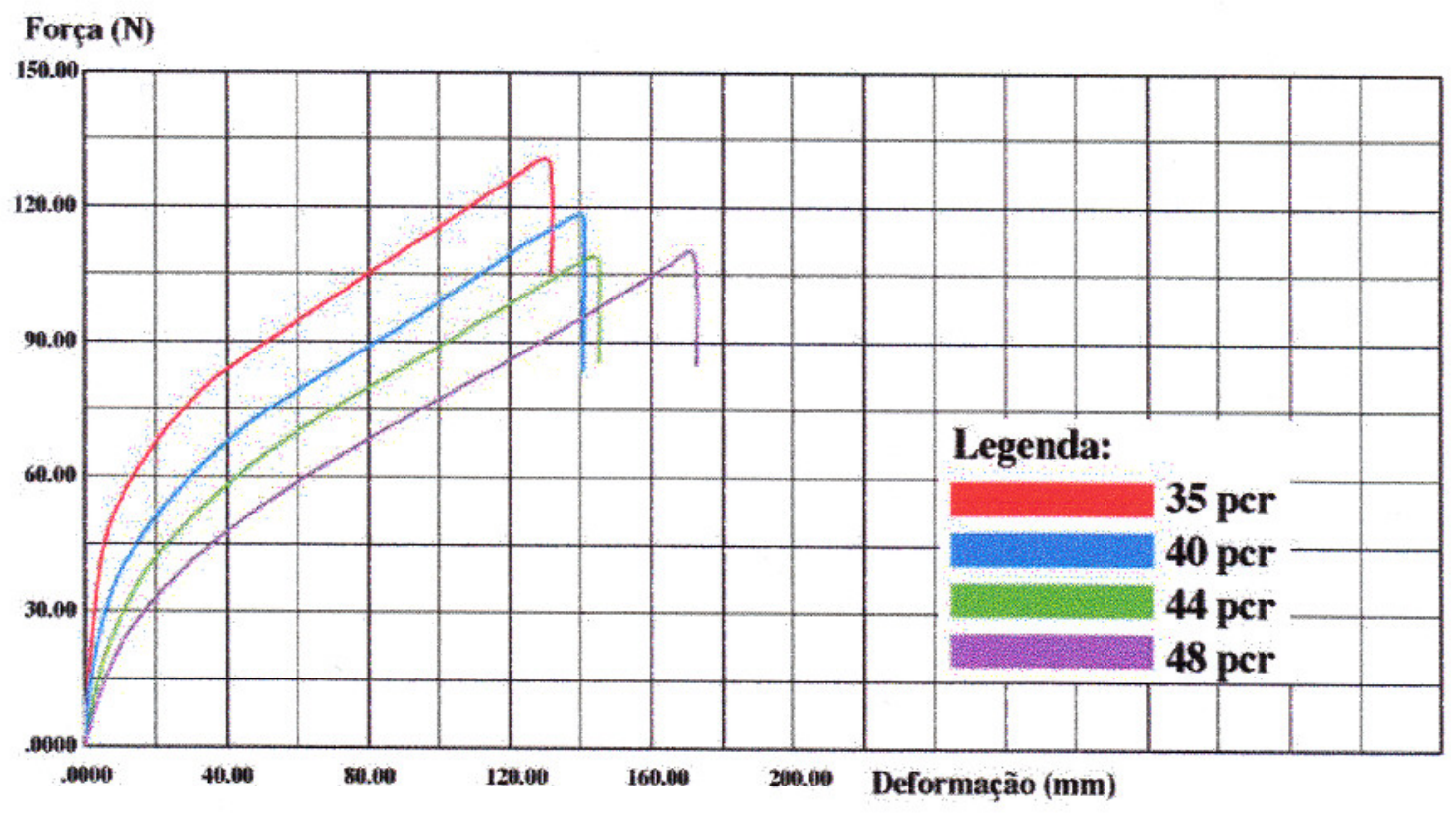

Figura 5.28 - Curvas obtidas nos ensaios de tração para matriz de PVC em função do teor de plastificante sólido $\left(\right.$ Elvaloy $^{\circledR}$ ), sem adição de fibras de sisal.

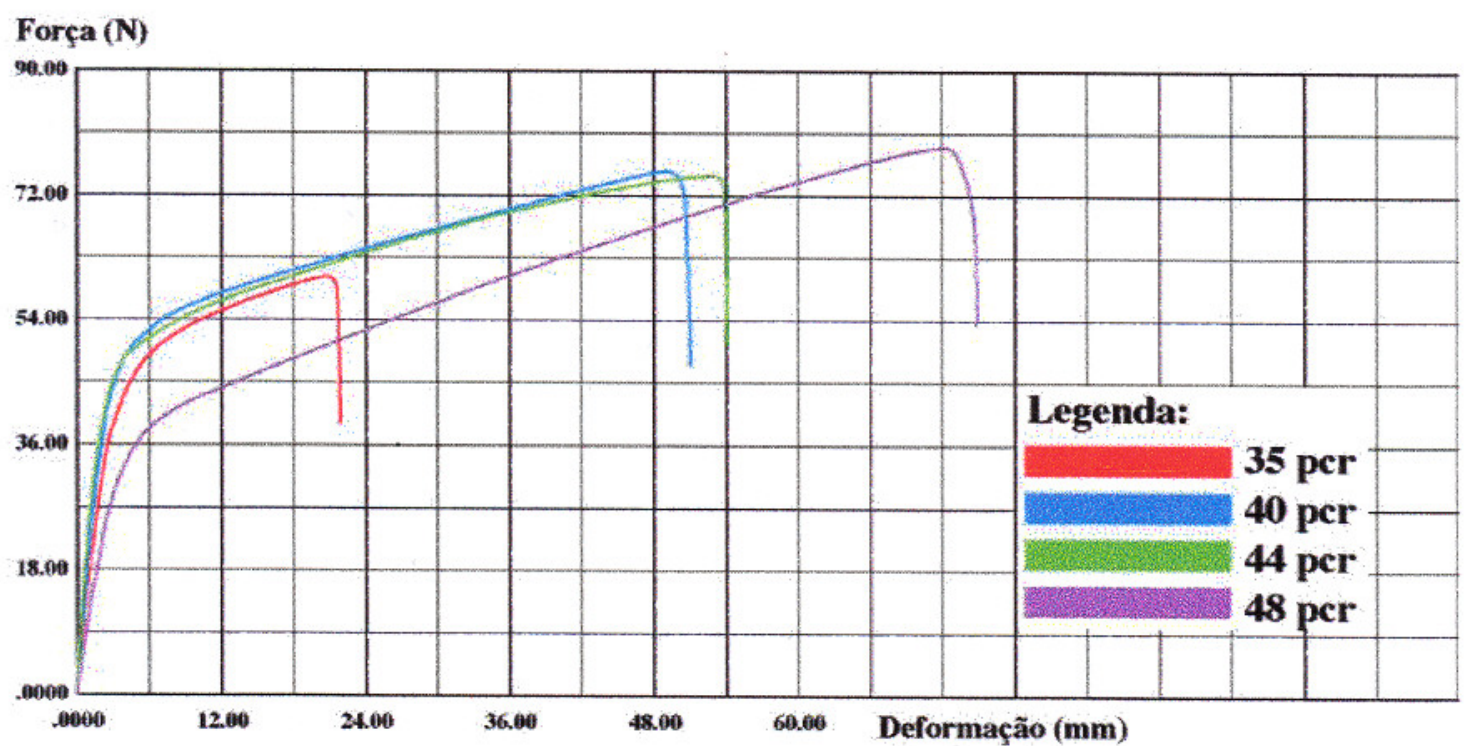

Figura 5.29 - Curvas obtidas nos ensaios de tração para matriz de PVC em função do teor de plastificante sólido $\left(\right.$ Elvaloy ${ }^{\circledR}$ ), carregadas com $25 \mathrm{pcr}$ de fibras de sisal (tamanho $6 \mathrm{~mm}$ ). 


\section{5 - Análises Térmicas}

Analisando-se as curvas obtidas nos ensaios de DSC, observa-se que o copolímero Elvaloy ${ }^{\circledR}$ (figura 5.30), apresenta um pico evidente que corresponde à temperatura de fusão cristalina $(\mathrm{Tm})$ do produto entre $55^{\circ} \mathrm{C}$ e $70^{\circ} \mathrm{C}$. Possivelmente a temperatura de transição vítrea (Tg) corresponde a uma mudança na linha base em torno de $-30^{\circ} \mathrm{C}$. Na literatura [53], estas temperaturas correspondem a $66^{\circ} \mathrm{C}$ para $\mathrm{Tm}$ $\mathrm{e}-32^{\circ} \mathrm{C}$ para $\mathrm{Tg}$

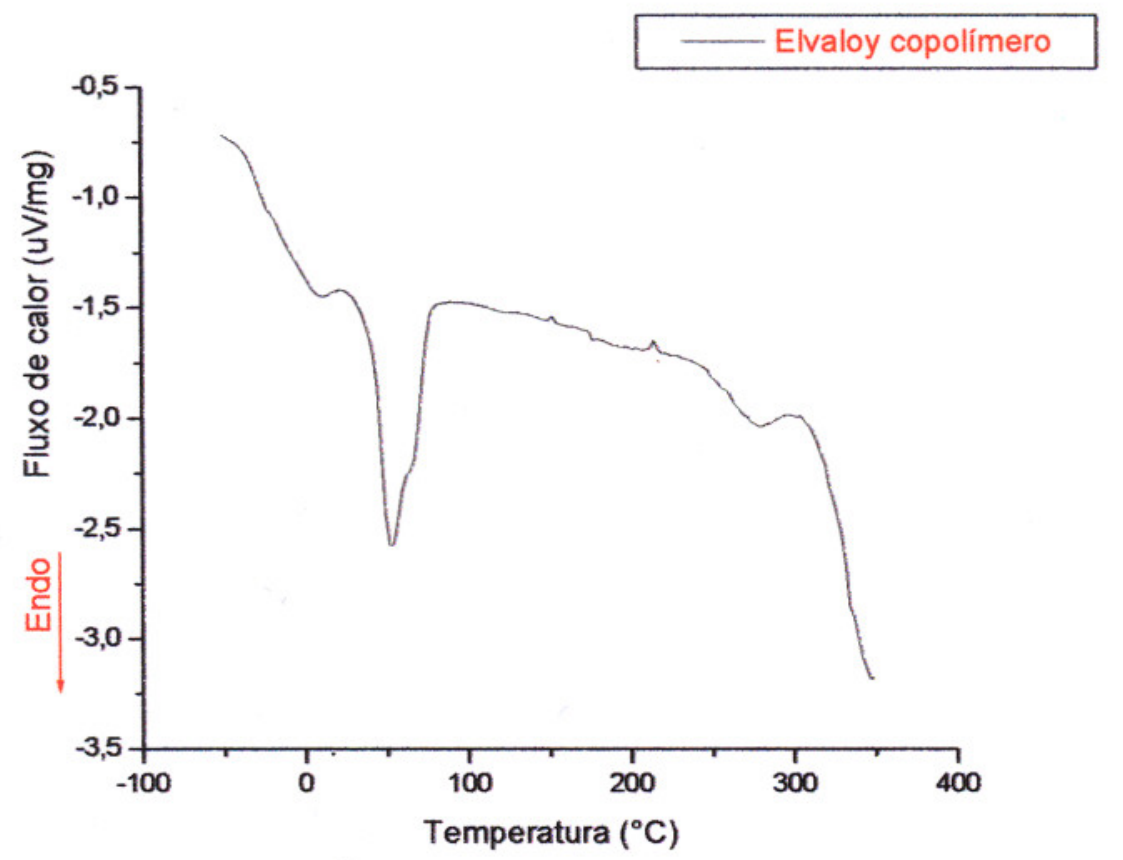

Figura 5.30 - Termograma DSC para o copolímero Elvaloy ${ }^{\circledR}$.

A seguir (figura 5.31), são mostrados termogramas DSC para matriz de PVC plastificado com 48 pcr de Elvaloy ${ }^{\circledR}$ (plastificante sólido), com a adição de $25 \mathrm{pcr}$ de fibras de sisal (compósito) e sem a adição das fibras (matriz pura). A curva para 
Elvaloy ${ }^{\circledR}$ puro foi plotada junto para comparação. A resina de PVC pura não foi analisada porque sem a adição de estabilizante térmico, ocorrerá um processo de degradação excessivo da resina, produzindo uma curva de pouco interesse para o estudo. A mesma consideração vale para o ensaio de TGA.

Observa-se que a presença do plastificante sólido Elvaloy ${ }^{\circledR}$ é responsável por picos endotérmicos em torno da temperatura de $50^{\circ} \mathrm{C}$, que sugere um percentual de cristalização, tanto para o compósito quanto para a matriz pura.

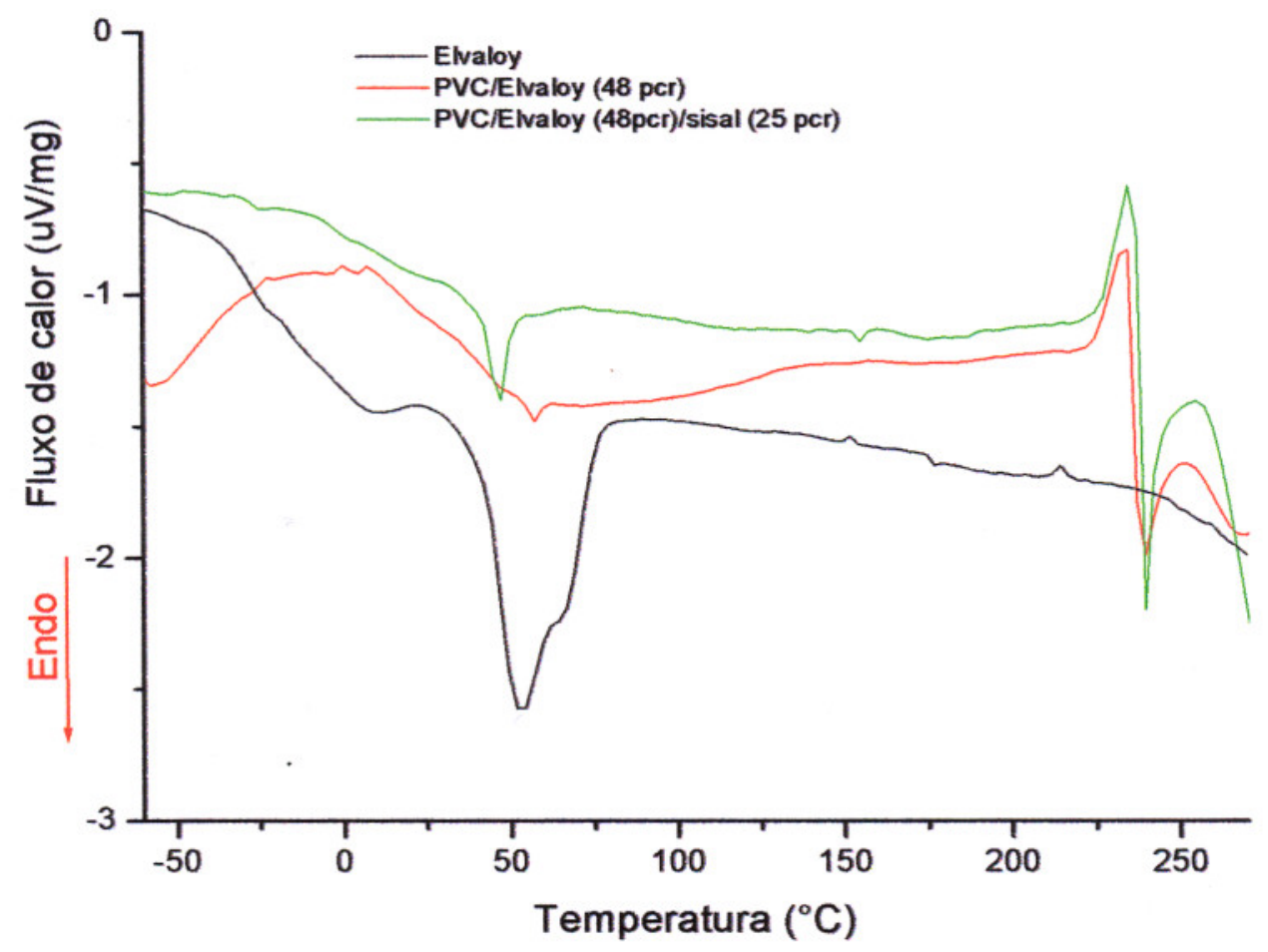

Figura 5.31 - Curvas DSC para matriz PVC plastificada com 48pcr de plastificante sólido Elvaloy ${ }^{\circledR}$ e para a mesma matriz carregada com 25 pcr de fibra de sisal. A curva para Elvaloy ${ }^{\circledR}$ puro foi colocada junto para comparação.

Na figura 5.32 foi feita uma comparação entre as duas matrizes em estudo (tipos A e B), com teor de plastificante de 48pcr carregadas com 25pcr de fibra de 
sisal. Observa-se que a matriz do tipo A (PVC + plastificante líquido), não apresenta o pico de fusão cristalina em torno de $50^{\circ} \mathrm{C}$ mostrado pela matriz do tipo $\mathrm{B}(\mathrm{PVC}+$ plastificante sólido). Este pico pode estar relacionado com uma possível separação de fase do plastificante sólido durante o processo de resfriamento. A matriz do tipo A, apresenta um forte desvio da linha base em uma faixa de temperatura que vai desde $25^{\circ} \mathrm{C}$ até $75^{\circ} \mathrm{C}$. Este desvio pode estar relacionado com desenvolvimento de cristalinidade no PVC plastificado, de acordo com a literatura [48]. Observa-se que acima de $250^{\circ} \mathrm{C}$ ocorre um processo endotérmico que provavelmente está relacionado com a volatilização dos plastificantes e outros aditivos comuns para ambas as matrizes poliméricas.

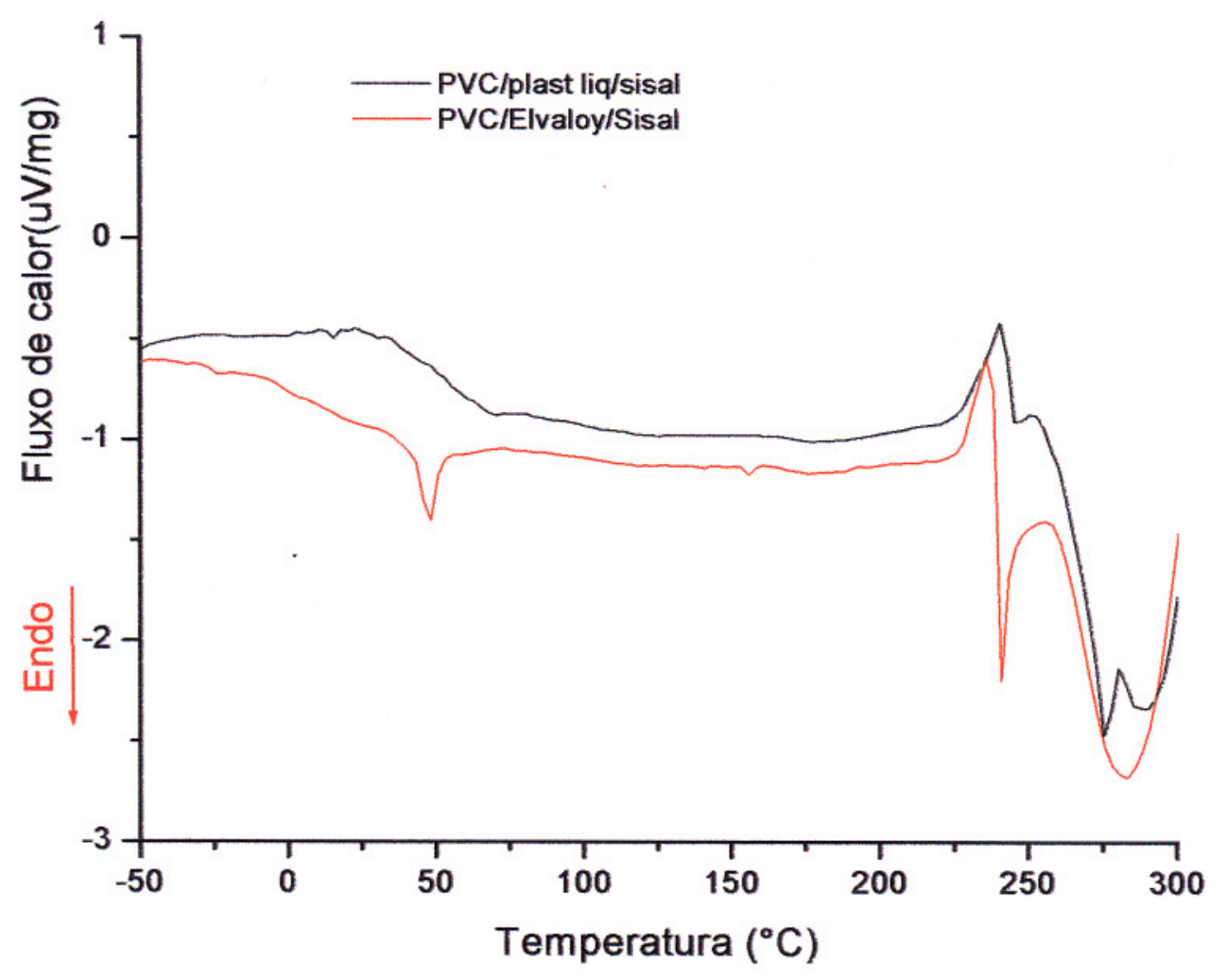

Figura 5.32 - Curvas DSC comparando matrizes do tipo A (PVC $+48 \mathrm{pcr}$ de Plastificante líquido) e do tipo B (PVC + 48pcr de plastificante sólido), carregadas com $25 \mathrm{pcr}$ de fibras de sisal. 
Comparando-se as curvas de TGA para as matrizes do tipo $\mathrm{A}(\mathrm{PVC}+$ plastificante líquido) e tipo $\mathrm{B}\left(\mathrm{PVC}+\right.$ plastificante sólido Elvaloy $\left.{ }^{\circledR}\right)$ para teores de plastificante de $35 \mathrm{pcr}$ e $48 \mathrm{pcr}$ (figura 5.33), observa-se que a substituição do plastificante líquido pelo plastificante sólido nas proporções estudadas, não alterou estabilidade térmica dos materiais nas condições do ensaio, até a temperatura de aproximadamente $250^{\circ} \mathrm{C}$. A partir de $300^{\circ} \mathrm{C}$, nota-se que ocorre uma perda de massa mais acentuada para a matriz tipo A, que contém plastificante líquido. Este comportamento pode ser explicado quando se observa o comportamento do plastificante sólido Elvaloy ${ }^{\circledR}$, que inicia a perda de massa em temperaturas próximas a $300^{\circ} \mathrm{C}$. Por consequiência, compostos formulados com Elvaloy ${ }^{\circledR}$, apresentam uma menor perda de massa acima de $300^{\circ} \mathrm{C}$ até $430^{\circ} \mathrm{C}$, quando comparados com compostos formulados com plastificante líquido. Para temperaturas acima de $450^{\circ} \mathrm{C}$, os fenômenos que ocorrem foram considerados pouco importantes, pois, envolvem condições muito distantes da situação real de aplicação para estes tipos de compostos. 


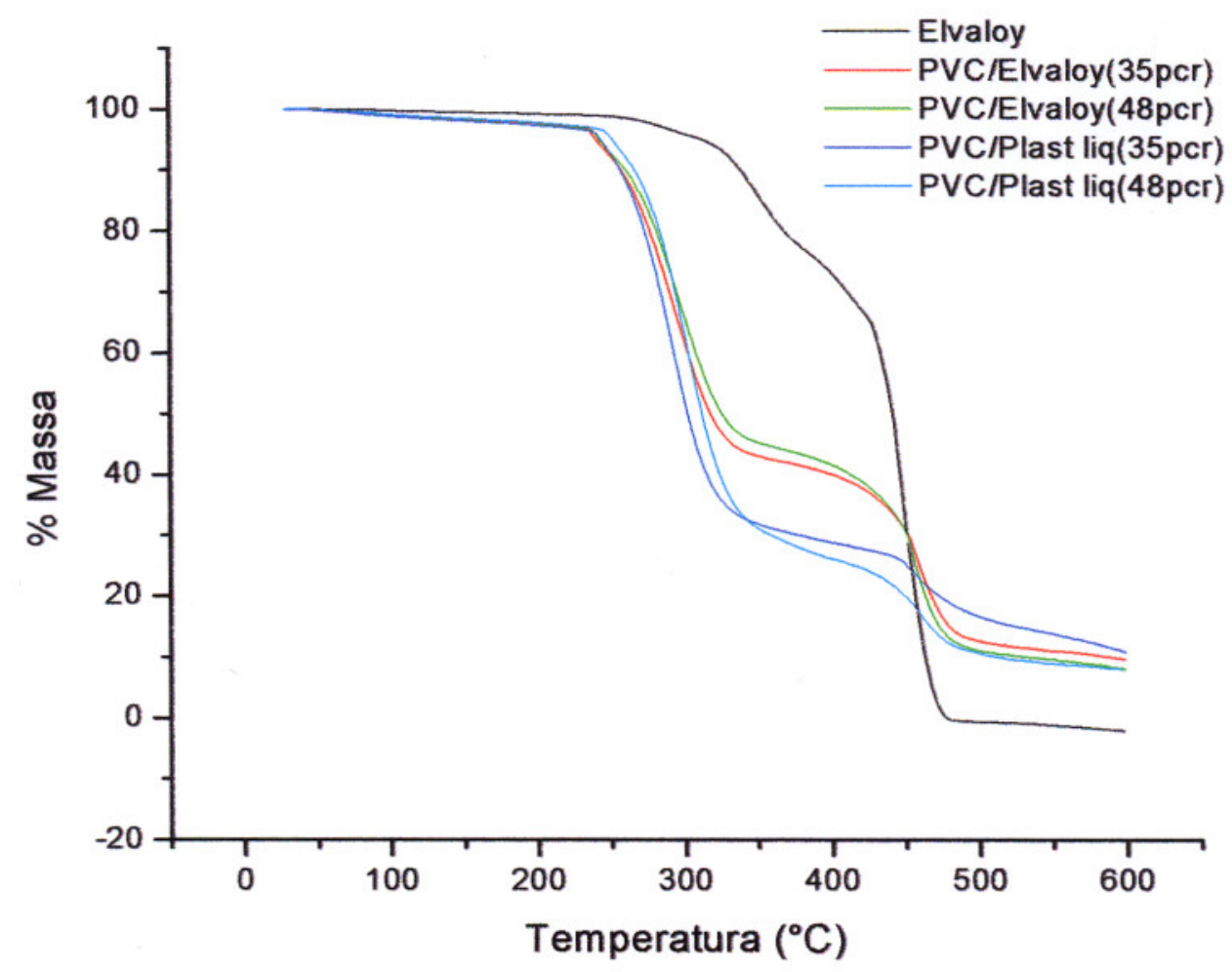

Figura 5.33 - Curvas de TGA para matrizes tipos A e B com 35 e 48pcr de plastificante. Curva para Elvaloy ${ }^{\circledR}$ foi plotada para comparação.

Considerando-se as matrizes tipos A e B (com teores de plastificante líquido de 35 e 48pcr), com e sem a adição de fibras de sisal (figuras 5.34 e 5.35), nota-se que a adição das fibras na proporção de 25 pcr não alterou significativamente o comportamento das curvas de TGA, para ambos os materiais nas condições do ensaio. Isto provavelmente se deve ao fato das fibras de sisal não introduzirem um processo de degradação adicional pela interação com as matrizes poliméricas em estudo e, também, devido à perda de massa do sisal durante o aquecimento, que ocorre entre $200^{\circ} \mathrm{C}$ e $400^{\circ} \mathrm{C}$ [58], coincidindo com a perda de massa dos plastificantes usados. 


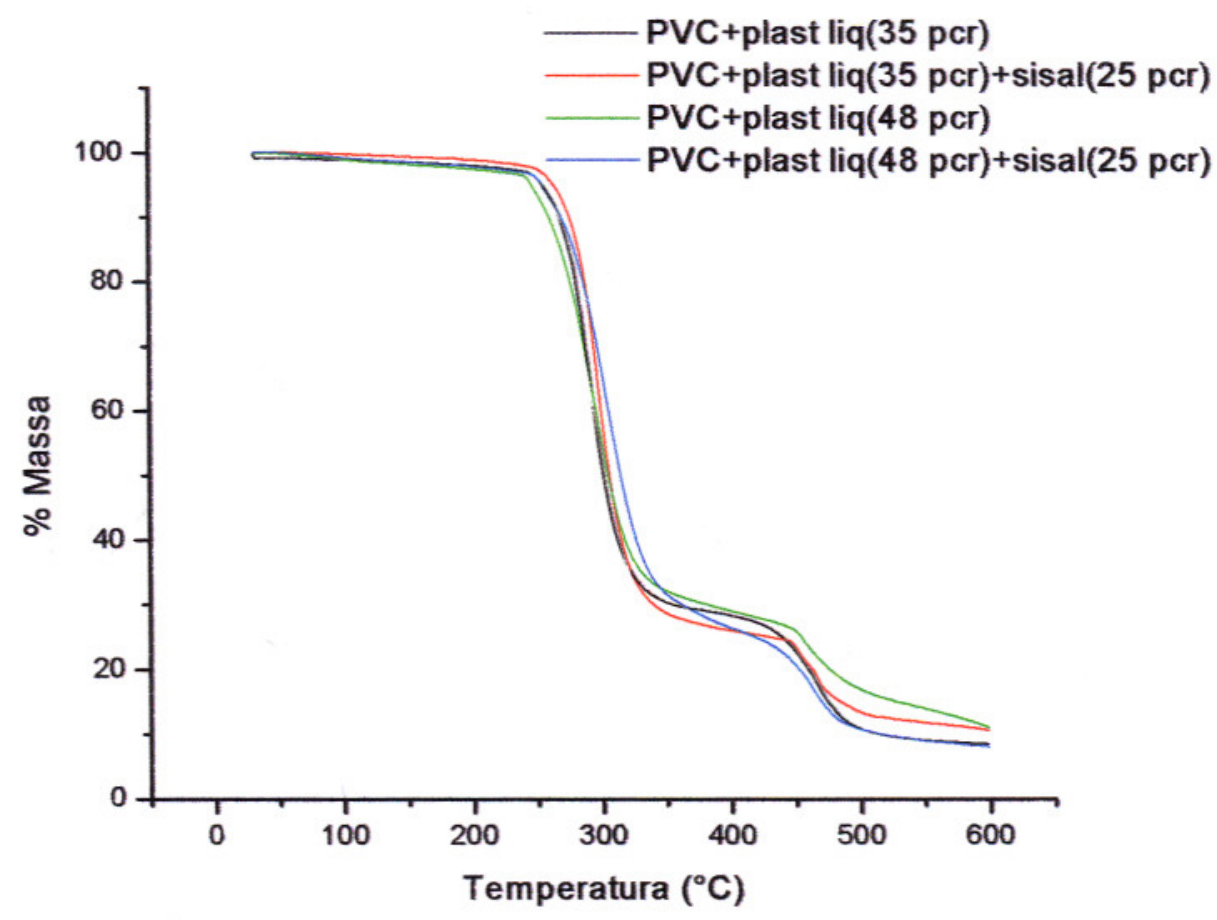

Figura 5.34 - Curvas de TGA para matriz tipo A com 35 e 48pcr de plastificante líquido, com e sem a adição de fibras de sisal.

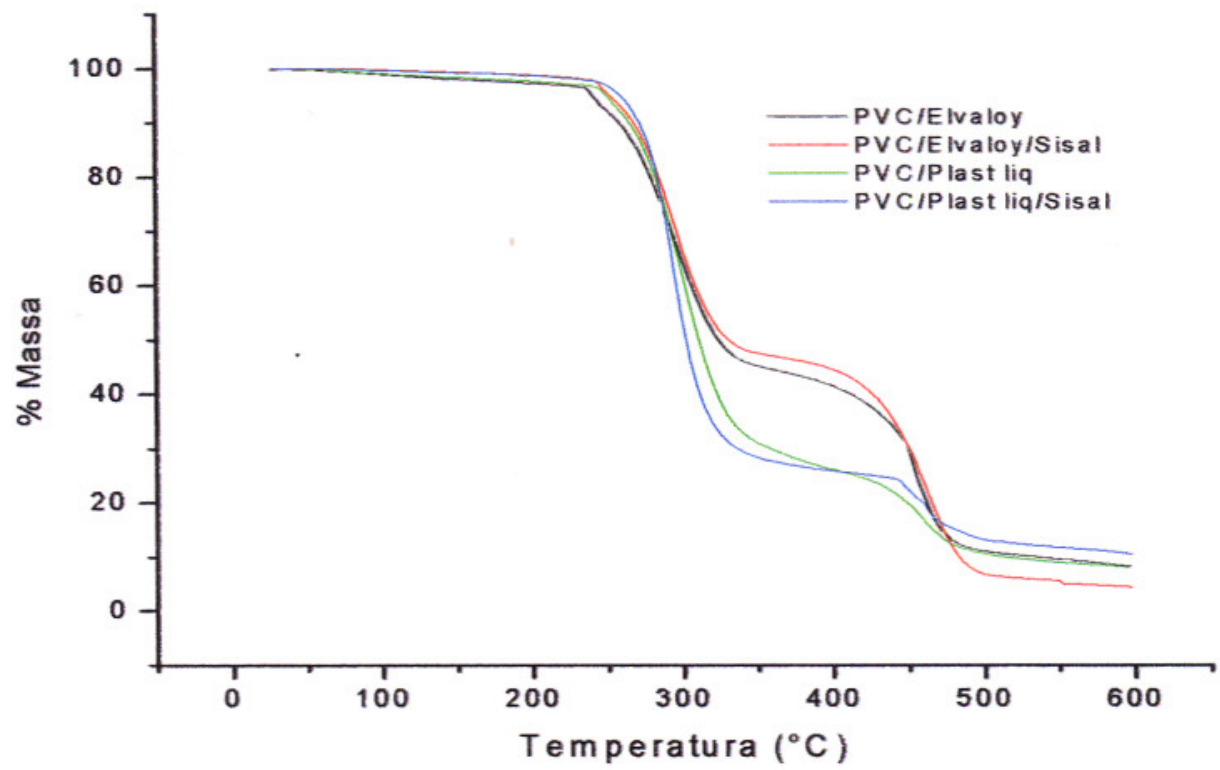

Figura 5.35 - Curvas de TGA para matriz tipo B com 35 e 48pcr de plastificante sólido, com e sem a adição de fibras de sisal. Curva para o Elvaloy ${ }^{\circledR}$ foi plotada para comparação. 


\section{6- CONCLUSÕES E OBSERVAÇÕES}

6.1- Nas condições estudadas, a substituição de um plastificante líquido por um plastificante sólido (copolímero Etileno / Acetato de vinila / Monóxido de carbono Elvaloy ${ }^{\circledR}$ ) em resina de poli (cloreto de vinila) (PVC), mostrou-se perfeitamente viável. Observou-se uma boa compatibilidade entre a resina de PVC e o copolímero, sendo de fácil processabilidade durante a calandragem. Os resultados dos ensaios mecânicos comparando os dois tipos de matrizes formadas comprovam esta afirmação. Para todos os teores de plastificante, em praticamente todas as condições estudadas, observou-se melhoria nos resultados de tensão, elongação e módulo quando se usa o plastificante sólido em substituição ao plastificante líquido.

6.2- Micrografias obtidas por microscopia eletrônica de varredura (MEV) para os compósitos criofraturados, mostraram que as fibras de sisal têm uma tendência à maior molhabilidade pelas matrizes compostas por PVC/Elvaloy ${ }^{\circledR}$ (plastificante sólido), quando comparadas com matrizes compostas por PVC/Plastificante líquido.

6.3- A maior tendência à molhabilidade das fibras de sisal pela matriz PVC/Plastificante sólido (PVC/Elvaloy ${ }^{\circledR}$ ), pode estar relacionada com os maiores valores de retenção da tensão e da elongação de ruptura para teores de plastificante 
acima de 42pcr (compósitos com 25pcr de sisal), quando comparados com a matriz PVC/plastificante líquido. Acima deste teor de plastificação, observou-se uma expressiva melhoria nos resultados de retenção dos valores de tensão e elongação dos compósitos formulados com o plastificante sólido.

6.4- Para ambos os tipos de matrizes poliméricas estudadas, o tamanho ideal de fibra foi de $6 \mathrm{~mm}$, quando se considera a tensão de ruptura. Este comportamento foi mais evidente para a matriz PVC/Plastificante líquido. Para as outras propriedades estudadas (elongação e módulo elástico), a influência dos tamanhos de fibra estudados foi pouco significativa e ambas as matrizes apresentaram comportamento similar.

6.5- Para ambas as matrizes estudadas, independente dos teores dos plastificantes avaliados, a adição de fibras de sisal (em todos os teores e tamanhos estudados), sempre aumenta o módulo elástico dos compósitos em relação às matrizes puras.

6.6- Ensaios comparativos de DSC mostraram que compósitos formulados a partir de matrizes PVC/ Elvaloy ${ }^{\circledR}$ apresentam um determinado grau de cristalinidade, o que não foi observado com a mesma evidência para matrizes PVC/Plastificante líquido. Este grau de cristalinidade está relacionado com a presença do Elvaloy ${ }^{\circledR}$ na formulação.

6.7- Ensaios comparativos de TGA mostraram que a matriz PVC/Elvaloy ${ }^{\circledR}$ tem menor perda de massa em temperaturas acima de $300^{\circ} \mathrm{C}$ até $430^{\circ} \mathrm{C}$, comparada com a 
matriz PVC/plastificante líquido. Para temperaturas inferiores, o comportamento é similar. Nas condições de ensaio, a presença das fibras de sisal não interferiram neste comportamento. 


\section{7- REFERÊNCIAS BIBLIOGRÁFICAS}

[1] KURUVILLA, J.; THOMAS, S. Effects of ageing on the physical and mechanical properties of sisal-fiber-reinforced polyethylene composites, Composites Science and Technology, v. 53, p. 99-110, 1995.

[2] JOSEPH K.; VARGHESE S.; KALAPRASAD G.; THOMAS, S.; PRASANNAKUMAR, L.; KOSHY, P. et al. Influence of interfacial adhesion on the mechanical properties and fracture behavior of short sisal fiber reinforced polymer composites. European Polymer Journal, v.32 (10), p.1243-50, 1996.

[3] JOSEPH, K.; THOMAS, S. \& PAVITHRAN, C. - Effect of chemical treatment on the tensile properties of short sisal fiber-reinforced polyethylene composites Polymer, v.37, p.5139, 1996.

[4] RODOlfo Jr., A.; NUNES, L.R.; ORMANJ, W. Tecnologia do PVC, São Paulo: ProEditores Associados Ltda / Braskem, 2002.

[5] ROE, P. J. \& ANSEL, M. P. Jute-Reinforced polyester Composites, Journal of Materials Science, v.20, p.117-127, 1985.

[6] NOTHENBERG, M., “Cresce o Interesse pelo Uso de Fibras Naturais”, Plástico Moderno, v.263, p. 6-15, 1996.

[7] MURHERJEE, P.S.; SATYANARAYANA, K.G. Structure and properties of some vegetable fibres, part 1. Sisal fibre. Journal of Materials science, v.19, p.3925-34, 1984. 
[8] CHAND, N.; TIWARI, R.K.; ROHATGI, P.K. Bibliography resource structure properties of natural cellulosic fibres --anaannotated bibliography, Journal of Material Science, v.23, p.381-7, 1988.

[9] GOLDSTEIN, I. S. Composition of biomass, Organic Chemicals from biomass, CRC Press - Boca Raton, Cap.2, p.9, 1981.

[10] WILSON, P.I. Sisal, Vol II. In Hard Fibres research series, num 8, Rome: FAO, 1971.

[11] ROWELL, R.M. In: Rowell RM, Shultz TP, Narayan R, editors. Emerging Technologies for materials \& chemicals for biomass, ACS Symposium Ser, 476, p.12, 1992.

[12] CHAND, N.; HASHIMI, S. Metals materials and process, v.5, p.51, 1993.

[13] SARKANSEN, K. \& LUDWUING, H. - Lignin occurrence, formation, structures and reactions. John Willy e Sons, 1971.

[14] VARGHESE, S. KURIAKOSE, B. \& THOMAS, S. Short sisal fibre reinforced natural rubber composites: high-energy radiation, thermal and ozone degradation. Polymer Degradation and Stability, v.44, p. 55-61, 1994.

[15] MARROQUIM, S. Associação brasileira da agroindústria do coco - Abrocado. Uso da fibra de coco e látex na engenharia automotiva. Memorial da CrinaLátex do Brasil, 1994.

[16] MEDINA, J.C. Plantas fibrosas da flora mundial. Instituto Agronômico Campinas - Brasil, p.01-21, 1959.

[17] MEYER, R. W. Polyester Moulding Compounds and Moulding Technology, Chapman \& Hall, New York, 1987.

[18] GORTHALA, R.; ROUX, J. A. \& VAUGHAN, J. G. Resin Flow, Cure 
and Heat-Transfer Analysis for Pultrusion Process, Journal of Composite Materials, v.6, No. 28, 1994.

[19] FELIX, J.M.; GATENHOLM, P., "The Nature of Adhesion in Composites of Modified Cellulose Fibers and Polypropylene", Journal of Applied Polymer Science, v. 42, p.609-620, 1991.

[20] CASTANO V.M.; MARTINEZ, L.; SANCHEZ, H. \& ARITA, I. "Preparation and Characterization of a Natural Fiber-polymer Resin Composite", Materials Letter, v.15, p.108-112, 1992.

[21] CHAND, N.; HASHMI, S.A.R., "Mechanical Properties of Sisal Fibre at Elevated Temperatures", Journal of Materials Science, v.28, p.6724-6728, 1993.

[22] ALMEIDA, J.R.M., "Fibre-Matrix Interface and Natural Fibre Composites", Journal of Materials Science Letters, v.2, p. 578-580, 1991.

[23] AGNELLI, JAM - Verbetes em polímeros. Apêndice 1.01 - UFScar, 1998.

[24] SERA, E.E.; ROBLES-Austriaco, L.; Pama, R.P., "Natural Fibers as Reinforcement", Journal of Ferrocement, v.20, p.109-124, 1990.

[25] JOly C, GaUthiER, R.; ESCOUBen, M. Journal of Applied Polymer Science, v.61, p.57, 1996.

[26] JOSEPH, P.V.; KURUVILLA, J.; THOMAS, S. Effect of processing variables on the mechanical properties of sisal-fiber-reinforced polypropylene composites. Composites Science and Technology, v.59, p.1625-1640, 1999.

[27] KLASON C, KUBAT J, GATENHOLM P. Wood fiber reinforced composites. In: Glasser WG, Hatakeyama $\mathrm{H}$, editors. Viscoelaticity of biomaterials. Washington: American Society, 1992. 
[28] GEETHAMMA, V.G.; MATHEW, K.T.; LAKSHMINARAYANAN, R.; THOMAS, S. Composite of short coir fibers and natural rubber: effect of chemical modification, loading and orientation of fiber. Polymer, v.39, p.148391, 1998.

[29] RONG, M.Z.; ZHANG, M.Q., LIU, Y.; YANG, G.C.; ZENG, H.M. The effect of fiber treatment on the mechanical properties of unidiretional sisal-reinforced epoxy composites. Composites Science and Technology, v.61,p.1437-1447, 2001.

[30] RAJ, R.G.; KOKTA, B.V. Reinforcing high density polyethylene with cellulose fibers. I: effect of additives on fiber dispersion and mechanical properties. Polymer Eng. and Science, v.31, p.1358-1362, 1991 ..

[31] WOODHAMES, R.T.; THOMAS, G.; RODGERS, D.K.; Wood fibers as reinforcing for polyolefins. Polymer Eng. and Science, v.24, p.1166-1171, 1984.

[32] CANCHÉ-ESCAMILLA, G.; GAUICH-CUPUL, J.I.; MENDIZÁBAL, E.; PUIG, J.E.; VÁSQUEZ-TORRES, H.; HERRERA-FRANCO, P.J. Mechanical Properties of acrylate-grafted henequen cellulose fibers and their application in composits. Composites, Part A : applied science and manufacturing, v.30, p.349-359, 1999 .

[33] OKSMAN, K. Mechanical Properties of Resin transfer molded Natural Fiber Composites, The Fifth International Conference on Wood-Fiber Plastics Composites, May 26-27,p.97-103, 1999.

[34] MANDAL, R. Aplication of Jute Fiber Composites: Thermoplastics and thermosets, The Fifth International Conference on Woodfiber-Plastic Composites, May 26-27, p.193-197, 1999. 
[35] NOTHENBERG, M. Cresce o Interesse pelo Uso de Fibras Naturais. Plástico Moderno, v.263, p.6-15, 1996.

[36] JOSEPH, K.; MATTOSO, L.H.C. Sisal Fibre Reinforced Polymer Composites: Status and Future. Natural Polymers and Composites, p.333-343, 2000.

[37] JOSEPH, K.R; MATTOSO, L.H.C.; TOLEDO, R.D.; THOMAS, S.; CARVALHO, L.H.; POTHEN, L.; KALA, S.; JAMES, B. Natural Fiber Reinforced Thermoplastic Composites, Natural Polymers and Agrofibers Based Composites, edited by Frollini, E.; Leão, A.; Mattoso, L.H.C., São Carlos: IQSC/USP, UNESP and Embrapa Instrumentação Agropecuária, p. 159-201, 2000.

[38] Li Y, Mai YW, Ye L. Sisal fibres and its composites : a review of recent developments. Composites Science and Technology, v.60, p. 2037-2055, 2000

[39] KURUVILlA, J.; VARGHESE, S.; KALAPRASSAD, G.; THOMAS, S.; PRASANNAKUMARI, L.; KOSHY, P.; PAVITHRAN, C. Influence of Interfacial Adhesion on the Mechanical Properties and Fracture Behavior of the Short Sisal Fibre Reinforced Polymer Composites, Eur. Polymer Journal, v.32, N. 10, p.1243-1250, 1996.

[40] SELZER, R., "Environmental Influences on the Bending Properties of Sisal Fiber Reinforced Polymer Composites", Advanced Composites Letters, v.4, p.87-90, 1995.

[41] CINTRA, J.S.F. Influência de Modelos de Orientação de Fibras Curtas nas Propriedades Físicas e Mecânicas de Termoplásticos Reforçados. Anais do $2^{\circ}$ Congresso Brasileiro de Polímeros, Rio de Janeiro, p.863 - 866, 1995

[42] ISMAIL, H.; ROSNAH, N.; ROZMAN, H. D., "Effects of Various Bonding 
Systems on Mechanical Properties of Oil Palm Fibre Reinforced Rubber Composites", European Polymer Journal, v.33 (8), p.1231-1238, 1997.

[43] GEETHAMMA, V.G.; JOSEPH, R.; THOMAS, S, "Short Coir FibreReinforced Natural Rubber composites: Effects of fiber Length, Orientation, and alkali Treatment", Journal of Applied Polymer Science, v.55, p.583-594, 1995.

[44] BLEDZKI, A.K.; REIHMANE, S., Gassan, J., "Properties and Modification Methods for Vegetable Fibers for Natural Fiber Composites", Journal of Applied Polymer Science, v.59, p.1329-1336, 1996.

[45] LEONARD, I. NASS. Calendering and calender laminating, Encyclopedia of PVC,Warren, New Jersey, v.3, cap.25, 1980.

[46] TESTER, D.A. Developments in PVC technology, (eds J. H. L. Henson and A.Whelan), Applied Science Publishers, london, Chapter 1, 1973.

[47] BRYDSON, J.A. Plastics Materials, Newnes-Butterworts, London p.248-9, 1975.

[48] TITOW, W.V. PVC technology- $4^{\text {th }}$ ed., Elsevier Applied Science Publishers, London and New York., 1984.

[49] DOOLITTLE, A.K. The technology of Solvents and Plasticizers, John Wiley, New York, Ch. 14 and 15, 1954.

[50] LEUCHS, D. Kunststoffe, v.46, p.547, 1956.

[51] WALTER, A.T. Journal of Polymer Science, v.9, p.207, 1965.

[52] PITA, V.J.R.R.; SAMPAIO, E.E.M.; MONTEIRO, E.E.C. Mechanical properties evaluation of PVC/Plasticizers and PVC/Thermoplastic polyurethane blends for extrusion process. Instituto de Macromoléculas, UFRJ, 2002. 
[53] Literatura Técnica DuPont, DuPont Modifiers Compounding PVC with Elvaloy, 2003.

[54] NETO, S.C. Caracterização físico-química de um poliuretano derivado de óleo de mamona utilizado para implantes ósseos. Tese de Doutorado, USP, São Carlos, 1997.

[55] KUMAR, R.P.; THOMAS, S. Tear and Processing Behaviour of Short Sisal Fibre Reinforced Styrene Butadiene Rubber Composites. Polymer International, v.38, p.173-182, 1995.

[56] YANG, C.G.; ZENG, H.M.; LI, J.J. The Study of Technology and Properties of Composites for Sisal Fibre reinforced PVC, Fibre Reinforced Plastics/Composites, v.6, p.22-26, 1995.

[57] MWAIKAMBO, L.Y; ANSELL, M.P. Chemical Modification of Hemp, Sisal, Jute, and Kapok Fibers by Alckalinization, Dep. of Engeneering Science, UK, 2001.

[58] PAIVA, J.M.F.; TRINDADE, W.G.; FROLLINI, E.; PARDINI, L.C. Carbon Materials from Sisal and Sugarcane Bagasse Reinforced Lignophenolic Matrices Composites, Natural Polymer and Composites IV, edited by Mattoso, L.C.H.; Leão, A.; Frollini, E., São Carlos: Embrapa Instrumentação agropecuária, UNESP, and IQSC/USP, p.416$421,2002$. 